\title{
Effect of nutritional deficiency on ruffed grouse condition and reproductive success
}

Aaron B. Proctor

West Virginia University

Follow this and additional works at: https://researchrepository.wvu.edu/etd

\section{Recommended Citation}

Proctor, Aaron B., "Effect of nutritional deficiency on ruffed grouse condition and reproductive success" (2010). Graduate Theses, Dissertations, and Problem Reports. 3014.

https://researchrepository.wvu.edu/etd/3014

This Thesis is protected by copyright and/or related rights. It has been brought to you by the The Research Repository @ WVU with permission from the rights-holder(s). You are free to use this Thesis in any way that is permitted by the copyright and related rights legislation that applies to your use. For other uses you must obtain permission from the rights-holder(s) directly, unless additional rights are indicated by a Creative Commons license in the record and/ or on the work itself. This Thesis has been accepted for inclusion in WVU Graduate Theses, Dissertations, and Problem Reports collection by an authorized administrator of The Research Repository @ WVU. For more information, please contact researchrepository@mail.wvu.edu. 


\section{EFFECT OF NUTRITIONAL DEFICIENCY ON RUFFED GROUSE CONDITION AND REPRODUCTIVE SUCCESS}

\section{AARON B. PROCTOR}

A Thesis Submitted to the Davis College of Agriculture, Natural Resources and Design at West Virginia University in Partial Fulfillment of the Requirements for the Degree of

\section{MASTER OF SCIENCE}

in

Wildlife and Fisheries Resources

Division of Forestry and Natural Resources

John W. Edwards, Ph.D., Chair

James T. Anderson, Ph.D.

Joseph S. Moritz III, Ph.D.

Morgantown, West Virginia

2010

Keywords: Appalachian Mountains, Bonasa umbellus, condition, food habits, nutrition, nutritional ecology, reproduction, ruffed grouse 


\title{
ABSTRACT \\ Effect of Nutritional Deficiency on Ruffed Grouse Condition and Reproductive Success
}

\begin{abstract}
Aaron B. Proctor
Maternal body fat condition (i.e., percent carcass fat) is often a focal point in determining reproductive success in female galliforms. Previous research has centered around habitat-related nutritional parameters affecting body condition and the influence on reproductive capacity. Past studies have shown that ruffed grouse (Bonasa umbellus) maintain higher mean body fat levels throughout the Appalachians and variation in body condition exceeds that found in northern grouse. In the Appalachians, ruffed grouse with diets devoid of energy-rich hard mast have lower body fat condition. It has been hypothesized that females in poorer condition will have lower productivity in the Appalachians. We conducted a 2-year study of captive Appalachian ruffed grouse (subspecies Bonasa umbellus monticola) to assess the effects of 4 treatment rations varying in dietary energy and crude protein on female body condition throughout the prebreeding and reproduction periods using total body electrical conductivity (TOBEC) technology. Females on low protein rations maintained higher carcass fat levels than females on high protein treatments, although high protein treatments led to less fat loss during reproduction. Highenergy rations produced females with higher fat levels prior to reproduction; however, adult females on high-energy treatments lost more fat during reproduction than low-energy treatments. We posit that the presence of low-protein, high-energy feed items in diets of Appalachian ruffed grouse potentially lead to higher percent body fat, whereas high-protein diets support leaner grouse. We also determined the effect of body fat condition on onset of laying, egg quality, clutch size, and chick mass at hatch. Our experimental treatment rations stratified females into differing fat condition classes, ranging from 3.9-43.5\% body fat. Although egg composition differed among condition classes, we found no evidence of a relation between fat condition and egg composition. Female grouse were capable of producing comparable eggs, clutches, and chicks across varying planes of body fat condition. Our results suggest that the effect of increased fat reserves in Appalachian ruffed grouse does not directly influence fecundity. We propose that any influence female condition has on fecundity and chick survival is enacted after the nesting effort is complete.
\end{abstract}




\section{ACKNOWLEDGMENTS}

I would first like to thank the Richard King Mellon Foundation for funding this study and for its generous support of the Appalachian Cooperative Grouse Research Project (ACGRP) as a whole. I also thank West Virginia University's Division of Forestry and Natural Resources, along with my committee chair and advisor, Dr. John Edwards. I also thank Dr. Joe Moritz and Dr. Jim Anderson for serving on my committee and their helpful insight throughout my time at WVU. Brent Sparks was my technician for 2.5 years and his help was invaluable. Our long hours at the "grouse house" were not without fun. Special thanks goes to Dr. Bob Cochrane for allowing the use of his ruffed grouse colony and his years of experience; his personal interest in and dedication to researching ruffed grouse in captivity is remarkable.

Professionally, I would like to thank Gary Norman for trusting in me to be a part of the ACGRP all the way from an inexperienced undergraduate technician to a contributing graduate student. His personal guidance and assistance throughout was a great resource. I thank all other cooperators and graduate students I knew along the way and for any help and advice they offered, for I was afforded a great deal of ruffed grouse knowledge from ACGRP graduate students before me. I thank Dr. Roy Kirkpatrick, Dr. Fred Servello, Dr. Sandy Middleton, Dr. Bill Giuliano, and Dr. Fred Brenner for their insightful discussion and advice during my research; all were very helpful due to their years of research and knowledge of game bird ecology.

I pause to issue a special thanks to Dr. George Seidel who passed away during the latter stages of this thesis. He was an invaluable asset to my research throughout the project design and analysis phases. Every graduate student would be lost without a good statistician, and George was always willing to offer his time with a smile. I also give a big thanks to Dave 
Steffen with the Virginia Department of Game and Inland Fisheries for his editorial assistance and statistical brilliance during final revisions of this thesis.

It would be impossible for me to not mention Pat Devers and the imprint he left. Pat helped me transition from a green undergraduate technician into an inquisitive and contributing graduate student. Aside from being a great mentor, I credit our times together for motivating me to tackle graduate school. Every young and eager wildlife student should have a Pat Devers around the campfire, not only for wildlife-related discussion, but life in general.

Personally, I first have to thank my family. My mom and dad always have and still give me full support in every endeavor of my life. Thanks also go to my little brother and sister for putting up with me before I left the nest. Special thanks go to Kit Ruesch, Joe Osbourne, Bridget Crokus, Garrett Staines, Jason Stolarski, Jon Niles, Sarah McClurg, Walter Veselka, Ken Sheehan, Lisa Tager, Kelly Perkins and the rest of my fellow graduate students in the Division for many fun times in Morgantown and lending an ear for me to gripe when necessary. Graduate school is what you make of it, and those I shared it with made it interesting and memorable. Special thanks goes to Sheldon Owen, Mary Beth Manjerovic, and Tamara Terry for "showing me the ropes" and getting me upright upon my arrival at WVU. 


\section{TABLE OF CONTENTS}

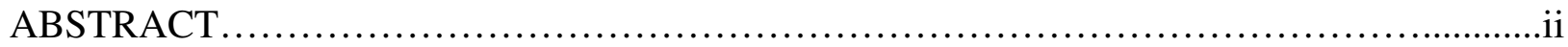

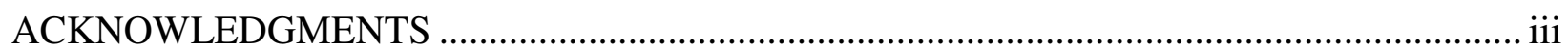

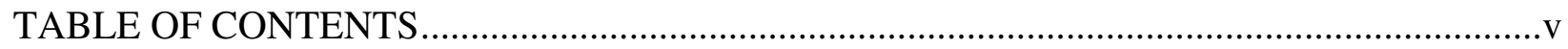

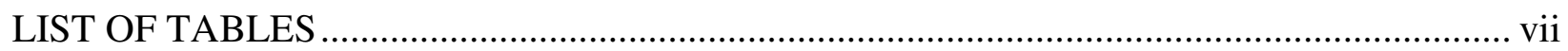

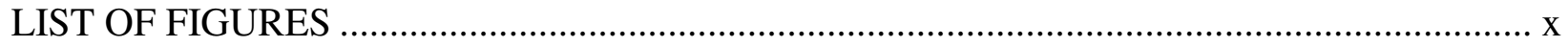

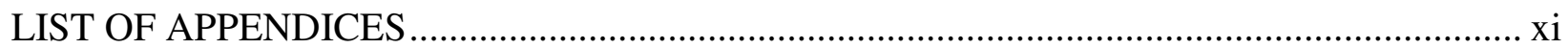

CHAPTER 1 - INTRODUCTION, JUSTIFICATION, AND RESEARCH OBJECTIVES ...........1

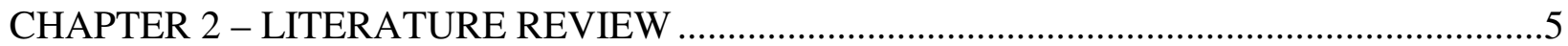

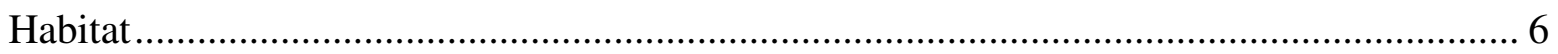

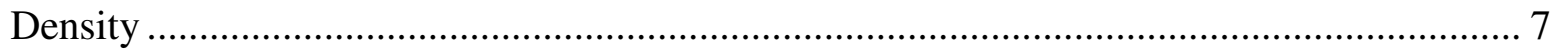

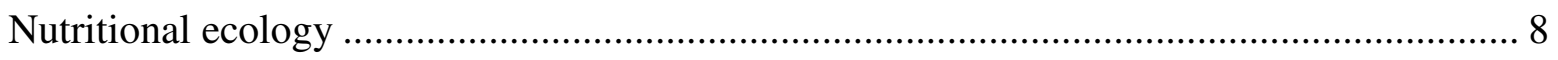

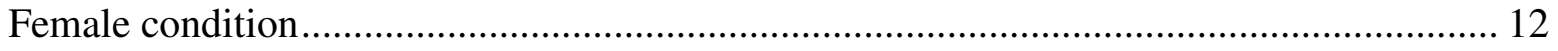

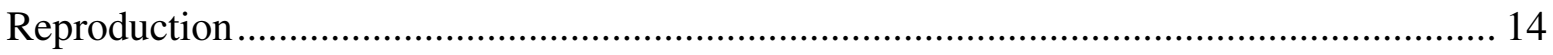

CHAPTER 3 - EFFECT OF NUTRITIONAL DEFICIENCY ON CONDITION OF FEMALE

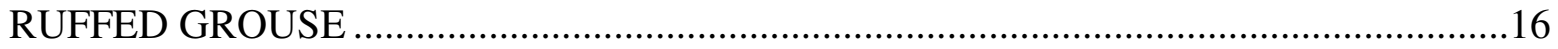

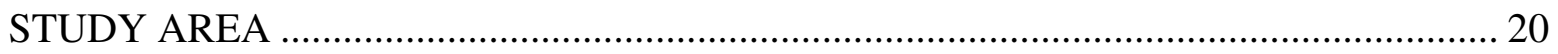

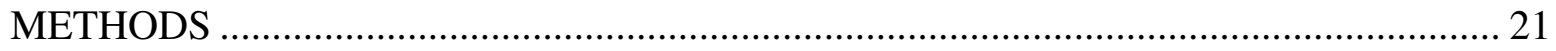

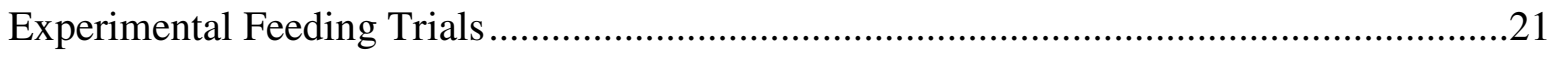

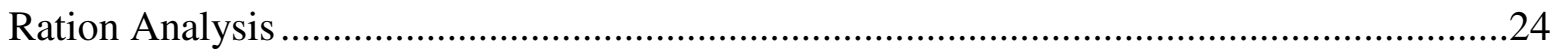

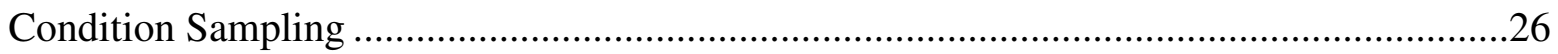

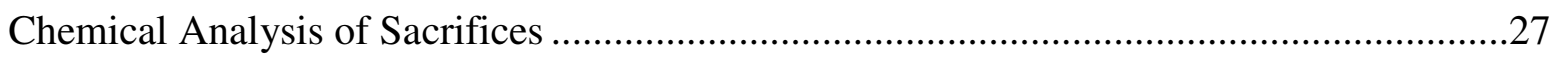

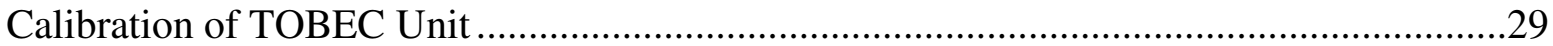




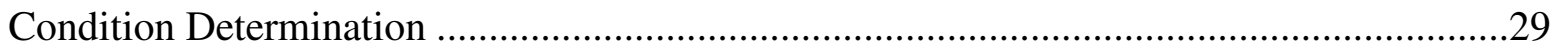

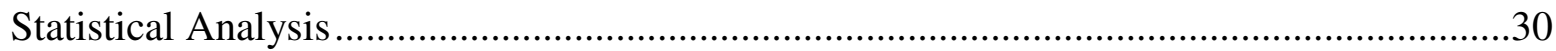

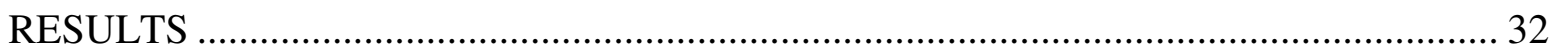

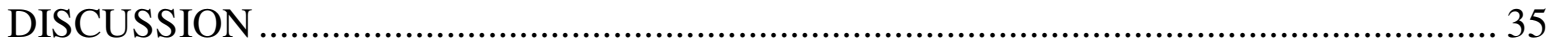

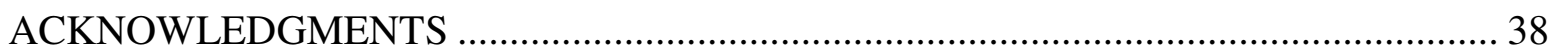

CHAPTER 4 - EFFECTS OF FAT CONDITION ON FECUNDITY IN RUFFED GROUSE...39

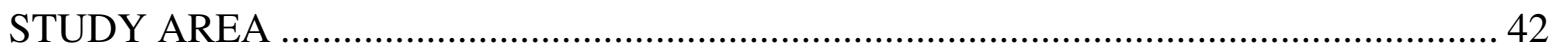

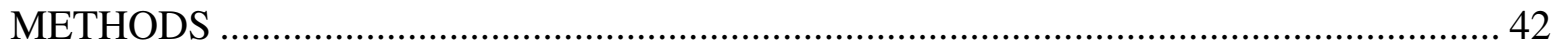

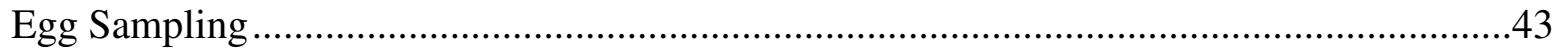

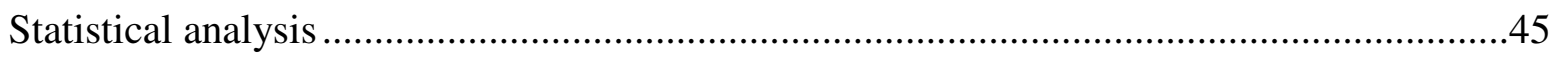

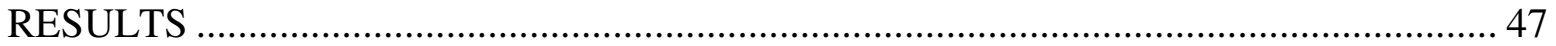

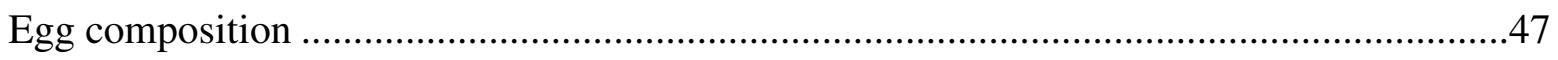

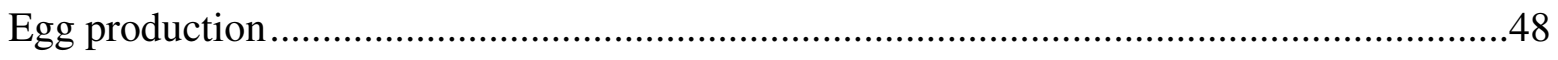

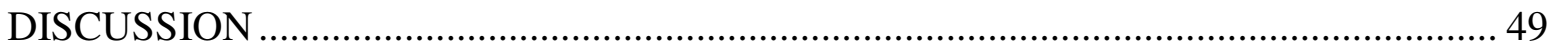

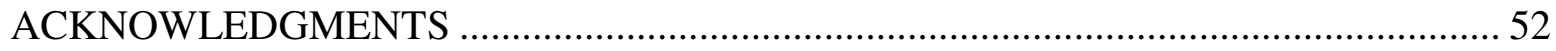

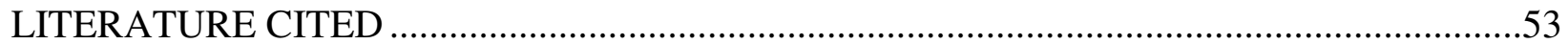




\section{LIST OF TABLES}

Table 3.1. Composition (\%) of treatment rations used in 2004 and 2005 trials. Nitrogencorrected apparent metabolizable energy $\left(\mathrm{AME}_{\mathrm{N}}\right.$ in $\mathrm{kcal} / \mathrm{g}$; mean $\left.\pm \mathrm{SE}\right)$ is both combined and divided into age classes. Crude protein (g) values are based on average daily intake (15.6-25.4 g) of the control group throughout the study, represent combined age classes, and are based on lab-derived determinations for each ration. We conducted our condition study of captive ruffed grouse at the West Virginia University Animal Science Farm, 20042005

Table 3.2. Variables used to assess and model condition of captive female ruffed grouse at the West Virginia University Animal Science Farm, 2004-2005.

Table 3.3. One-way ANOVA for change in pre-laying fat (\%) as a condition metric in captive grouse at the West Virginia University Animal Science Farm 2004-2005.

Table 3.4. Change in pre-laying fat $(\%$; mean \pm SE) among treatment groups of female ruffed grouse at West Virginia University’s Animal Science Farm 2004-2005.

Table 3.5. One-way ANOVA for laying fat (\%) as a condition metric in captive grouse at the West Virginia University Animal Science Farm, 2004-2005. .70

Table 3.6. Laying fat (\%; mean \pm SE) among treatment groups of female ruffed grouse at West Virginia University’s Animal Science Farm, 2004-2005.

Table 3.7. One-way ANOVA for change in fat (\%) during reproduction as a condition metric in captive grouse at West University Animal Research Farm, 2004-2005.

Table 3.8. Change in fat during reproduction (\%; mean $\pm \mathrm{SE}$ ) among treatment groups of female ruffed grouse at West Virginia University's Animal Science Farm, 2004-2005. 
Table 3.9. One-way ANOVA for post-laying percent fat (\%) of captive grouse 2-weeks after termination of laying at West University Animal Research Farm, 2004-2005.

Table 3.10. Post-laying fat (\%; mean \pm SE) of female ruffed grouse at West Virginia University's Animal Sciences Farm, 2004-2005. 75

Table 3.11. One-way ANOVA for pre-laying body mass (g) at onset of laying in captive grouse at West University Animal Research Farm, 2004-2005.

Table 3.12. Treatment effect on pre-laying body mass ( $\mathrm{g}$; mean $\pm \mathrm{SE}$ ) of female ruffed grouse at West Virginia University’s Animal Science Farm, 2004-2005.

Table 4.1. Independent and dependent variables used to assess female ruffed grouse condition and reproduction at West Virginia University Animal Sciences Farm 2004-2005.

Table 4.2. One-way ANOVA for intraclutch variation in egg composition (nested by female) tested using percent body fat as a condition metric in captive female ruffed grouse at the West Virginia University Animal Sciences Farm 2004-2005. For 2004, first, middle, and last-laid eggs were used. For 2005, first and sixth-laid eggs were used in analysis. Values can be found in Table 4.3

Table 4.3. Mean mass, percent protein, and percent fat of eggs tested with one-way ANOVA using percent body fat as a condition metric in captive female ruffed grouse at the West Virginia University Animal Sciences Farm 2004-2005. Body fat is a range (\%). Clutch egg is sequential egg position within clutch.

Table 4.4. One-way ANOVA for variation in first egg composition in 2004 tested using percent body fat condition as a condition metric in captive female ruffed grouse at the West Virginia University Animal Sciences Farm 2004-2005. Values can be found in Table 4.3.83 
Table 4.5. One-way ANOVA for variation in first egg composition between 2004 and 2005 tested using percent body fat condition as a condition metric in captive female ruffed grouse at the West Virginia University Animal Sciences Farm 2004-2005. Values can be found in Table 4.3. .84

Table 4.6. One-way ANOVA for variation in egg composition of first and sixth-clutch eggs across independent parameters in 2005 tested using percent body fat condition as a condition metric in captive female ruffed grouse at the West Virginia University Animal Sciences Farm 2004-2005. Values can be found in Table 4.3.

Table 4.7. One-way ANOVA for egg production and mean chick hatch mass per female tested using percent body fat condition as a condition metric in captive female ruffed grouse at the West Virginia University Animal Sciences Farm 2004-2005. Year was a fixed parameter in

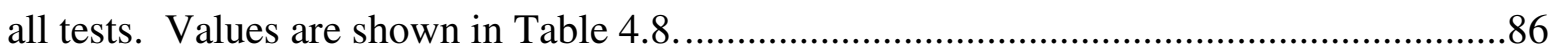

Table 4.8. Values (mean \pm standard error) for ruffed grouse reproduction parameters at West Virginia University Animal Sciences Farm 2004-2005. Laying fat is a range (\%). Egg mass $(\mathrm{g})$ and chick hatch mass $(\mathrm{g})$ were averaged per female $(n)$ prior to analysis. 


\section{LIST OF FIGURES}

Figure 1.1. Range and overlap of aspen (Populus spp.) and ruffed grouse (Bonasa umbellus) in North America. Range of ruffed grouse subspecies within northern range $(\mathrm{C}=\mathrm{Canadian}[\mathrm{B}$. u. togata $], \mathrm{E}=$ eastern $[$ B. u. umbellus $])$ and the Appalachian region $(\mathrm{A}=$ Appalachian $[B$.

u. monticola])

Figure 3.1. Mean daily feed intake of the control treatment group and amount fed to fixedtreatment groups (HE-LP, LE-HP, LE-MP) from February 1 until the termination of reproduction at West Virginia University's Animal Sciences Farm, 2004-2005. Vertical line denotes onset of laying in both years (approximately 10 weeks). 


\section{LIST OF APPENDICES}

Appendix A. Nutritive values of select food items from previous ruffed grouse field studies.

Appendix B. Cage layout and treatment assignments within the ruffed grouse facility for the 2004 and 2005 experiments. Cages are arranged in 4 rows, stacked top to bottom, 2 cages high and 12 across. Treatment rations are shown at the top of each block (HE-LP = High energy-low protein; LE-HP = Low energy-high protein; LE$\mathrm{MP}=$ low energy-medium protein). $\mathrm{A}=$ adult female, $\mathrm{J}=$ juvenile female.

Appendix C. Candidate models for estimating percent fat based on analysis of sacrificed grouse ( $n=16$ individuals). Data were fit using linear regression in SAS (PROC REG, SAS Institute Inc. 2002-2004). .92

Appendix D. Validation of best models for fat mass (g) and percent carcass fat on an independent sample of female ruffed grouse $(n=10)$. Differences between actual and predicted values are absolute. Body mass (g) values were recorded immediately before final TOBEC sampling and sacrifice.

Appendix E. Egg parameters (mean \pm SE) by year, percent body fat, age class, and clutch egg taken at West Virginia University Animal Sciences Farm 2004-2005. Percent body fat is a range. Egg mass and shell mass are in grams. Moisture, protein, and fat are percentages

Appendix F. Representation of experimental design with regards to ration, condition assessment, and sampling periods. Sample periods taken every 14 days. Post-laying fat (not shown) was assessed 14 days after sample period 12. 


\section{CHAPTER 1 - INTRODUCTION, JUSTIFICATION, AND RESEARCH OBJECTIVES}

Ruffed grouse (Bonasa umbellus) are the most widely distributed upland game bird in North America (Bump et al. 1947). Their range extends from Alaska south to California, and throughout the Rocky Mountains, including portions of Utah, Wyoming, Idaho, and Montana. In eastern North America they are found from Labrador in Canada to British Columbia, and from Minnesota east through the New England states and south through the central and southern Appalachians into northern Georgia (Bump et al. 1947, Aldrich 1963, Gullion 1977, Johnsgard 1983, Rusch et al. 2000; Figure 1.1). The ruffed grouse's northern range includes the Great Lake states into southeastern Canada, where the eastern (B. u. umbellus) and Canadian (B. u. togata) subspecies are found (Figure 1.1). The southern range extends throughout the central and southern Appalachians into northern Georgia and is occupied by the Appalachian subspecies (B. u. monticola) (Figure 1.1).

Historically, ruffed grouse densities are lower in the Appalachians than in the northern range (Servello and Kirkpatrick 1989a). Bump et al. (1947:559) reported densities in the Adirondacks of New York to range from 7-22 grouse/100 ha. Gullion (1977) reported densities ranging from 41-83 grouse/100 ha in prime habitat in Minnesota. Although thought to be stable, grouse populations in the northern range fluctuate from low to high densities over an approximate 10-year cycle (Rusch 1989). In the southern range, Weber and Barick (1963) reported densities of 7-10 grouse/100 ha in western North Carolina. Observational evidence suggests that over the past few decades densities in the southern range have declined. USGS Breeding Bird Survey data from 1966-2005 indicates a 5\% annual decline in ruffed grouse populations in the Appalachian region (Sauer et al. 2006). 
Although most grouse research has originated in northern populations, researchers have recently focused on the southern range and potential factors for the perceived populations declines reported in this region. Results from the Appalachian Cooperative Grouse Research Project (ACGRP), a 6-year study initiated in 1996 to investigate the decline of ruffed grouse populations in the central and southern Appalachians, suggested female nutrition and body condition as possible factors for declining densities (Long et al. 2004a).

In the northern range ruffed grouse are primarily associated with aspen (Populus spp.; Figure 1.1) and consume a preponderance of aspen buds and catkins that are nutrient rich and abundant year-round (Bump et al. 1947, Svoboda and Gullion 1972, Gullion 1977, Servello and Kirkpatrick 1987, Barber et al. 1989, Hewitt and Kirkpatrick 1996). In contrast, grouse diets are more varied throughout the central and southern Appalachians where aspen is sparse to absent, and high-quality nutrition may be scarce during poor mast years (Servello and Kirkpatrick 1988, Long et al. 2004). When available, hard and soft mast are primary food items in fall and winter throughout the Appalachians; herbaceous leaves make up the bulk of the grouse diet in spring (Norman and Kirkpatrick 1984, Long et al. 2004b). Long et al. (2004b) reported grouse crops collected in spring (March and April) contained 26\% oak (Quercus spp.) and beech (Fagus sp.) mast, which remained available following a good mast crop the previous fall. In the absence of hard mast in the southern range, grouse consume evergreen leaves, which are high in phenolic compounds that compromise nutrient absorption (Hewitt and Kirkpatrick 1997b). Long et al. (2004b) reported evergreen leaves in $36 \%$ of grouse crops collected in the southern range, and found evidence that mountain laurel was an alternate food source when acorns were unavailable, with mountain laurel having the highest importance value among food items on 3 of 8 ACGRP study sites. Consumption of such poor-quality diets when hard mast is unavailable may lead to 
seasonal nutritional deficiency in Appalachian ruffed grouse (Servello and Kirkpatrick 1987, Hewitt and Kirkpatrick 1997b, Long et al. 2004b).

Thomas et al. (1975) reported that ruffed grouse in Ontario, Canada maintain low carcass fat levels (5.9-9.3\%) year-round and hypothesized that in the northern range grouse feed frequently to maintain basal metabolic energy requirements. Long et al. (2004a) reported that ruffed grouse collected in Michigan, Wisconsin, and Minnesota during April had lower carcass fat levels than grouse collected in the central and southern Appalachians during the same period $(6.0 \pm 0.4 \%$ [mean $\pm \mathrm{SE}$ ] vs. $10.8 \pm 0.4 \%$, respectively). It has been hypothesized that grouse in the northern range can more easily meet their nutritional requirements due to the year-round availability of aspen catkins and buds, and therefore maintaining higher fat reserves does not provide a selective benefit (Svoboda and Gullion 1972, Gullion 1977, Servello and Kirkpatrick 1987, Long et al. 2004b). Whereas, grouse in the southern range are more vulnerable to local mast failures and in the absence of a reliable food source (i.e., aspen) will attain relatively higher mean carcass fat levels (i.e., stored energy) when resources are available to increase survival and reproductive success. Long et al. (2004a) reported that when hard mast was present in crops of pre-laying female ruffed grouse collected in the Appalachians, percent body fat averaged 20.0\% compared to $11.7 \%$ in grouse whose crops were devoid of hard mast. Moreover, chick survival to 5 weeks post-hatch in the Appalachians was higher where females had moderate $(37 \%$ survival) and high (26\% survival) levels of carcass fat compared to females with lower fat levels (13\% survival; Long et al. 2004a). Devers and Stauffer (2004) found a positive correlation between chick survival and hard mast production the previous fall in the Appalachians, suggesting a possible link between female fat condition and productivity. 
Determining the relation between female condition and reproductive success in wild ruffed grouse would be challenging, if not impossible. In an experimental study of captive ruffed grouse in Ontario, Canada, Beckerton and Middleton (1982) reported increases in rate and duration of laying, first egg mass, mean egg mass, clutch size, clutch mass, chick mass at hatch, and chick survival to 9 weeks with increased protein content in test rations. Although their study represents the only experimentally controlled investigation of nutrition and productivity in ruffed grouse, it did not examine the effects of nutrition on body condition or body condition on productivity.

To further test the hypothesis that productivity is related to pre-laying condition, I maintained captive female ruffed grouse on rations differing in dietary energy and crude protein content to experimentally determine the effect of nutritional deficiency on female body condition and reproductive success. Specific objectives and hypotheses of my study included:

(1) Assess the effect of dietary energy and crude protein on female ruffed grouse prebreeding condition:

(H1) Females fed a ration higher in dietary energy and protein will maintain higher carcass fat levels relative to females on deficient rations.

(H2) Percent carcass fat in females will vary more than percent lean body mass.

(2) Determine the relation of body condition of female ruffed grouse and clutch initiation, egg production, egg composition, and chick mass at hatch:

(H1) Females with higher percent carcass fat will produce higher quality eggs (\% egg protein and fat), larger clutches, and larger chick mass at hatch.

(H2) Females with higher pre-laying percent carcass fat will have higher post-laying fat reserves compared to females with lower pre-laying percent carcass fat. 


\section{CHAPTER 2 - LITERATURE REVIEW}

Ruffed grouse (Bonasa umbellus) are the most widely distributed upland game bird in North America (Bump et al. 1947). They are typically known by a ruff of erectable feathers around the neck, and for the behavior of males that "drum" on logs to attract females and defend territory. Their range extends from Alaska south to California, and throughout the Rocky Mountains, including portions of Utah, Wyoming, Idaho, and Montana. In eastern North America they are found from Labrador in Canada to British Columbia, and from Minnesota east through the New England states and south through the central and southern Appalachians into northern Georgia (Bump et al. 1947, Aldrich 1963, Gullion 1977, Johnsgard 1983, Rusch et al. 2000; see Chapter 1 Figure 1.1).

Ruffed grouse are one of 16 species of grouse that are characterized as predominantly ground-dwelling and chicken-like in morphology (Johnsgard 1983). Grouse are in the order Galliformes and comprise the family Tetraonidae. Ruffed grouse share the genus Bonasa with the Eurasian hazel grouse (B. bonasia) and black-breasted hazel grouse of China (B. severzowi). Johnsgard (1983) describes 11 subspecies of ruffed grouse in North America that are classified primarily by geographic region, whereas Runkles (1989) recognizes 12 subspecies. The Canadian (B. u. togata) and eastern (B. u. umbellus) subspecies are found in the northern portion of the range from the Lake States into southeastern Canada (see Chapter 1 Figure 1.1; Johnsgard 1983). Ruffed grouse in the Appalachian region are of the subspecies B. u. monticola, for "mountain dwelling" grouse, and range from extreme southeastern Michigan through the southern portion of Ontario east through Pennsylvania and south through the Appalachian's of eastern Ohio, West Virginia, Virginia, and mountain regions of North Carolina, Tennessee, Kentucky, and northern Georgia (see Chapter 1 Figure 1.1; Johnsgard 1983, Runkles 1989). 


\section{Habitat}

Throughout the range, ruffed grouse inhabit primarily early successional upland deciduous forests with high stem densities, a mid-story component, and herbaceous ground cover (Bump et al. 1947, Edminster 1947). Ruffed grouse in their northern range are primarily associated with aspen (Populus spp;; see Chapter 1 Figure 1.1). Aspen regeneration with stem densities $>14,000$ stems/ha and stem height $>5 \mathrm{~m}$ is considered prime drumming habitat (Thompson and Fritzell 1988, Barber et al. 1989b). Conifers mixed within aspen stands are desirable, as they provide thermal cover for roosting ruffed grouse during storms and in winter (Barber et al. 1989b). Snow roosting, the practice of burrowing under snow to reduce convectional heat loss is often observed in the northern range where snowfall is ample and more persistent (Bump et al. 1947, Edminster 1947, Gullion 1970, Gullion and Svoboda 1972).

Aspen is sparse to absent in the ruffed grouse's southern range of central and southern Appalachians. Ruffed grouse here are found in two primary forest types: oak-hickory and mixed-mesophytic forests (Whitaker et al. 2004, Whitaker et al. 2007). Appalachian ruffed grouse have similar habitat requirements as ruffed grouse in the northern range, but meet these requirements within different vegetative types. Evergreen shrubs such as mountain laurel (Kalmia latifolia) and great rhododendron (Rhododendron maximum) provide grouse overhead protection and thermal cover in winter (Barber et al. 1989b). Tree species such as hickory (Carya spp.), oak (Quercus spp.), birch (Betula spp.), and cherry (Prunus spp.) replace the missing aspen component in southern grouse range (Whitaker et al. 2007). Snow roosting is an infrequent behavior in the Appalachians. Whitaker (2003) reported that in the absence of ample snow ruffed grouse showed no preference for roost microsite type, but were frequently found 
ground roosting in fallen oak leaves that likely provide sufficient thermal cover in the southern range.

Ruffed grouse nests are crude and bowl-shaped, and usually constructed in leaf litter at the base of a tree, stump, log, fallen branch, or rock (Larson et al. 2003). Barber et al. (1989b) describes nesting habitat as fairly open at ground level, with tree stems $5-13 \mathrm{~cm}$ in diameter under a well developed overstory canopy. In both the ruffed grouse's northern range and throughout the Appalachians, brood cover is defined as containing mature herbaceous ground cover and a well-developed canopy to protect chicks from avian predators (Barber et al. 1989b, Haulton 1999, Jones et al. 2008, Tirpak et al. 2008).

\section{Density}

Historically, ruffed grouse densities have been lower in the Appalachians than in the northern range (Gullion 1977, Rusch and DeStefano 1989, Servello and Kirkpatrick 1989a). Bump et al. (1947:559) reported densities in the Adirondacks of New York to range from 7-22 grouse/100 ha. Densities range from 41-83 grouse/100 ha in prime habitat in Minnesota (Gullion 1977). In the extreme southern range densities of 7-10 grouse/100 ha have been reported in western North Carolina (Weber and Barick 1963). In the northern range densities are reported to fluctuate in approximately 10-year cycles (Rusch 1989); however, populations are generally considered stable given their cyclic behavior. Anecdotal evidence suggests that over the past few decades densities in the southern range have declined. USGS Breeding Bird Survey data from 19662005 indicates a 5\% annual decline in ruffed grouse populations in the Appalachian region (Sauer et al. 2006). It has been suggested that this decline as well as historic differences in population densities of grouse between the northern range and Appalachian region are ultimately habitat related, and largely the result of differences in nutritional ecology. 


\section{Nutritional ecology}

Dietary energy and protein._- Galliformes eat to satisfy basal energy requirements and protein deficiencies are not believed to lead to increased food consumption (Nestler 1944, Hill and Dansky 1954, Cain et al. 1963, Barrett 1969, National Research Council 1984, Giuliano et al. 1996). Bobwhite (Colinus virginianus) and scaled quail (Callipepla squamata) increase consumption of energy-poor foods to meet daily energy requirements, and eat to fulfill daily energy requirements when on ad libitum feed in captivity (Cain et al. 1963, Giuliano et al. 1996). Energy deficiency in female galliforms results in egg-laying delay, ovarian degeneration, and reduced egg production (King 1973).

Although energy is often considered the primary dietary parameter that determines the amount of feed consumed in galliforms, dietary protein also is important in physiological processes (Scott 1973; Allen and Young 1980; Beckerton and Middleton 1982, 1983; National Research Council 1984; Underwood et al. 1991; Koutsos et al. 2001). Dietary protein is essential in supporting nitrogen needs for tissue growth and maintenance, feather growth, and reproductive processes in birds (Koutsos et al. 2001). Protein deficiency or even a single amino acid deficiency can suppress growth in birds and cause a loss of body mass (Scott 1973, Allen and Young 1980, National Research Council 1984, Koutsos et al. 2001). Beckerton and Middleton (1983) reported that as the level of dietary crude protein decreased there was a corresponding curvilinear decrease in protein:calorie ratio in captive ruffed grouse.

Protein:calorie ratios in wild ruffed grouse in the southern range have been reported lower than the northern range, resulting from diets having increasingly lower dietary protein from north to south (Servello and Kirkpatrick 1987). 
Dietary energy and protein can have substantial effects on reproduction in galliforms (Breitenbach et al. 1963, Beckerton and Middleton 1982, Giuliano et al. 1996). In an experimental study of ring-necked pheasant (Phasianus colchicus) in Wisconsin, Breitenbach et al. (1963) reported birds fed low protein rations maintained body mass until early in the reproductive season and then declined. Egg laying in females on low protein rations was depressed (9\% lower than control birds), but eggs were of normal composition and fertile. Beckerton and Middleton (1982) provided 5 isocaloric rations varying in protein content (7.6, $11.5,13.6,17.0$, and $20.1 \%$ ) to captive ruffed grouse in Ontario, Canada, and found that increases in protein content were associated with linear increases in rate and duration of laying, clutch size, mean egg mass, clutch mass, mean chick mass at hatch, and chick survival to 9 weeks. Beckerton and Middleton $(1982,1983)$ reported females on lower protein rations lost more mass during laying, and suggested that female ruffed grouse on a protein deficient diet may produce lower quality eggs (lower protein and overall mass), which could negatively influence hatching and chick survival. In Texas, Giuliano et al. (1996) studied the effects of different dietary energy and protein levels on reproductive success in captive bobwhite quail and scaled quail. They reported that during laying, females fed energy-deficient rations lost more body mass than females fed protein-deficient rations, suggesting that dietary energy may be more important in maintaining body mass than protein. In their study, energy-restricted rations negatively affected egg production in both species more so than protein-restricted rations (Giuliano et al. 1996). However, egg mass was not affected by dietary energy or protein, suggesting that quail invest all available reserves into making viable eggs, which concurs with the conclusions of Breitenbach et al. (1963). 
Food habits. - Throughout their range, ruffed grouse consume a wide variety of food items (Bump et al. 1947, Stoll et al. 1980, Seehorn et al. 1981, Thompson and Fritzell 1986, Servello and Kirkpatrick 1987). Ruffed grouse in New York are reported to eat twigs, buds, leaves, flowers, fruits, and seeds from 330 different plant and tree species (Bump et al. 1947). In Ohio, Stoll et al. (1980) found a total of 109 plant and invertebrate species in crops, fecal droppings, and digestive tracts of adult ruffed grouse and chicks. In Missouri, ruffed grouse crops collected during fall contained 23 species of plants, with wild grape (Vitis spp.) being the most common (Thompson and Fritzell 1986). Buds, twigs, and catkins make up the bulk of winter diets of ruffed grouse in New York, Wisconsin, Maine, and Washington (Servello and Kirkpatrick 1987). In the southern range, Seehorn et al. (1981) reported over 34 woody and herbaceous plant species in crops and gizzards of ruffed grouse collected in southwestern Virginia, western North Carolina, and northern Georgia. Soft fruits have been found in 40-90\% of winter crop contents in Georgia, North Carolina, and Virginia, and Indiana; and buds and twigs of cherry and birch were found in $>50 \%$ of winter crop contents in West Virginia (Servello and Kirkpatrick 1987). Nutritional ecology studies of ruffed grouse have shown that habitats and associated nutritional conditions within the southern range differ markedly from the northern range where ruffed grouse are primarily aspen-dependent (Servello and Kirkpatrick 1987, Long et al. 2004b). Ruffed grouse in oak-hickory forests in the Appalachians select for acorns in fall and winter when available (Servello and Kirkpatrick 1987, 1988; Long et al. 2004b). Servello and Kirkpatrick (1988) found acorns to comprise $60 \%$ of crop contents following an exceptional acorn crop. During periods of low mast production, it has been hypothesized that ruffed grouse must spend more time foraging on lower-quality foods to meet basal energy requirements (Norman and Kirkpatrick 1984, Servello and Kirkpatrick 1987, Hewitt and Kirkpatrick 1997a). 
When high-quality food items are limited or absent during winter, ruffed grouse alternately consume evergreen species such as mountain laurel (Stafford and Dimmick 1979, Servello and Kirkpatrick 1987, Long et al. 2004b). During winter, ruffed grouse in the southern Appalachians consume substantial quantities of greenbrier (Smilax sp;; $20 \%$ of diet), mountain laurel (15\%), and Christmas hollyfern (Polystichum acrostichoides; 11\%) (Stafford and Dimmick 1979). In the Appalachian region, Long et al. (2004b) reported evergreen leaves in 36\% of grouse crops, and found evidence that mountain laurel was eaten in the absence of acorns.

Evergreen leaves are higher in total phenols and tannins than most other ruffed grouse foods (Appendix A). Overall effects of phenols and tannins are largely unknown, but are suspected to decrease palatability and nutrient absorption (Servello and Kirkpatrick 1987, 1989b; Hewitt and Kirkpatrick 1997b). Hewitt and Kirkpatrick (1997b) fed captive female ruffed grouse 2 experimental diets containing $20 \%$ and $40 \%$ mixtures, respectively, of mountain laurel and Christmas hollyfern. Females fed $20 \%$ evergreen rations showed no significant decrease in feed intake, whereas females fed $40 \%$ evergreen rations showed reduced intake rates, and could not maintain pre-study body mass.

Diets of grouse collected from March-April in the Appalachians differed substantially from grouse collected in the northern range during the same time period (Long 2007). Soft and hard mast are preferred by ruffed grouse throughout southwestern Virginia from July through December; whereas, from January through April grouse select herbaceous plants (Norman and Kirkpatrick 1984). In the northern range, grouse crops contained $46 \%$ aspen flower buds during the pre-breeding period, whereas crops collected from the Appalachians contained $<1 \%$ aspen flower buds (Long 2007). Long et al. (2004b) reported that during the pre-breeding period evergreen leaves, ferns, acorns, beechnuts (Fagus sp.), and soft mast were more prevalent in 
crops of Appalachian grouse than in the northern range. Higher ruffed grouse densities in the northern range are often attributed to the predominance of aspen, which provides a nutritious and readily available year-round food source of buds and catkins (Bump et al. 1947, Svoboda and Gullion 1972, Gullion 1977, Servello and Kirkpatrick 1987, Barber et al. 1989, Hewitt and Kirkpatrick 1996). In the northern range, ruffed grouse can easily meet their daily food requirements by foraging for short periods in the morning and evening, thus reducing risk of predation and overall energy expenditure (Svoboda and Gullion 1972; Doerr et al. 1974; Huempfner and Tester 1988; Hewitt and Kirkpatrick 1996).

\section{Female condition}

Past studies have examined body condition as a possible factor affecting reproductive success in female galliforms (Breitenbach et al. 1963, Beckerton and Middleton 1983, Giuliano et al. 1996). In the southern range of ruffed grouse, it has been hypothesized that lower availability of fruits and herbaceous leaves in late winter may increase consumption of evergreen leaves and negatively affect breeding condition of female ruffed grouse and consequently population densities (Norman and Kirkpatrick 1984, Servello and Kirkpatrick 1987, Hewitt 1994, Long et al. 2004a). Johnson et al. (1985) reported that carcass fat (lipid) levels are the most important factor in determining overall year-round body condition in birds based on their research on sandhill cranes (Grus canadensis) and greater white-fronted geese (Anser albifrons).

Carcass fat also has been a focus in past studies of tetraonid physiology (Irving et al. 1967, West and Meng 1968). Willow ptarmigan (Lagopus lagopus) in Alaska maintain low body fat levels year-round (Irving et al. 1967, West and Meng 1968). Irving et al. (1967) suggested that willow ptarmigan maintain themselves energetically by intensive feeding during evening hours, high metabolic rates for body heat, and dense feather insulation. 
Fat condition in ruffed grouse differs between populations in the northern and southern ranges (Thomas et al. 1975, Servello and Kirkpatrick 1987b, Long 2006). Similar to willow ptarmigan, Thomas et al. (1975) found captive grouse in Ontario, Canada maintained low carcass fat year-round (5.9-9.3\%), and hypothesized that grouse in the northern range must feed frequently to maintain basal metabolic energy. They estimated that complete fat catabolism in an average 600 -g ruffed grouse with $7.2 \%$ carcass fat would provide maintenance energy for only 2 days in a fasted state. Long (2006) reported mean pre-breeding carcass fat values of 6.7$7.9 \%$ in the northern range states of Minnesota, Wisconsin, and Michigan. Pre-breeding carcass fat for female ruffed grouse in the central and southern Appalachians ranges from 4.8-28.3\% (Norman and Kirkpatrick 1984; Servello and Kirkpatrick 1987, 1988; Long 2007), where years of exceptionally high fat levels have been found to follow a fall of high mast yield. Pre-breeding carcass fat levels in southwestern Virginia were reported higher the year after a exceptional acorn mast crop (22.4\% vs. $\leq 20.0 \%$, respectively; Servello and Kirkpatrick 1988). Throughout the Appalachians, ruffed grouse with crops containing hard mast averaged $20.0 \%$ carcass fat during the pre-breeding period compared to $11.7 \%$ in grouse with crops devoid of hard mast (Long et al. 2004a). Servello and Kirkpatrick (1987) and Long et al. (2004b) reported a negative relation in the occurrence of hard mast and evergreen leaves in crops of central and southern Appalachian grouse, indicating that ruffed grouse forage on nutritionally-poor evergreen leaves in the absence of hard mast. Although female ruffed grouse in the southern range often possess greater carcass fat reserves than in the northern range, carcass fat levels in the southern range are highly variable and mast dependent.

In the central and southern Appalachians, Long (2007) reported increased chick survival to 3- and 5-weeks post-hatch in females with $\geq 11 \%$ carcass fat. Long et al. (2004a) also reported 
increased chick survival on sites with females in moderate and high fat condition compared to sites with females in low fat condition (37 and $26 \%$ vs. $13 \%$, respectively).

\section{Reproduction}

Ruffed grouse are polygamous seasonal breeders and reach sexual maturity at 10 months of age (Bump et al. 1947, Edminster 1947). In New York, Bump et al. (1947) reported that nearly all females breed each spring. Average clutch size in the northern range is $>11$ eggs for first nest attempts (Bump et al. 1947, Edminster 1947, Cringan 1970). Clutch size for first nests in Virginia and West Virginia averages 9.5-10.6 eggs (Haulton 1999, Dobony et al. 2001). Clutch size has also been found to vary among habitat types; Devers and Stauffer (2004) reported mean first clutches on mixed-mesophytic sites in the Appalachians were slightly larger than on oakhickory sites (10.7 vs. 9.4 eggs/clutch, respectively). Females will re-nest if first nests are depredated early in the incubation period; however, a female that loses her clutch late in the incubation period may not have the body reserves or physiological capacity to produce another clutch (Bump et al. 1947). Second nest attempts typically produce fewer eggs (Bump et al. 1947, Rusch and Keith 1971, Larson 1998). The re-nest rate on mixed-mesophytic sites in the Appalachians was 45\%, compared to 3\% in oak-hickory sites (Devers and Stauffer 2004, Devers

et al. 2007). Re-nesting occurs more frequently in the northern range (>50\%; Bump et al. 1947, Small et al. 1996). Re-nesting females averaged 7.5 eggs in New York (Bump et al. 1947). Nest success rate (percentage of nests that successfully hatch $\geq 1$ egg) was $70 \%$ in West Virginia (Dobony et al. 2001), and first-nest success was 44\% in northern Michigan (Larson et al. 2003). Bump et al. (1947) and Dorney and Kabat (1960) reported chick sex ratios of approximately 50:50 in New York and Wisconsin, respectively. 
Rusch and Keith (1971) reported chick survival of $51 \%$ at 12 weeks post-hatch in Alberta, Canada. In northern Wisconsin, Dorney and Kabat (1960) estimated chick survival from June-August at $77 \%$ and $88 \%$ during years when grouse populations were high and low, respectively. These studies were conducted prior to the widespread use of radio-telemetry, and chick survival estimates were visually determined by comparing brood counts to mean clutch sizes. Estimates of chick survival to 5 weeks post-hatch in Virginia and West Virginia range from 9-30\% (Haulton 1999: 11-13\%; Dobony 2000: <30\%; Smith 2006: 9-13\%). Haulton (1999) hypothesized that high chick mortality and complete brood loss (13 of 34 broods) during the first week post-hatch contribute to lower densities of grouse in Virginia and West Virginia than found in the northern range. Devers (2007) reported chick survival in the Appalachians to be $21 \%$ and $39 \%$ on oak-hickory and mixed-mesophytic sites, respectively, suggesting possible forest type influence on chick survival. 


\section{CHAPTER 3 - EFFECT OF NUTRITIONAL DEFICIENCY ON CONDITION OF FEMALE RUFFED GROUSE}

John W. Edwards

Division of Forestry and Natural Resources

322 Percival Hall

West Virginia University

Morgantown, WV 26506-6125

304/293-3796; Fax 304/293-2441

jedwards@wvu.edu

RH: Proctor et al. • Nutritional Deficiency in Female Ruffed Grouse

\section{Effect of Nutritional Deficiency on Condition of Female Ruffed Grouse}

Aaron B. Proctor, Division of Forestry and Natural Resources, West Virginia

University, Morgantown, WV 26506-6125, USA

John W. Edwards, Division of Forestry and Natural Resources, West Virginia

University, Morgantown, WV 26506-6125, USA

Joseph S. Moritz III, Department of Animal Sciences, West Virginia University, Morgantown, WV 26506-6108, USA

Dave E. Steffen, Virginia Department of Game and Inland Fisheries, 6701 Parkway

Drive, Roanoke, VA 24018, USA

George E. Seidel, Department of Statistics, West Virginia University,

Morgantown, WV 26506-6108, USA

ABSTRACT Previous research has reported differences in the nutritional ecology of ruffed grouse (Bonasa umbellus) in their northern and southern ranges, where northern grouse are found in higher densities and maintain less carcass fat (lipid) compared to southern grouse throughout the Appalachians. Differences in the nutritional ecology of Appalachian ruffed grouse have been documented in previous research, but direct effects on body condition leading to the reproductive cycle are unknown. We conducted a 2-year experiment on captive Appalachian ruffed grouse 
(B. u. monticola) to assess the effects of 4 treatment rations varying in dietary energy and crude protein on female body condition throughout the pre-breeding and reproduction periods using total body electrical conductivity (TOBEC) technology. Females on low protein rations maintained higher carcass fat levels than females on high protein treatments, although high protein treatments led to less fat loss during reproduction. High-energy rations produced females with higher fat levels prior to reproduction; however, adult females on high-energy treatments lost more fat during reproduction than low-energy treatments. We posit that the presence of lowprotein, high-energy feed items in diets of Appalachian ruffed grouse potentially lead to higher percent body fat, whereas high-protein diets support leaner grouse. Our findings support the hypothesis that northern ruffed grouse maintain relatively leaner body condition than Appalachian grouse due to year-round availability of protein-rich aspen buds and catkins. Appalachian ruffed grouse may maintain higher fat levels due to lowered dietary crude protein. KEY WORDS Appalachians, Bonasa umbellus, fat condition, nutrition, ruffed grouse, TOBEC, total body electrical conductivity.

The Journal of Wildlife Management 00(0):000-000, 201X Historically, ruffed grouse (Bonasa umbellus) densities are lower in the central and southern Appalachians (hereafter Appalachians) than in the northern portion of the range (hereafter northern range) (Servello and Kirkpatrick 1989a). In the northern range, ruffed grouse densities are reported to range from 7-22 per 100 ha in the Adirondacks of New York (Bump et al. 1947:559) to 41-83 per 100 ha in prime habitat in Minnesota (Gullion 1977). Although stable, ruffed grouse populations in the northern range experience natural fluctuations over an approximate 10-year cycle (Rusch 1989). In the Appalachians, Weber and Barick (1963) reported densities of 7-10 grouse per 100 ha in western North Carolina. Densities of drumming 
male grouse range from $0.25-4.5$ per 100 ha in the Appalachians, which is much lower than the 5.5-22.8 per 100 ha reported in the northern range (Dessecker 2001). Recent evidence suggests that ruffed grouse densities in the Appalachians have declined substantially. USGS Breeding Bird Survey data from 1966-2005 indicates a 5\% annual decline in ruffed grouse populations in the Appalachian region (Sauer et al. 2006). Loss of early successional habitat, due in part to negative public attitude towards even-aged silvicultural management, has been suggested as a factor in these declines (Dessecker and McAuley 2001). Research from the Appalachian Cooperative Grouse Research Project cited low chick survival to 5-weeks and site-specific female body condition differences as possible factors contributing to declining densities in the southern range (Devers 2005, Long 2007).

In the northern range, ruffed grouse are primarily associated with forest types containing aspen (Populus spp.; see Chapter 1 Fig. 1.1) and consume a preponderance of aspen buds and catkins that are nutrient rich and abundant year-round (Bump et al. 1947, Svoboda and Gullion 1972, Gullion 1977, Servello and Kirkpatrick 1987, Barber et al. 1989, Hewitt and Kirkpatrick 1996). Diets of ruffed grouse are more diverse in the Appalachians, where aspen is sparse to absent, and other high-quality forage may be scarce during poor mast years (Servello and Kirkpatrick 1988, Long 2007). When available, hard and soft mast are primary foods of grouse in fall and winter throughout the Appalachians; herbaceous leaves make up the bulk of the diet in spring (Norman and Kirkpatrick 1984, Long 2007). In the Appalachians, Long (2007) reported oak (Quercus spp.) and beech (Fagus spp.) mast comprised 26\% of ruffed grouse crop contents in spring (March and April), although it was found in only $17 \%$ of crops, suggesting that mast is highly selected when available. When hard mast is not available in fall and winter, grouse in the Appalachians consume evergreen leaves that are high in phenolic compounds (Appendix A), 
which compromise nutrient absorption (Hewitt and Kirkpatrick 1997b). Long (2007) reported various species of evergreen leaves in $36 \%$ of ruffed grouse crops collected throughout the Appalachians in April, accounting for $12 \%$ of crop contents; the presence of evergreen leaves was inversely related to hard mast consumption. Such poor-quality diets containing large portions of evergreens such as mountain laurel (Kalmia latifolia) may lead to seasonal nutritional deficiency in Appalachian ruffed grouse (Servello and Kirkpatrick 1987, Hewitt and Kirkpatrick 1997b, Long 2007). Poor nutrition may negatively affect body condition of breeding females and thus influence reproductive success in Appalachian ruffed grouse.

Past studies have examined body condition as a possible factor affecting reproductive success in female galliforms (Breitenbach et al. 1963, Beckerton and Middleton 1983, Giuliano et al. 1996). Carcass fat (lipid) differs in ruffed grouse between the northern range and the Appalachians. Thomas et al. (1975) reported that ruffed grouse in Ontario, Canada maintain low carcass fat levels (5.9-9.3\%) year-round and hypothesized that grouse must feed frequently to maintain basal metabolic energy requirements. Ruffed grouse collected in Michigan, Wisconsin and Minnesota during April had lower carcass fat levels than those collected in the Appalachians during the same period $(6.0 \pm 0.4 \%$ [mean \pm SE] vs. $10.8 \pm 0.4 \%$; Long 2007). It has been hypothesized that ruffed grouse in the northern range can more easily meet their daily nutritional requirements because of the year-round availability of aspen catkins and buds, and therefore maintaining higher fat reserves provides no selective benefit (Svoboda and Gullion 1972, Gullion 1977, Servello and Kirkpatrick 1987, Long 2007). Ruffed grouse in the Appalachians are dependent on food sources of varying quality and availability (i.e., mast) and therefore will attain relatively higher carcass fat levels (i.e., stored energy) when resources are available. Long (2007) reported that when hard mast was present in crops of pre-laying female ruffed grouse 
collected in the Appalachians, percent body fat averaged $20.0 \%$ compared to $11.7 \%$ in those with crops devoid of hard mast.

Long (2007) hypothesized that poor pre-breeding condition in Appalachian ruffed grouse may delay incubation, reduce clutch size and chick survival. Determining the relation between female condition and reproductive success of ruffed grouse in the wild represents a challenging, if not daunting task. In an experimental study of captive ruffed grouse in Ontario, Canada, Beckerton and Middleton (1982) reported increases in rate and duration of egg laying, first egg mass, mean egg mass, clutch size, clutch mass, chick mass at hatch, and chick survival to 9 weeks with increased protein content in test rations fed to females. Although their study represents the only experimentally controlled investigation of nutrition and productivity in ruffed grouse, it did not examine the relation of nutrition to body condition or body condition to productivity.

To test the hypothesis that female condition is related to nutrition, we maintained captive female ruffed grouse on rations differing in dietary energy and crude protein to determine experimentally the effect of nutritional deficiency on pre-laying body condition. Our objective was to assess the effects of dietary energy and crude protein on pre-laying condition of female ruffed grouse. We predicted that female ruffed grouse fed a ration higher in dietary energy and protein would maintain higher carcass fat levels relative to those on deficient rations.

\section{STUDY AREA}

We conducted our research on a captive population of ruffed grouse housed at the West Virginia University Animal Research Farm in Morgantown, West Virginia, USA. The colony was started in 1990 from 12 fertile eggs from a wild nest near Buckhannon, West Virginia (subspecies Bonasa umbellus monticola) and acquired through the West Virginia Division of Natural 
Resources. In 1991, 8 additional adult grouse from West Virginia were added to the colony. From 1992 to 2001, grouse from Pennsylvania ( $n=9$; subspecies B. u. monticola), Minnesota ( $n$ = 2; subspecies B. u. umbellus), and Wisconsin ( $n=10$; subspecies B. u. umbellus) were acquired to increase genetic diversity and limit genetic crossing. At the time our study was initiated in December 2003, the colony contained 190 adult ruffed grouse. We housed birds in individual $60 \times 60 \times 60$-cm wire cages in a curtain-sided, poultry-style building. We maintained natural lighting and ambient environmental conditions except in winter when forced-air heaters maintained temperatures above $10 \mathrm{C}$. During non-experimental periods, grouse were fed a commercial game bird ration (Sporting Bird Flight Developer, Southern States Cooperative, Winchester, Kentucky, USA), with grit and water provided ad libitum.

\section{METHODS}

\section{Experimental Feeding Trials}

We conducted experimental feeding trials from December 2003 - summer 2004 (hereafter called 2004), and replicated these trials in December 2004 - summer 2005 (hereafter called 2005). We randomly assigned 32 juvenile and 32 adult female grouse to 1 of 4 treatments ( 8 juveniles and 8 adults per treatment, $n=64$ total per year). Females available from 2004 did not receive the same treatment in 2005. Adult females were $\geq 1$ and $\leq 4$ years of age; juvenile females were $<1$ year of age. In 2004, mean ages (years) per treatment were 1.53 (control), 1.60 (HE-LP), 1.54 (LE-HP), and 1.53 years (LE-MP). In 2005, mean ages were 1.62 (control), 1.81 (HE-LP), 1.67 (LE-HP), and 2.00 years (LE-MP). We omitted females that failed to lay eggs in 2004 from the candidate pool for 2005. We arranged female cages in stacked rows of 2 adults and 2 juveniles with males separating each group of 4 females. We placed males between groups of females because their presence may facilitate female breeding condition (R. L. Cochrane, West Virginia 
University, personal communication). We arranged cages in 4 rows, stacked 2 high and 12 across (i.e., 24 cages per row; Appendix B). Each row contained an equal number of adult and juvenile females receiving each treatment ration. We used an indoor/outdoor digital thermometer (Model 1441, Taylor ${ }^{\mathrm{TM}}$ Precision Products, Oak Brook, Illinois, USA) to record daily ambient and outside minimum and maximum air temperatures during experimental trials.

In the absence of ration formulation guidelines for ruffed grouse, we used National Research Council guidelines for Japanese quail (Coturnix japonica) as a standard (National Research Council 1994). We formulated rations using Brill ${ }^{\mathrm{TM}}$ Feed Formulation software version 1.03.017-S (Brill ${ }^{\mathrm{TM}}$ Feed Management Systems, Brooklyn Center, Minnesota, USA). We fed females an "over-winter" ration from 1 December - 31 January to acclimate them to a ration lower in dietary energy and protein than the commercial game bird ration (Table 3.1). Our purpose was to maintain all females on a mid-range ration prior to introduction of experimental rations and to acclimate them to higher levels of bulk fiber (F. A. Servello, University of Maine, personal communication).

The reduction in dietary energy (primarily corn) and crude protein (soybean) in our low energy and low protein treatments required the use of a "filler" to replace ingredients removed from the ration. Sibbald $(1980,1981)$ reported that the inclusion of inert filler material such as sand and cellulose into adult cockerel (Gallus gallus) rations did not increase endogenous nutrient losses in the form of sloughed epithelial cells, microbial activity, and digestive secretions. We used soybean hulls and wheat bran (both fibrous, relatively nutrient deficient, and high in cellulose) as filler ingredients in our treatment rations. Females fed low-energy and low-protein rations consumed and subsisted on these formulations, indicating that our lowquality rations were palatable and digestible. 
Our intent was to establish 4 treatment rations on a $2 \times 2$ model based on low and high levels for energy and protein. We fed treatment rations starting 1 February on a time-lag (Giuliano et al. 1996) based on ad libitum consumption of the high energy-high protein control treatment $(2.9 \mathrm{kcal} / \mathrm{g}$ energy, $24 \%$ crude protein; Japanese quail guidelines) group with the exception that feed intake was measured and adjusted twice weekly. Daily average consumption by the control group determined the ration amount given to the 3 fixed-treatment groups the following day. For example, on the first day of the week, we recorded feed intake of the control group $(n=16)$ to determine an average daily intake. On day 2 , we provided this amount of treatment ration to each fixed group. Therefore, we adjusted the quantity of feed offered to fixed groups twice weekly on a 1-day time lag according to average daily consumption of control females. This approach accounted for changes in consumption due to environmental conditions or physiological changes in control females.

Initially, our low energy-low protein, (LE-LP) ration contained one-third the dietary energy and protein of our control ration. We formulated the LE-LP ration to contain $1.0 \mathrm{kcal} / \mathrm{g}$ of dietary energy and $8 \%$ crude protein. Although we desired a treatment (ration) effect on fat condition, our initial formulations failed to support basal metabolic needs, resulting in rapid emaciation and death of 5 females in fixed-treatment groups in February 2004. Consequently, we reformulated experimental rations offered to fixed groups to increase dietary energy from 1.0 to $1.9 \mathrm{kcal} / \mathrm{g}$ and crude protein from 8 to $16 \%$. Following reformulation, we monitored females for 3 weeks and determined that fixed groups required $150 \%$ of the control treatment group's average daily intake to avoid rapid loss of body mass; we observed no further deaths due to nutritional deficiency. Though modifications to rations were made during the 2004 experimental trial, females received these reformulated rations $\geq 7$ weeks prior to onset of egg laying, which 
should have provided females adequate time for physiological acclimation. In 2005, we reformulated the 2004 over-winter ration $(1.9 \mathrm{kcal} / \mathrm{g}$ and $16 \%$ crude protein) to contain $2.4 \mathrm{kcal} / \mathrm{g}$ and $20 \%$ crude protein (mean of low/high energy and low/high protein treatments) based on the aforementioned changes made in treatment (ration) formulations.

Due to the increase in quantity $(50 \%)$ of ration fed to fixed groups, we adjusted treatment designations to reflect increases in dietary energy and crude protein. Our resulting treatment designations based on metabolizable energy and crude protein were: (1) our original control diet fed ad-libitum (control), (2) high energy-low protein (HE-LP), (3) low energy-high protein (LEHP), and (4) low energy-medium protein (LE-MP) (Table 3.1). Thus, we defined 2 levels of dietary energy (low: $2.58-2.63 \mathrm{kcal} / \mathrm{g}$; high: $3.39 \mathrm{kcal} / \mathrm{g}$ ) and 3 levels of dietary protein (low: 1922\%; medium: 26\%; high: $29 \%$ crude protein; Table 3.1). It is important to emphasize that it was our treatment ration designations that changed and not our ration formulations. For metabolizable energy determination between age classes and among treatment rations, we fed fixed-treatment groups their ration on a $100 \%$ basis of the control. Thereafter, all treatment designations related to body condition in this chapter follow our adjusted treatment designations and recognize 2 levels of energy and 3 levels of dietary protein (Table 3.1).

\section{Ration Analysis}

To determine apparent nitrogen-corrected metabolizable energy $\left(\mathrm{AME}_{\mathrm{N}}\right)$, we randomly chose 5 juvenile and 5 adult females that were not used in our 2005 experiment. We determined $\mathrm{AME}_{\mathrm{N}}$ of each ration via 5 feeding trials (over-winter ration and 4 treatment rations), using an adult and juvenile female for each ration per trial. Thus, one juvenile and one adult received a different ration in each of 5 trials until all 10 subjects were fed all 5 rations. Prior to each trial, we fed females commercial game bird ration ad libitum for $\geq 5$ days. To begin a trial, we removed grit 
and fasted subjects for $48 \mathrm{~h}$ to induce hunger and void the gastrointestinal tract of previously ingested feed and excreta. We then placed a clean excreta collection tray under the cage and provided subjects $100 \mathrm{~g}$ of trial ration. After $24 \mathrm{~h}$, we removed and weighed the remaining feed to determine consumption. We immediately fasted subjects again for $48 \mathrm{~h}$ to allow for passage of feed and excreta, after which we removed excreta trays and excreta was collected and placed in pre-weighed plastic sample cups and frozen.

Dry matter and percent nitrogen of rations and excreta were determined in duplicate by the West Virginia University Rumen Fermentation Profiling Laboratory as follows: (1) Ration and excreta samples were lyophilized to constant mass; (2) Dry matter of ration samples was determined using the Association of Official Analytical Chemists (AOAC) protocol 967.03 (AOAC 1990); (3) Percent nitrogen of ration and excreta samples was determined by the Kjeldahl procedure (AOAC protocol 976.05); (4) Gross energy of rations and excreta samples was determined in duplicate using a Parr ${ }^{\mathrm{TM}}$ Model 1266 isoperibol oxygen bomb calorimeter with a Parr Model 1563 water handling system (Parr Instrument Company, Moline, Illinois, USA); (5) We determined retained nitrogen and corrected for eventual uric acid formation and oxidation following Hill and Anderson (1958); and (6) We calculated $\mathrm{AME}_{\mathrm{N}}(\mathrm{kcal} / \mathrm{g})$ on a dry matter basis as follows:

$$
\begin{aligned}
& \mathrm{AME}_{\mathrm{N}}=((\mathrm{F} \times \text { feed } \mathrm{GE})-(\mathrm{E} \times \text { excreta } \mathrm{GE})-(\mathrm{N} \times 8.22 \mathrm{kcal} / \mathrm{g})) / \mathrm{F} \\
& \mathrm{F}=\text { grams of feed consumed } \\
& \mathrm{GE}=\text { gross energy }(\mathrm{kcal} / \mathrm{g}) \\
& \mathrm{E}=\text { grams of excreta } \\
& \mathrm{N}=\text { grams of nitrogen retention }
\end{aligned}
$$




\section{Condition Sampling}

To quantitatively assess body condition, we recorded total body electrical conductivity (TOBEC) and body mass of females bi-monthly from 1 December until the onset of egg laying. Because ruffed grouse lay supernumary clutches in captivity (personal observation of senior author; R. L. Cochrane, West Virginia University, personal communication), we established a cut-off point of $>7$ days between successive eggs to terminate the clutch. We observed grouse laying an egg a day as well as grouse that took $>7$ days between successive eggs. To assess conditional changes during egg laying, we sampled females $\leq 3$ days following clutch termination and again 14 days later.

We fashioned a TOBEC scanning restraint by cutting a $53 \times 35-\mathrm{cm}$ piece of soft, pliable, opaque plastic sheeting that would extend from the tail to $>2.5 \mathrm{~cm}$ beyond the head of an adult grouse. We used 2 sets of self-adhering Velcro ${ }^{\mathrm{TM}}$ strips to close the restraint. We tested the dielectric properties of the empty restraint within the TOBEC scanning chamber and found it neutral, indicating it would not influence sampling results. For sampling, we first tared the weight of the empty restraint on an electronic balance. We then positioned the grouse dorsally onto the open restraint and held its wings folded to the body while we snugly "rolled up" the restraint and secured the Velcro strips, making sure that its legs were extended posteriorly and not positioned ventrally; grouse appeared calm once in the restraint. It was important to secure grouse within the restraint to restrict movement and insure that they remained motionless during the TOBEC scanning process (EM-SCAN Inc. 1993).

We weighed each grouse to the nearest $0.1 \mathrm{~g}$ on an electronic balance prior to determining a TOBEC value using an EM-SCANTM Model SA-3000 small animal body composition analyzer with a Model 3114 (114 mm) detection chamber (EM-SCAN Inc., 
Springfield, Illinois, USA). We recorded 5 scans to obtain a mean TOBEC value for each grouse (EM-SCAN Inc. 1993). Total sampling time (placement in restraint, mass determination, and 5 TOBEC scans) averaged 8-10 minutes. EM-SCAN Inc. (1993) recommends that the coefficient of variation of all measurements for individual subjects not exceed $3 \%$. In preliminary trials, we found that a $3 \%$ coefficient of variation approximated a 20-unit range among 5 scans. Therefore, we recorded 5 scans initially; if the range of these scans exceeded 20 units, outliers were discarded and additional scans were taken until the $3 \%$ coefficient of variation requirement was satisfied.

Measuring total body electrical conductivity provides a non-invasive method for analyzing lean mass in animals without having to sacrifice subjects and perform chemical analysis (Walsberg 1988, Castro et al. 1990). Total body electrical conductivity technology uses a shielded solenoid coil that measures the electromagnetic inductance of the coil when an animal is placed within, thus producing quantifiable electromagnetic impedance (Walsberg 1988). Because lipids possess only $4-5 \%$ of the electrical conductivity of non-lipid tissues such as muscle, fluid, and bone (Pethig 1979), TOBEC allows researchers to accurately assess lean mass or fat mass composition of animals.

\section{Chemical Analysis of Sacrifices}

For TOBEC readings to accurately predict condition required lab-determined body composition of female grouse sampled via TOBEC. We determined TOBEC values and body mass of 7 juvenile females in December 2003 and 9 adult females in October 2005. Following these measures, we immediately sacrificed grouse via carbon dioxide asphyxiation (West Virginia University Animal Care and Use Committee protocol 03-0913) and placed carcasses in air-tight bags and froze them. Sacrificed grouse were frozen for preservation until the next processing 
stage ( $<3$ months) and because partially frozen grouse are easier to process $(\mathrm{C}$. R. Long, West Virginia University, personal communication). Sacrificed grouse were all maintained on a commercial game bird ration with grit and water ad libitum to assure consistent gastrointestinal fill.

Frozen carcasses were allowed to partially thaw for $<2 \mathrm{~h}$ before processing. We plucked feathers, removed the head at the base of the cranium, and removed legs at the base of the tibiotarsus-tarsometatarsus junction. We removed the gastrointestinal and reproductive tracts from the body cavity, stripped visible fat adhering to them and placed it back within the body cavity. We then discarded gastrointestinal and reproduction tracts. We cut whole carcasses into $1-3-\mathrm{cm}$ pieces and refroze them. We partially thawed frozen pieces and ground them in a Biro ${ }^{\mathrm{TM}}$ meat grinder (Model 812, Biro Manufacturing Company, Marblehead, Ohio, USA), placing ground contents in $21.6 \times 11.4 \times 6.4-\mathrm{cm}$ aluminum baking pans. After lyophilizing for $96 \mathrm{~h}$ to constant mass, we reweighed the dried contents to determine initial percent moisture. We homogenized dried contents in a commercial blender (Model CB10, Waring ${ }^{\mathrm{TM}}$, Torringtown, Connecticut, USA), and placed 3 10-g subsamples in airtight plastic bags, and froze.

Chemical analyses of sacrifice homogenates were performed in duplicate by the West Virginia University Rumen Fermentation Profiling Laboratory as follows: (1) Homogenates were analyzed to determine residual moisture (AOAC protocol 967.03), lipid mass (protocol 920.39), crude protein (protocol 976.05), and percent ash (protocol 942.05; AOAC 1990); (2) Residual moisture was determined on 2.0-g homogenate subsamples oven dried at $110 \mathrm{C}$ for 12 h; (3) Lipids were extracted from 1.5-2.0-g subsamples using petroleum ether in a Soxhlet apparatus for 18-24 h; (4) Percent protein (nitrogen $\times 6.25$ ) was calculated on $20.75-\mathrm{g}$ subsamples using the Kjeldahl procedure; (5) Percent ash was determined using 2 3.0-g 
subsamples combusted at $550 \mathrm{C}$ for $12 \mathrm{~h}$ in a muffle furnace; and (6) Residual moisture and initial percent moisture were summed to determine total percent moisture of carcass samples.

\section{Calibration of TOBEC Unit}

Our calibration procedures entailed regressing recorded TOBEC and body mass values against lab-derived fat or lean mass measures from sacrificed grouse to develop predictive equations. In a study of 11 species of small mammals and birds, Walsberg (1988) found that a second-order polynomial model provided the best fit for a multi-species predictive equation. However, Castro et al. (1990) reported a first-order polynomial model provided the best fit among 8 species. Scott et al. (2001) suggest that first-order models best fit intraspecific investigations involving subjects that span a narrow or fixed range of fat variation; Whereas, second-order models best fit interspecific studies that span a greater range of fat and body mass variation. Based on these recommendations, we expected a first-order polynomial regression model to most accurately predict percent fat and lean mass from chemical analysis of our sacrifices. We applied direct models instead of 2-stage models for predicting fat from TOBEC value and body mass due to increased relative error associated with the latter approach (Morton et al. 1991, Snyder et al. 2005). We used predictive models containing TOBEC value and body mass to estimate fat and lean mass levels in experimentally fed female grouse.

\section{Condition Determination}

We used 4 metrics to assess female ruffed grouse body condition through time: (1) pre-laying fat: change in percent fat from 1 December to onset of laying; (2) laying fat: average of 3 consecutive TOBEC and body mass measures (early March through onset of laying) to quantify mean fat levels at onset of laying; (3) reproduction fat: change in percent fat from laying fat determination (metric 2) through the last TOBEC and body mass measure 14 days after clutch 
determination (i.e., change in condition as a result of reproduction); and (4) post-laying fat:

estimated fat determined by last TOBEC and body mass measure 14 days after clutch determination. We used pre-laying body mass (the last recorded body mass measure prior to laying) as a predictor variable in our ANOVA analyses, but we did not consider it a condition variable because body mass alone does not quantify a value for fat mass. Initially we attempted to use lean mass as a condition indice; however, very low variation led us to eliminate it from analysis. Larger grouse possess more lean mass due to larger skeletal frames, especially between age classes. Percent lean mass is likely a fixed physiological parameter in ruffed grouse, whereas percent fat can fluctuate drastically among individuals and season-to-season in the same bird, regardless of skeletal size. Long (2007) reported little variation in lean mass despite wide variation in fat mass for wild ruffed grouse from the northern range and Appalachians.

\section{Statistical Analysis}

All statistical analyses were performed using SAS $^{\mathrm{TM}}$ version 9 (SAS Institute Inc., 2002-2004).

We arcsine transformed all percent condition variables (change in pre-laying fat, laying fat, change in fat during reproduction, and post-laying fat; Table 3.2) for analyses, but report untransformed means and standard errors. We conducted an analysis of variance test in a completely random design with factorial arrangement of treatment ration and year parameters (ANOVA; PROC GLM) to determine differences in $\mathrm{AME}_{\mathrm{N}}$ among treatment rations, trials, and between age classes while testing all two-way interactions. We used Tukey's Honestly Significant Difference test and linear contrasts to determine age class and trial interactions in our $\mathrm{AME}_{\mathrm{N}}$ analyses. To determine if environmental conditions differed between years, we examined minimum and maximum ambient and outside temperatures using analysis of covariance (ANCOVA; PROC GLM). We used ANCOVA with linear contrasts to determine whether mean 
daily intake within the control treatment group differed between years, using experiment week (e.g., 1, 2, 3) as a covariate and year as a blocking factor.

Because TOBEC and body mass were moderately correlated $\left(r_{s}=0.69, P=0.003\right)$, we conducted diagnostic tests to determine level of collinearity. We found a variance of inflation factor (VIF option, PROC REG) of 2.42 for both TOBEC value and body mass, indicating the use of both parameters together would not result in model overfitting (Der and Everitt 2002). In addition, we calculated collinearity indices (COLLIN option, PROC REG) of 15.84 and 29.07 for TOBEC value and body mass, which also indicated that including both parameters would not produce erroneous values for percent fat.

We used linear regression analysis (PROC REG) to develop direct models to estimate percent fat. We tested the following candidate models to predict percent fat $(\mathrm{PF})$ :

Model 1: $\mathrm{PF}=$ Body mass

Model 2: $\mathrm{PF}=$ TOBEC value

Model 3: $\mathrm{PF}=$ Body mass + TOBEC value

To assess the effects of nutritional deficiency on body condition, we used an analysis of variance test in a completely random design with factorial arrangement of treatment ration and year parameters (ANOVA; PROC GLM) to determine effects of treatment and year on each of our 4 fat condition variables (Table 3.2). We treated year as a blocking factor in the analysis of each condition variable. We used an alpha level of 0.05 to determine significance in all analyses. We tested differences of means using Tukey's Honestly Significantly Difference test $\left(\mathrm{HSD}_{0.05}\right)$. We investigated all plausible two-way interactions using linear contrasts. 


\section{RESULTS}

Environmental temperatures.- Mean indoor minimum temperature at the grouse facility was $12.7 \pm 0.33 \mathrm{C}$ in 2004 and $12.2 \pm 0.28 \mathrm{C}$ in 2005 ; whereas mean maximum temperature was 18.9 $\pm 0.44 \mathrm{C}$ in 2004 and $17.9 \pm 0.42 \mathrm{C}$ in 2005 . Mean minimum temperature outside of the facility was $4.2 \pm 0.68 \mathrm{C}$ in 2004 and $3.5 \pm 0.63$ in 2005 ; mean maximum outside temperature was 19.0 $\pm 0.82 \mathrm{C}$ in 2004 and $18.5 \pm 0.79 \mathrm{C}$ in 2005 . Mean minimum and maximum outside temperature at the ruffed grouse facility were similar between years $\left(F_{1,422}=1.17, P=0.281 ; F_{1,422}=0.18, P\right.$ $=0.673$; respectively); however, mean minimum and maximum indoor temperatures were higher in 2004 than $2005\left(F_{1,415}=4.08, P=0.044 ; F_{1,415}=5.05, P=0.025\right.$, respectively $)$.

Feed intake.- Mean daily intake within the control group was $20.93 \pm 0.19 \mathrm{~g}(15.20-27.30)$ and was similar between years and age classes $\left(F_{1,168}=1.77, P=0.186 ; F_{1,168}=0.01, P=0.916\right.$, respectively); however, intake varied week to week as control females increased consumption as they approached reproduction $\left(F_{1,168}=25.90, P \leq 0.001\right.$; Figure 3.1$)$. We found no year $\times$ age interaction $\left(F_{1,168}=0.08, P=0.777\right)$. Daily intake among fixed-treatment groups $(\mathrm{HE}-\mathrm{LP}, \mathrm{LE}-$ HP, LE-MP) also increased concomitantly as the amount of ration offered remained at $150 \%$ of the control group's mean intake (Figure 3.1).

Metabolizable energy. — Juveniles processed more metabolizable energy from rations than adults $\left(F_{1,27}=8.38, P=0.014 ; 2.27 \pm 0.11 \mathrm{kcal} / \mathrm{g}\right.$ vs. $\left.1.95 \pm 0.12\right)$; however, linear contrasts revealed that this occurred in only one trial (trial $1 ; F_{1,11}=19.75, P=0.001$ ) and one treatment (LE-MP; $F_{1,11}=5.71, P=0.036$ ), and therefore we felt justified in combining age classes for subsequent analysis. We initially compared metabolizable energy among original treatment rations on a gram-to-gram basis (Table 3.1) and found a significant treatment effect regarding $\operatorname{AME}_{\mathrm{N}}\left(F_{3,27}=14.91, P \leq 0.001\right)$. We then examined our adjusted treatment $\mathrm{AME}_{\mathrm{N}}$ using 
Tukey's Honestly Significant Difference test and found that our HE-LP ration had higher $\mathrm{AME}_{\mathrm{N}}$ than the other 3 treatments $\left(\mathrm{HSD}_{0.05}=0.631\right.$; Table 3.1).

Condition modeling. - Although body mass alone (Model 1) effectively predicted percent fat $\left(F_{1,14}=25.65, P \leq 0.001 ;\right.$ adjusted $\left.R^{2}=0.62\right)$, the addition of TOBEC $\left(\right.$ partial $R^{2}=0.18$;

Appendix C) increased the explanatory power (Model 3; adjusted $R^{2}=0.81$ ) and therefore was selected to predict fat condition in female grouse as follows:

Model 3: $\mathrm{PF}=-27.621+(0.155 \times$ Body mass $)-(0.082 \times$ TOBEC value $)$ Validation of this model on an independent sample of female grouse (5 juveniles and 5 adults) explained $83 \%$ of variation in percent body fat (adjusted $R^{2}=0.83, P \leq 0.001$; Appendix D), and was used to assess female fat condition through time.

Pre-laying fat.- In 2004 and 2005, females on control and HE-LP treatments gained fat mass during the pre-laying period; whereas the LE-HP treatment showed no significant gain in fat $\left(F_{3,106}=11.12, P<0.001 ;\right.$ Tukey's $H_{S D} D_{0.05}=2.16$; Tables 3.3 and 3.4 $)$. There was a year $\times$ treatment interaction for the LE-MP treatment group between 2004 and 2005 that was not found in the other 3 treatments (Tables 3.3 and 3.4). The control and HE-LP groups gained fat in 2004, while LE-HP and LE-MP groups showed either no fat gain or fat loss (Table 3.4).

Laying fat.- Females in the control, HE-LP, and LE-MP treatment groups had the highest percent fat at laying $(18.61 \pm 1.67)$ and HE-LP females possessed more fat than our LE-HP $(13.38 \pm 0.87)$ treatment group (Tables 3.5 and 3.6). There was a year effect $\left(F_{1,109}=18.52, P\right.$ $<0.001)$, where laying fat among females was lower in 2004 than in 2005 (13.57 \pm 0.86 [3.8933.92] and $18.24 \pm 0.93$ [8.46-43.46], respectively). The nearly significant interaction between year and treatment $(P=0.053)$ resulted from the LE-MP group differing between 2004 and 2005 
(Table 3.6). Although laying fat was lower in the other three treatment groups in 2004, differences between treatments remained similar between years (Table 3.6).

Reproduction fat. - Change in percent fat during reproduction in females was similar among treatment rations (Tables 3.7 and 3.8). In 2004, females lost less fat during reproduction than in $2005(-2.65 \pm 0.82[n=48]$ and $-5.46 \pm 0.84[n=48]$, respectively; Table 3.8).

Post-laying fat. - Percent post-laying fat of females was similar among treatments (Tables 3.9 and 3.10). We found a year effect where post-laying fat was higher among females in 2005 (Table 3.10). Post-laying fat was positively related to pre-laying fat across treatments and years $\left(r_{\mathrm{s}}=0.659, P \leq 0.001\right)$.

Pre-laying body mass. - Pre-laying body mass was related to treatment ration $\left(F_{3,109}=4.31\right.$, $P=0.007)$, where females in the control treatment had greater body mass than LE-MP females (Tables 3.11 and 3.12). Pre-laying body mass among females was similar between years $\left(F_{1,109}\right.$ $=2.99, P=0.087)$. We found a significant interaction between year and treatment, where females in the LE-MP treatment had substantially lower body mass in 2004 than in 2005 (Tables 3.11 and 3.12). Pre-laying body mass in the remaining three treatment groups was similar between 2004 and 2005 (Table 3.12).

Reproductive failure.- Among treatments, $11 \%$ (6 of 55) of females in 2004 and $16 \%$ (9 of 58) of females in 2005 failed to lay at least one egg. The proportion of non-layers was similar between years $\left(\chi^{2}=0.068, P=0.794\right)$ and among treatment rations $\left(\chi^{2}=6.732, P=0.081\right)$. Among the 15 non-layers (control = 1, HE-LP = 3, LE-HP = 7, LE-MP = 4), 2 females that laid eggs in 2004 failed to lay in 2005. Both were in the LE-HP treatment group in 2005, one had been in the control group in 2004 while the other was in the HE-LP group. The remaining non- 
layers $(n=13)$ either failed to lay in 2004 and were removed from the candidate pool for 2005 or were first-time subjects in 2005 .

\section{DISCUSSION}

Our goal in formulating treatment rations was to: (1) provide female grouse with varying levels of dietary energy and protein to induce multiple planes of fat condition, (2) control for possible confounding factors by providing females a calculated and homogenous ration, and (3) provide energy and protein levels approximating those found in diets of wild grouse. Although replicating exact nutritional parameters of wild grouse is impossible in captive experimentation, our treatment rations provided comparable energy and protein levels that yielded varying planes of fat condition prior to the reproductive cycle. Our design focused on nutrition as the primary determinant in body condition while minimizing environmental factors and physiological stressors such as foraging, local food shortages, thermoregulation, and avoidance of predators.

Body fat is generally considered the most important factor in determining overall yearround body condition in birds (Johnson et al. 1985, Long 2007). Percent body fat values in ruffed grouse reported in the north (5.9-9.2\%; Thomas et al. 1975) are much lower than we found in our treatment females during the pre-laying period (although we had 3 outliers below 5.9\% fat). Long (2007) reported pre-breeding body fat values in female ruffed grouse of 5.68.3\% in the Appalachians and from 6.7-7.9\% in the northern range states of Minnesota, Wisconsin, and Michigan. We found fat condition at onset of laying (laying fat) (15.9\% [3.943.5]) comparable to Long's (2007) findings (9.9\% [1.3-39.7]), although our higher mean may have been attributable to less energy expenditure of captive birds. Therefore, we only used fat condition parameters to reflect female nutritional condition leading up to reproduction, at laying 
onset, and during egg laying. Our focus was to determine the role of dietary protein and energy in fat condition of female grouse.

Previous research presents contrasting conclusions regarding dietary protein consumption. Findings suggest that galliformes eat to satisfy basal energy requirements and protein deficiencies are not believed to lead to increased food consumption (Nestler 1944, Hill and Dansky 1954, Cain et al. 1963, Barrett 1969, National Research Council 1984, Giuliano et al. 1996). Klasing (1998) reported that marginal amino acid (protein) deficiencies could be compensated for in galliformes and anseriformes via increased food intake, which in turn could lead to greater fat deposition and increased body mass due to more ingested energy. More moderate amino acid deficiencies also can be compensated for via food intake, but the proportion of fat deposited relative to skeletal muscle catabolism could result in net body mass loss (Klasing 1998). Early in our 2004 experiment it is likely that our initial treatment rations were highly deficient in energy and protein, resulting in the loss of 5 females due to rapid body fat and lean mass catabolism. Females had the highest body fat when fed high-energy, low-protein ration, indicating females readily deposited body fat when fed a low protein:calorie diet. Overconsumption in females on high-energy, low-protein treatment ration was impossible because the 3 restricted treatments were fed the same amount of ration daily. Kirkpinar and Oguz (1995) found that increased levels of dietary protein in male Japanese quail resulted in lowered body fat when dietary energy was held constant. We found a similar relation with regard to our low, medium, and high protein rations.

Body fat is considered most affected by metabolizable energy in the diet and how much energy a bird uses in its daily activities (i.e, "energy in minus energy out”) (Klasing 1998). Energy deficiency in female galliforms results in delayed egg-laying, ovarian degeneration, and 
reduced egg production (King 1973). Metabolizable energy in treatment rations ranged from $1.72-2.62 \mathrm{kcal} / \mathrm{g}$, and in some cases was lower than dietary energy levels of wild grouse in Virginia (2.30-2.68 kcals/g; Servello and Kirkpatrick 1988). Dietary composition can be viewed as a protein:calorie ratio, where high ratios (protein rich) lead to lower energy intake and lower body fat, and low ratios (energy rich) lead to lower protein intake and more energy for fat deposition (Klasing 1998). Protein:calorie ratios in wild ruffed grouse in the southern range are lower than the northern range, resulting from diets having increasingly lower dietary protein and higher energy from north to south (Servello and Kirkpatrick 1987). Servello and Kirkpatrick (1987) reported that although very low in protein, acorns $(3.55 \mathrm{kcal} / \mathrm{g} ; 7.0-8.0 \%$ protein) are very high in metabolizable energy and Servello and Kirkpatrick (1988) reported that acorns made up $60 \%$ of crop contents of grouse collected in the spring following an above average mast year in Virginia. Long (2007) found grouse had $71 \%$ more fat when acorns contributed to the majority of the diet. Our findings and those of Long (2007) support that (1) diets higher in metabolizable energy will lead to increased body fat, (2) grouse select energy rich food items (i.e., acorns) when available, and (3) the level of dietary protein may function to keep grouse leaner when protein:calorie ratio is high. Assuming protein deficiencies are rare in wild grouse consuming native foods, it is likely grouse will select energy-rich items (e.g., acorns) when available because they represent quick and easily obtained dietary energy to maintain body mass.

Although $13 \%$ of our females failed to lay eggs in both years, we found no relation between protein level and failure to lay. Non-nesting in wild ruffed grouse is uncommon (4\%; Devers 2005) and considered the result of physiological abnormalities (Bump et al. 1947). Our range in dietary protein was higher than found in the diet of wild grouse; however, we were able 
to determine that all rations enabled females to reproduce, indicating that we had no measurable amino acid deficiencies.

\section{ACKNOWLEDGMENTS}

We thank the West Virginia University Division of Forestry and Natural Resources and the Richard King Mellon Foundation for funding. R. Cochrane was generous in allowing us the use of his facility and ruffed grouse and for providing his expertise and insight in maintaining healthy grouse in captivity. Thanks to B. Sparks for data collection and care of the grouse. The West Virginia University Rumen Fermentation Profiling laboratory conducted all proximate analyses. We also thank the Department of Fisheries and Wildlife Sciences at Virginia Tech for use of their TOBEC unit. 


\section{CHAPTER 4 - EFFECTS OF FAT CONDITION ON FECUNDITY IN RUFFED GROUSE}

John W. Edwards

Division of Forestry and Natural Resources

322 Percival Hall

West Virginia University

Morgantown, WV 26506-6125

304/293-3796; Fax 304/293-2441

jedwards@wvu.edu

RH: Proctor et al. • Fat condition and fecundity in ruffed grouse

\section{Effects of Fat Condition on Fecundity in Ruffed Grouse}

AARON B. PROCTOR, Division of Forestry and Natural Resources, West Virginia

University, Morgantown, WV 26506-6125, USA

JOHN W. EDWARDS, Division of Forestry and Natural Resources, West Virginia

University, Morgantown, WV 26506-6125, USA

JOESEPH S. MORITZ III, Department of Animal Sciences, West Virginia University, Morgantown, WV 26506-6108, USA

ROBERT L. COCHRANE, Department of Animal Sciences, West Virginia University, Morgantown, WV 26506-6108, USA

GEORGE E. SEIDEL, Department of Animal Sciences, West Virginia University, Morgantown, WV 26506-6108, USA

ABSTRACT Maternal body fat condition (i.e., percent carcass fat) is often a focal point in determining reproductive success in female galliforms. Previous research has centered around habitat-related nutritional parameters affecting body condition and the influence on reproductive capacity. Past studies have shown that ruffed grouse (Bonasa umbellus) maintain higher mean body fat levels throughout the Appalachians and variation in body condition exceeds that found in northern grouse. In the Appalachians, ruffed grouse with diets devoid of energy-rich hard 
mast have lower body fat condition. It has been hypothesized that females in poorer condition will have lower productivity in the Appalachians (Devers and Stauffer 2004, Devers 2005, Long 2007). We conducted a 2-year study of captive Appalachian ruffed grouse (subspecies Bonasa umbellus monticola) to determine the effect of body fat condition on onset of laying, egg quality, clutch size, and chick mass at hatch. We used 4 experimental treatment rations to stratify females into differing fat condition classes, ranging from $3.9-43.5 \%$ body fat. Although egg composition differed among condition classes, we found no evidence of a relation between fat condition and egg composition. Female grouse were capable of producing comparable eggs, clutches, and chicks across varying planes of body fat condition. Our results suggest that the effect of increased fat reserves in Appalachian ruffed grouse does not directly influence fecundity. We propose that any influence female condition has on fecundity and chick survival is enacted after the nesting effort is complete.

KEY WORDS Appalachian region, Bonasa umbellus, fat condition, ruffed grouse, TOBEC, total body electrical conductivity.

The Journal of Wildlife Management 00(0):000-000, 201X Ruffed grouse (Bonasa umbellus) densities are lower in the central and southern Appalachians (hereafter called the Appalachians) than in the core northern range comprising the Great Lake states into Canada (hereafter called the northern range; Servello and Kirkpatrick 1989a). Although historically lower in the southern range, observational evidence over the past few decades suggest declines in ruffed grouse densities throughout the Appalachians. United States Geological Service's Breeding Bird Survey data from 1966-2005 indicates a 5\% annual decline in ruffed grouse populations in the Appalachian region (Sauer et al. 2006). Potential factors for 
the decline include the loss of early-successional habitat, poor nutritional condition, and low productivity (Devers and Stauffer 2004, Long et al. 2004, Smith et al. 2004, Devers et al. 2007).

Researchers have suggested that differences in nutritional ecology in Appalachian grouse may lead to variation in body fat condition (Norman and Kirkpatrick 1984, Servello and Kirpatrick 1987a, Hewitt 1994, Long 2007). Long (2007) reported that when hard mast was present in crops of female ruffed grouse collected in the Appalachians, body fat averaged 20.0\% compared to $11.7 \%$ in grouse whose crops were devoid of hard mast. Chick survival to 5 weeks post-hatch in the Appalachians was higher where females had moderate (37\% survival) and high (26\% survival) levels of fat compared to females with lower fat levels (13\% survival; Long 2007). Moreover, Devers and Stauffer (2004) found a positive correlation between chick survival and hard mast production the previous fall in the Appalachians, suggesting a possible link between female condition and fecundity, as well as a female's ability to rear chicks posthatch.

Determining the relation between female fat condition and fecundity in wild ruffed grouse would be a challenging, if not daunting task. To examine this possible relation, we maintained captive ruffed grouse on 4 different test rations to experimentally determine the effect of female condition on reproduction. Specifically, our objective was to assess the relation of body condition to clutch initiation date (i.e., onset of laying), egg mass, clutch size, egg quality (i.e., egg protein and egg fat), and chick mass at hatch. We hypothesized that females with higher body fat would produce larger eggs and clutches, have better egg quality, and larger chicks at hatch. We also hypothesized that females in higher fat condition at onset of laying would have higher post-laying percent body fat than females with lower percent body fat at onset. 


\section{STUDY AREA}

We conducted our research on a captive population of ruffed grouse housed at the West Virginia University Animal Research Farm in Morgantown, West Virginia, USA. The colony was started in 1990 from 12 fertile eggs from a wild nest near Buckhannon, West Virginia (subspecies $B . u$. monticola) and acquired through the West Virginia Department of Natural Resources. In 1991, 8 additional adult grouse from West Virginia were added to the colony. From 1992 to 2001, grouse from Pennsylvania $(n=9$; subspecies B. $u$. monticola), Minnesota $(n=2$; subspecies $B$. $u$. umbellus), and Wisconsin ( $n=10$; subspecies $B . u$. umbellus $)$ were acquired to increase genetic diversity and limit genetic crossing. At the time our study was initiated in December 2003, the colony contained 190 adult ruffed grouse. We housed birds in individual $60 \times 60 \times 60$-cm wire cages in a curtain-sided, poultry-style building. We maintained natural lighting and ambient environmental conditions except in winter when forced-air heaters maintained temperatures above $10 \mathrm{C}$. During non-experimental periods, grouse were fed a commercial game bird ration (Sporting Bird Flight Developer, Southern States Cooperative, Winchester, Kentucky, USA), with grit and water provided ad libitum.

\section{METHODS}

We maintained 128 captive female ruffed grouse on experimental rations varying in dietary energy and protein to elicit fat condition responses (West Virginia University Animal Care and Use Committee protocol 03-0913; see Chapter 3, page 39). Body fat condition (percent carcass fat) was assessed via total body electrical conductivity (TOBEC) technology throughout the prelaying period from 1 February through the onset of egg laying. We used body fat to assess female condition in relation to reproductive output (onset of laying, egg production, egg quality, 
and chick mass at hatch). We placed females into classes according to body fat using 5\% increments (Table 4.1).

\section{Egg Sampling}

Females were bred via artificial insemination using semen from colony males. Prior to laying in 2004, we placed a paperboard pigeon nest $(19 \times 5-\mathrm{cm}$ nest cup) and nest pad (Foy's Pigeon Supplies, Beaver Falls, Pennsylvania, USA) in each female's cage. We collected eggs twice daily and replaced them with wooden quail eggs (Murray McMurray Hatchery, Webster City, Iowa, USA); grouse-sized artificial eggs were not available. Our purpose in replacing eggs with wooden surrogates was to reduce the tendency of supernumary clutches often exhibited in captive ruffed grouse (R. L. Cochrane, West Virginia University, personal communication) and to promote determinate-sized clutches (A. L. Middleton, University of Guelph, Ontario, personal communication). Collected grouse eggs were placed in incubators (Petersime ${ }^{\mathrm{TM}}$ models 1 and 4) and hatchers (Petersime model H-145) to rear eggs and aid in hatching (Petersime Incubator Company, Gettysburg, Ohio, USA). Incubation methods were determined via Bump et al. (1947).

Females in 2004 largely ignored the presence of wooden eggs and only one female exhibited any signs of incubating an artificial clutch. Therefore, we ceased replacing collected eggs in 2005, although nests were still provided. To overcome supernumary clutches, we established a cut-off point of $>7$ days between successive eggs to terminate the clutch, and any eggs laid thereafter were excluded from our data analysis. We artificially inseminated females following their first egg to standardize time of insemination and for ease of inserting the insemination tube into the oviduct (R. L. Cochrane, personal communication). Thus, first eggs from each female were infertile and were selected for composition analysis in both years. In 
addition, we randomly selected either the middle or last egg in the clutch from each female in 2004 for analysis, for a total of 2 eggs per female. In 2005, we selected the first (unfertile) and sixth egg (if laid) in the clutch from each female for compositional analysis (see below).

Collected eggs were labeled, weighed to the nearest $0.1 \mathrm{~g}$, placed in standard dozen-sized cardboard chicken egg crates, and refrigerated at $10 \mathrm{C}$. We positioned egg crates at 45 -degree angles and rotated them 90 degrees on their vertical axis daily (45 degrees to 135 degrees) to avoid pre-mature death due to settling. Rotating eggs in this manner and placing them in a cooled state for up to 2-3 weeks ceases development and keeps eggs viable prior to incubation (R. L. Cochrane, personal communication).

In 2004 we kept all of a female's eggs refrigerated until the clutch was complete in an attempt to hatch entire clutches at once. We placed completed clutches into incubators (Models 1 and 4, Petersime) - following $24 \mathrm{~h}$ at room temperature - and hatchers (Model H-145) following procedures of Bump et al. (1947). Because some females laid supernumary clutches some eggs remained refrigerated for over 2 months prior to incubation. We noticed poor hatch success of late-clutch eggs in the 2004 experiment. It has been suggested that sperm remain viable for a maximum of 21 days within the oviduct of female grouse (R. L. Cochrane, personal communication), which could explain the poor hatch success of late-clutch eggs. Previous observations at the grouse facility showed that hatching success drop markedly if the egg was held in a cooled state $>14$ days (R. L. Cochrane, personal communication). In 2005, we collected eggs as in 2004, but equilibrated and set eggs in incubators once weekly, regardless of whether or not a female had finished laying a determined clutch. Thus for 2005, we incubated cohorts of eggs across numerous females instead of entire clutches of individual females at a time, and therefore eggs were held in a refrigerated state $\leq 7$ days prior to incubation. 
We recorded total mass $(0.001 \mathrm{~g})$, length and width $(0.1 \mathrm{~mm})$, and volume $(1 \mathrm{ml})$ of eggs collected for analysis; we weighed egg content $(0.001 \mathrm{~g})$ and wet and dry mass of the shell (0.001 g) separately. Compositional analysis of eggs was conducted by the West Virginia University's Rumen Fermentation Profiling laboratory following AOAC protocol (1990). After homogenizing yolk and albumin portions, we lyophilized eggs to constant mass and subsampled for repeat measurements of percent crude protein, fat, residual moisture, and ash. All tests were performed on a dry matter basis. We found egg content mass (yolk and albumin), egg width, egg length, and egg volume highly correlated with egg mass $\left(r_{\mathrm{s}} \geq 0.66, P \leq 0.001\right)$, thus we did not use them as response parameters. We did not consider egg moisture and shell mass as important indices of nutritional condition and did not include them in our analyses, but they are provided in Appendix E. We used onset of laying (date), egg mass per female (g), clutch size, and chick weight per female (g) metrics in our analyses.

\section{Statistical analysis}

All statistical analyses were performed using SAS $^{\mathrm{TM}}$ version 9 (SAS Institute Inc., 2002-2004). Prior to analyses we tested all variables for normality (NORMAL option, PROC UNIVARIATE, SAS Institute, 2002-2004), and arcsine transformed all independent percent parameters for analyses, but report untransformed means and standard errors. We used analysis of covariance (ANCOVA; PROC GLM) to test if minimum and maximum ambient and outside temperatures differed annually.

Predictive parameters. - For assessing female ruffed grouse condition through time we determined body condition using the average of 3 consecutive TOBEC and body mass measures from early March through onset of laying. We divided this metric into classes for use in oneway analysis of variance as a categorical independent parameter (ANOVA; PROC GLM). 
Determination of female condition in relation to sampling period, ration schedule, and calendar date are found in Appendix F, and a complete list of all variables used in analyses is in Table 4.1. Lastly, we established "post-laying fat" by the final sampling event 2-weeks post-clutch determination. Although not used as a predictor variable, we used Spearman's correlation coefficient (SPEARMAN option, PROC UNIVARIATE) to determine if females in higher prelaying fat condition remained in better condition after reproduction.

To test for collinearity among independent variables we used Spearman's Correlation Coefficient. We used one-way ANOVA to test for differences in condition classes with regards to egg composition and production parameters. We initially used age class (juvenile, adult) and year as fixed parameters in all tests. Although there were significant age class effects with regards to some parameters tested, there were no discernible trends regarding whether adult metrics exceeded juveniles. Therefore, we decided to combine age classes for final analyses. We investigated all plausible two-way interactions using linear contrasting to test each significant interaction.

For egg composition, we tested body condition separately for relations with egg mass (g), egg protein (\%), and egg fat (\%). Parameters of interest for egg production included mean egg mass (g) per female (whereas individual egg masses where analyzed for composition analysis), onset of laying (date), clutch size, and mean chick hatch mass (g) per female. We tested all production parameters with each independent parameter separately as with egg composition. Interclutch composition analysis across first, middle, and last clutch eggs in 2004 was not possible due to the manner in which we sampled; females laid vastly different sized clutches, therefore comparisons between fixed egg positions within clutches were not possible due to sample size. However, we were able to test first eggs in 2004 for egg composition differences 
using the 3 independent parameters described above. First eggs between years where compared for differences in composition with one-way ANOVA. For 2005, we tested egg composition from first to sixth eggs nested by female (intraclutch) with one-way ANOVA, as well as interclutch differences across first and sixth eggs with regards to independent test parameters. An alpha level of 0.05 was used to determine significance in all analyses.

\section{RESULTS}

In 2004, 55 females laid eggs from 7 April-18 June; 6 (9.8\%) females failed to lay. In 2005, 58 females laid eggs from 10 April-25 June; 9 (13.4\%) females failed to lay. Mean indoor minimum temperature at the grouse facility was $12.7 \pm 0.33 \mathrm{C}$ in 2004 and $12.2 \pm 0.28 \mathrm{C}$ in 2005; mean maximum indoor temperature was $18.9 \pm 0.44 \mathrm{C}$ in 2004 and $17.9 \pm 0.42 \mathrm{C}$ in 2005 . Mean minimum temperature outside of the facility was $4.2 \pm 0.68 \mathrm{C}$ in 2004 and $3.5 \pm 0.63 \mathrm{C}$ in 2005; mean maximum outside temperature was $19.0 \pm 0.82 \mathrm{C}$ in 2004 and $18.5 \pm 0.79$ in 2005 . Mean minimum and maximum outside temperatures at the ruffed grouse facility were similar between years $\left(F_{1,422}=1.17, P=0.281 ; F_{1,422}=0.18, P=0.673\right.$; respectively $)$; however, mean minimum and maximum indoor temperatures were higher in 2004 than $2005\left(F_{1,415}=4.08, P=\right.$ $0.441 ; F_{1,415}=5.05, P=0.025$, respectively)

\section{Egg composition}

During 2004 and 2005, 103 females provided 154 eggs for analysis. We discarded three, small $(<10.0 \mathrm{~g})$ eggs from 2005 as outliers, because this threshold has been observed to be critical for egg hatchability at the grouse facility (R. L. Cochrane, personal communication).

Intraclutch comparison.- For change in egg composition within clutches (nested model), we found no differences in egg composition among first, middle, or last eggs in the clutch (Tables 
4.2 and 4.3). Females across all fat ranges laid eggs of similar mass, protein, and fat throughout their clutches in both years.

First eggs in 2004. - We found no relation between body fat and egg mass, egg protein, or egg fat among first eggs in 2004 across all fat classes (Tables 4.3 and 4.4).

First eggs between years. - We found no significant relation in egg mass, protein, or fat in first eggs between years across all condition classes (Tables 4.3 and 4.5). First egg mass was higher in 2004 in the $10-14 \%$ fat class $\left(F_{1,79}=5.70, P=0.019\right)$. Egg protein was different between years in only the $25-29 \%$ class $\left(F_{1,77}=9.01, P=0.004\right.$; Table 4.3$)$, where first eggs were higher in protein content in 2004. Egg fat content in first eggs was also higher in 2004 in the $15-19 \%$ fat class $\left(F_{1,79}=8.16, P=0.006\right)$. Despite these compositional differences within individual classes, we found no discernable trend with regards to fat condition positively or negatively affecting egg mass, egg protein, or egg fat.

Interclutch comparison in 2005. - We found no interclutch (not nested by female) variation in egg composition in first and sixth eggs across all fat condition classes (Tables 4.3 and 4.6).

\section{Egg production}

We collected data from 103 clutches of $\geq 1$ eggs, including chick mass from 41 clutches that produced $\geq 1$ chick. We found no relation between fat condition of females and mean egg mass or clutch size (Tables 4.7 and 4.8). Onset of laying differed between years; females in 2004 laid earlier (Tables 4.7 and 4.8). Females in 15-19 and 20-24\% fat classes laid eggs before other classes in 2004, and the 25-29\% class laid earlier than the 5-9, 10-14, 15-19, and 30+\% fat classes in 2005 (Table 4.8). In both years, the 5-9\% class had the latest onset date (Table 4.8). Notably the $0-4 \%$ class, which was only represented in 2004 , had a late onset as well (Table 
4.8). We found no relation between female body fat and mean chick mass at hatch (Tables 4.7

and 4.8). Female pre- and post-laying fat were positively correlated $\left(r_{s}=0.659, P \leq 0.001\right)$.

\section{DISCUSSION}

Past research on galliform reproductive ecology has shown egg mass to be more a function of heredity and female size than nutritional or body condition (Breitenbach et al. 1963, Labisky and Jackson 1969, Moss and Watson 1982, Naylor and Bendell 1989, Giuliano et al. 1996). Our finding that mean egg mass per clutch differed in only one fat class between years supports previous conclusions that egg mass is not related to fat condition. Consistent egg mass coupled with the fact that we found no evidence that egg composition declines as successive eggs are laid suggests that females are partitioning resources equally throughout their clutch.

Because supernumerary laying was exhibited by some females we examined clutch sizes that far exceeded what is considered normal for wild grouse, and we still found no significant declines in egg composition as successive eggs were laid (one egg was the 26th clutch egg in 2004). This would suggest that egg composition through time does not deteriorate through a 1012 egg clutch for ruffed grouse in varied planes of fat condition. In 2005, only one fat class differed in egg protein (25-29\% class) and egg fat (25-29\% class) in first eggs, thus our findings did not show a specific trend to which fat condition positively or negatively effects any one egg parameter to a large extent, especially considering there were no fat classes that affected sixthlaid eggs for this year. Under nutritional constraint, birds with relatively little fat reserve can partition necessary amino acids from skeletal muscle to provide energy during egg development (Klasing 1998). Beckerton and Middleton (1982) demonstrated that essential amino acid (protein) deficiencies led to smaller eggs and clutches in captive ruffed grouse. Long (2007) found that Appalachian grouse consumed acorns almost exclusively when available, and 
discussed how such cases would lead to a diet very high in metabolizable energy and low in dietary protein. Reduced egg size or clutch size could be possible under such circumstances according to Beckerton and Middleton (1982), but were not encountered in this study, indicating our rations should have fulfilled minimum protein requirements for breeding female grouse.

Egg fat, primarily represented by the yolk, is synthesized by the liver days prior to ovulation and requires essential fatty acids (EFA) for formation. Klasing (1998) reports that EFA deficiencies are rare in Galliformes foraging on natural foods, and commercial feed (as used in this study along with test rations) should meet minimum daily requirements. Yolk lipids (e.g., triglycerides, egg fat) are critical in supplying up to $90 \%$ of the energy for developing precocial chicks prior to hatch (Klasing 1998). Our experimental rations appeared to provide adequate EFA's for females to produce quality eggs and clutches. Unlike altricial species, female grouse must produce young capable of leaving a nest only hours after hatching. It does not seem feasible from a metabolic standpoint for a female to waste energy on an inferior egg (thus jeopardizing chick quality), and if present in a population, the creation of poor eggs would most likely be a trait selected against though evolutionary mechanisms.

It is likely that photoperiod and year-to-year climatic variations largely determine onset of laying in ruffed grouse rather than any particular condition parameter (Meijer and Drent 1999). A review of the "capitol vs. income" theory in breeding birds led Meijer and Drent (1999) to conclude that initiation of laying is not directly related to female energetics. They also reported that in avian food (energy) supplementation studies, onset of laying often begins earlier but does not lead to increased reproductive capacity. Since follicular hypertrophy begins 6-8 weeks before laying begins, females begin the metabolically-expensive process of reproduction long before eggs are laid, which indicates that laying is not a last-minute decision on behalf of 
the female but rather a long and calculated physiological response to spring climatic conditions that usually dictate nutritional conditions and thus fat condition (Williams 2005). We found that our leaner females (0-9\% fat) began laying eggs later than birds with $>9 \%$ body fat. This may suggest that females having higher fat condition leading up to breeding may be physiologically able to lay eggs prior to birds with less body fat, although Dobony (2000) found a maximum range of only 11 days between earliest and latest hatch dates in West Virginia. Long (2007) found that in areas where wild female Appalachian grouse were in poorer fat condition $(<11 \%$ body fat), females demonstrated delayed nesting and lower chick survival to 5-weeks post-hatch than areas where grouse were in moderate to high body fat levels ( $>11 \%$ body fat). These combined results may indicate a critical threshold for body fat condition and timing of laying in female ruffed grouse.

Clutch size in ruffed grouse has been well documented since the mid 1900s (Bump et al. 1947, Edminster 1947), and literature provides no evidence that wild ruffed grouse lay supernumerary eggs, suggesting fat condition plays little to no role in determining clutch size. Chick mass at hatch $(11.6 \pm 0.2 \mathrm{~g}, 9.0-15.3)$ did not provide evidence of a relation to female fat condition. Smith (2006) reported a mean chick mass of $14.7 \mathrm{~g}(9.8-21.2)$ for wild-caught ruffed grouse chicks 2-4 days post hatch in the central and southern Appalachians. Chick mass at hatch in this study was consistent with these reports, although the latter study used methods assessing chick mass 2-4 days after chicks were weighed in this study. Higher variation and heavier chick masses found by Smith (2006) are likely due to the additional 2-4 days of growth and gastrointestinal fill from having time to establish foraging behavior. Given that egg size is determinate once produced (and thus chick mass) and has been reported to be more a function of female size and heredity than nutritional or body condition, results from this study indicate that 
in the Appalachians egg size and subsequent chick hatch mass are fixed parameters across varying nutritional planes. We could not demonstrate that any Appalachian ruffed grouse females attempt to invest more energy into their eggs than what is necessary. From an evolutionary perspective, investing a perfect balance of energy into producing a viable clutch of eggs would serve a species well; any additional energy invested above what is needed would seem wasted. Previous hypotheses suggested that reduced productivity in Appalachian grouse could result from site-specific and habitat-specific constraints on nutritional and body condition (Smith 2006, Long 2007).

It is feasible that lowered productivity and population numbers in the Appalachians is related to female condition and subsequent ability to rear chicks post-hatch. A grouse female in suboptimal condition could be limited in her ability to brood chicks or keep a brood together during foraging, which could negatively impact survival or chick growth. This study suggests that all female Appalachian ruffed grouse possess similar reproductive capacities; any detrimental effects that body condition has on productivity must be expressed after the nesting effort is complete.

\section{ACKNOWLEDGMENTS}

We thank the West Virginia University Division of Forestry and Natural Resources and the Richard King Mellon Foundation for funding. R. L. Cochrane was generous in allowing us the use of his facility and ruffed grouse and for providing his expertise and insight in maintaining healthy grouse in captivity. Thanks to B. Sparks for data collection and care of the grouse. The West Virginia University Rumen Fermentation Profiling laboratory conducted all proximate analyses. 


\section{LITERATURE CITED}

Aldrich, J. W. 1963. Geographic orientation of American Tetraonidae. Journal of Wildlife Management 27:529-545.

Allen, N. K., and R. J. Young. 1980. Studies on the amino acid and protein requirements of laying Japanese quail (Coturnix coturnix japonica). Poultry Science 59:2029-2037.

Association of Official Analytical Chemists. 1990. Official Methods of Analysis. Fifteenth edition. Association of Official Analytical Chemists, Arlington, VA, USA.

Barber, H. L., F. J. Brenner, R. Kirkpatrick, F. A. Servello, D. F. Stauffer, and F. R. Thompson III. 1989a. The kingdom of the ruffed grouse: food. Pages 268-283 in S. Atwater and J. Schnell, editors. The wildlife series: ruffed grouse. Stackpole Books, Harrisburg, Pennsylvania, USA.

, H. L., R. Chambers, R. Kirkpatrick, J. Kubisiak, F. A. Servello, S. K. Stafford, D. F. Stauffer, and F. R. Thompson. 1989b. Cover. Pages 294-319 in S. Atwater and J. Schnell, editors. The wildlife series: ruffed grouse. Stackpole Books, Harrisburg, Pennsylvania, USA.

Barrett, W. M. 1969. Response of ring-necked pheasants to ecological factors and reduced metabolizable energy levels. Master's Thesis, University of Guelph, Guelph, Ontario, Canada.

Beckerton, P. R., and A. L. A. Middleton. 1982. Effects of dietary protein levels on ruffed grouse reproduction. Journal of Wildlife Management 46:569-579. , and __ 1983. Effects of dietary protein levels on body weight, food consumption, and nitrogen balance in ruffed grouse. Condor 85:53-60. 
Breitenbach, R. P., C. L. Nagra, and R. K. Meyer. 1963. Effect of limited food intake on cyclic annual changes in ring-necked pheasant hens. Journal of Wildlife Management 27:2436.

Bump, G., R. W. Darrow, F. C. Edminster, and W. F. Crissey. 1947. The ruffed grouse: life history, propagation, management. Telegraph Press, Harrisburg, Pennsylvania, USA.

Cain, J. R., R. W. Moore, D. S. Smith, R. J. Lein, and J. W. Lee. 1963. Dietary energy consumption by bobwhite and scaled quail. Poultry Science 60:1632.

Castro, G, B. A. Wunder, and F. L. Knopf. 1990. Total body electrical conductivity (TOBEC) to estimate total body fat of free-living birds. Condor 92:496-499.

Cringan, A. T. 1970. Reproductive biology of ruffed grouse in southern Ontario, 1964-1969. Journal of Wildlife Management 34:756-761.

Der, G., and B. Everitt. 2002. A handbook of statistical analyses using SAS. CRC Press, Boca Raton, Florida, USA.

Dessecker, D. R. 2001. Ruffed grouse. Pages 147-155 in J. G. Dickson, editor. Wildlife of southern forests: habitat and management. Hancock House, Blaine, Washington, USA. and D. G. McAuley. 2001. Importance of early successional habitat to ruffed grouse and American woodcock. Wildlife Society Bulletin 29: 456-465.

Devers, P. K., and D. F. Stauffer. 2004. Ruffed grouse reproduction and productivity in the Appalachian region. Pages 29-31 in G. W. Norman, D. F. Stauffer, J. Sole, T. J. Allen, W. K. Igo, S. Bittner, J. Edwards, R. L. Kirkpatrick, W. M. Giuliano, B. Tefft, C. Harper, D. Buehler, D. Figert, M. Seamster, and D. Swanson, editors. Ruffed grouse ecology and management in the Appalachian region: Final project report of the Appalachian Cooperative Grouse Research Project. Richmond, Virginia, USA. 
2005. Population ecology of and the effects of hunting on ruffed grouse in the southern and central Appalachians. Dissertation, Virginia Tech, USA.

, D. F. Stauffer, G. W. Norman, D. E. Steffen, D. M. Whitaker, J. D. Sole, T. J. Allen, S.

L. Bittner, D. A. Buehler, J. W. Edwards, D. E. Figert, S. T. Friedhoff, W. W. Giuliano,

C. A. Harper, W. K. Igo, R. L. Kirkpatrick, M. H. Seamster, H. A. Spiker, D. A.

Swanson, and B. C. Tefft. Ruffed grouse population ecology in the Appalachian region. 2007. Wildlife Monographs 168.

Dobony, C. A. 2000. Factors influencing ruffed grouse productivity and chick survival in West Virginia. Thesis, West Virginia University, Morgantown, USA.

, J. W. Edwards, W. M. Ford, and T. J. Allen. 2001. Nesting success of ruffed grouse in

West Virginia. Proceedings of the annual conference of the Southeastern Association of Fisheries and Wildlife Agencies 55:456-465.

Doerr, P. D., D. H. Rusch, L. B. Keith, and C. A. Fischer. 1974. Characteristics of winter feeding aggregations of ruffed grouse in Alberta. Journal of Wildlife Management 38:601-615.

Dorney, R. S., and C. Kabat. 1960. Relation of weather, parasitic disease, and hunting to Wisconsin ruffed grouse populations. Wisconsin Conservation Department Technical Bulletin 20.

Edminster, F. C. 1947. The ruffed grouse: its life story, ecology, and management. Macmillan, New York, New York, USA.

EM-SCAN Inc. 1993. EM-SCAN/TOBEC Model SA-3000 Multi-Detector Small Animal Body Composition Analysis System Operator's Manual. EM-SCAN Inc., Springfield, Illinois, USA. 
Giuliano, W. M., R. S. Lutz, and R. Patino. 1996. Reproductive responses of adult female northern bobwhite and scaled quail to nutritional stress. Journal of Wildlife Management 60:302-309.

Gullion, G. W., and F. J. Svoboda. 1972. The basic habitat resource for ruffed grouse. Aspen symposium proceedings, U.S. Forest Service General Technical Report NC-1: 113-119. 1977. Forest manipulation for ruffed grouse. Transactions of the North American Wildlife and Natural Resources Conference 42:449-458.

Haulton, G. S. 1999. Ruffed grouse natality, chick survival, and brood micro-habitat selection in the southern Appalachians. M. S. Thesis, Virginia Tech, Blacksburg, USA.

Hewitt, D. G. 1994. Ruffed grouse nutrition and foraging in the southern Appalachians. Ph. D. Dissertation, Virginia Tech, Blacksburg, USA. , and R. L. Kirkpatrick. 1996. Forage intake rates of ruffed grouse and potential effects on grouse density. Canadian Journal of Zoology 74:2016-2024.

, and _ _ 1997a. Daily activity times of ruffed grouse in southwestern Virginia. Journal of Field Ornithology 68:413-420. , and __ 1997b. Ruffed grouse consumption and detoxification of evergreen leaves. Journal of Wildlife Management 61:129-139.

Hill, F. W., and L. M. Dansky. 1954. Studies of the energy requirements of chickens. I. The effect of dietary energy on growth and feed consumption. Poultry Science 33:112-119. , and D. L. Anderson. 1958. Comparison of metabolizable energy and productive energy determinations with growing chicks. Journal of Nutrition 64:641-648.

Huempfner, R. A., and J. R. Tester. 1988. Winter arboreal feeding behavior of ruffed grouse in east-central Minnesota. Pages 122-127 in A. T. Bergerud and M. W. Gratson, editors. 
Adaptive strategies and population ecology of northern grouse. University of Minnesota Press, Minneapolis, Minnesota, USA.

Irving, L., G. C. West, and L. J. Peyton. 1967. Winter feeding programs of Alaska willow ptarmigan shown by crop contents. Condor 69:69-77.

Johnsgard, P. A. 1983. The grouse of the world. The University of Nebraska Press, Lincoln, USA. 1989. A proud pedigree. Pages 8-14 in S. Atwater and J. Schnell, editors. The wildlife series: ruffed grouse. Stackpole Books, Harrisburg, Pennsylvania, USA.

Johnson, D. H., G. L. Krapu, K. J. Reinecke, and D. G. Jorde. 1985. An evaluation of condition indices for birds. Journal of Wildlife Management 49:569-575.

Jones, B. C., J. L. Kleitch, C. A. Harper, and D. A. Buehler. 2008. Ruffed grouse brood habitat use in a mixed hardwood forest: Implications for forest management in the Appalachians. Forest Ecology and Management 255:3580-3588.

King, J. R. 1973. Energetics of reproduction in birds. Pages 78-107 in D. S. Farner, editor. Breeding Biology of Birds. National Academy of Sciences, Washington, D.C., USA.

Kirkpinar, F., and I. Oguz. 1995. Influence of various dietary protein levels on carcass composition in the male Japanese quail. British Journal of Poultry Science 36:605-610.

Klasing, K. C. 1998. Comparative Avian Nutrition. CABI Publishing, New York, New York, USA.

Koutsos, E. A., K. D. Matson, and K. C. Klasing. 2001. Nutrition of birds in the order Psittaciformes: a review. Journal of Avian Medicine and Surgery 15(4):257-275.

Labisky, R. F., and G. L. Jackson. 1969. Production and weights of eggs laid by yearling, 2-, and 3-year old pheasants. Journal of Wildlife Management 33:718-721. 
Larson, M. A. 1998. Nesting success and chick survival of ruffed grouse (Bonasa umbellus) in northern Michigan. Thesis, Michigan State University, East Lansing, USA. M. E. Clark, and S. R. Winterstein. 2003. Survival and habitat of ruffed grouse nests in northern Michigan. Wilson Bulletin 115:140-147.

Long, C. R., J. Edwards, and W. Giuliano. 2004a. Pre-breeding nutritional condition and potential effects on reproduction. Pages 19-22 in G. W. Norman, D. F. Stauffer, J. Sole, T. J. Allen, W. K. Igo, S. Bittner, J. Edwards, R. L. Kirkpatrick, W. M. Giuliano, B. Tefft, C. Harper, D. Buehler, D. Figert, M. Seamster, and D. Swanson, editors. Ruffed grouse ecology and management in the Appalachian region: Final project report of the Appalachian Cooperative Grouse Research Project. Richmond, Virginia, USA. , and 2004b. Pre-breeding food habits of ruffed grouse in the Appalachian region. Pages 15-18 in G. W. Norman, D. F. Stauffer, J. Sole, T. J. Allen, W. K. Igo, S. Bittner, J. Edwards, R. L. Kirkpatrick, W. M. Giuliano, B. Tefft, C. Harper, D. Buehler, D. Figert, M. Seamster, and D. Swanson, editors. Ruffed grouse ecology and management in the Appalachian region: Final project report of the Appalachian Cooperative Grouse Research Project. Richmond, Virginia, USA. 2007. Pre-breeding food habits and condition of ruffed grouse and effects on productivity in the central and southern Appalachian region. M. S. Thesis, West Virginia University, Morgantown, USA.

Meijer, T., and R. Drent. 1999. Re-examination of the capital and income dichotomy in breeding birds. Ibis 141:399-414.

Morton, J. M., R. L. Kirkpatrick, and E. P. Smith. 1991. Comments on estimating total lipids from measures of lean mass. Condor 93:463-465. 
Moss, R., and A. Watson. 1982. Heritability of egg size, hatch weight, body weight, and viability in red grouse (Lagopus lagopus scoticus). Auk 99:683-686.

National Research Council. 1994. Nutrient requirements of poultry. Ninth edition. National Academy Press, Washington, D. C., USA.

Naylor, B. J., and J. F. Bendell. 1989. Clutch size and egg size of spruce grouse in relation to spring diet, food supply, and endogenous reserves. Canadian Journal of Zoology 67:969_ 980.

Nestler, R. B., W. W. Bailey, M. J. Rensberger, and M. Y. Benner. 1944. Protein requirements of breeding bobwhite quail. Journal of Wildlife Management 8:284-289.

Norman, G. W., and R. L. Kirkpatrick. 1984. Foods, nutrition, and condition of ruffed grouse in southwestern Virginia. Journal of Wildlife Management 48:183-187.

Pethig, R. 1979. Dielectric and electronic properties of biological materials. Wiley, Chichester.

Runkles, R. R. 1989. The subspecies. Pages 42-47 in S. Atwater and J. Schnell, editors. The wildlife series: ruffed grouse. Stackpole Books, Harrisburg, Pennsylvania, USA.

Rusch, D. H., and L. B. Keith. 1971. Seasonal and annual trends in numbers of Alberta ruffed grouse. Journal of Wildlife Management 35:803-822. , and S. DeStafano. 1989. To tally the grouse. Pages 200 - 206 in S. Atwater and J. Schnell, editors. The wildlife series: ruffed grouse. Stackpole Books, Harrisburg, Pennsylvania, USA.

M. C. Reynolds, and D. Lauten. 2000. Ruffed grouse (Bonasa umbellus). No. 515 in A. Poole and F. Gill, editors. The Birds of North America. The Birds of North America, Inc., Philadelphia, Pennsylvania, USA. 
SAS Institute Inc. 2002-2004. SAS 9.1.3 Help and Documentation. SAS Institute Inc., Cary, North Carolina, USA.

Sauer, J. R., J. E. Hines, and J. Fallon. 2006. The North American Breeding Bird Survey, Results and Analysis 1966-2005. Version 6.2.2006. USGS Patuxent Wildlife Research Center, Laurel, Maryland. (www.mbr-pwrc.usgs.gov/bbs/bbs.html).

Scott, M. L. 1973. Nutrition in reproduction-direct effects and predictive functions. Pages 4677 in D. S. Farner, editor. Breeding biology of birds. National Academy of Science, Washington, D. C., USA.

Scott, I., C. Selman, P. I. Mitchell, and P. R. Evans. 2001. The use of total body electrical conductivity (TOBEC) to determine body composition in vertebrates. Pages $127-160$ in J. R. Speakman, editor. Body composition analysis of animals. Cambridge University Press, New York, New York, USA.

Seehorn, M. E., R. F. Harlow, and M. T. Mengak. 1981. Foods of ruffed grouse from three locations in the southern Appalachian mountains. Proceedings of the Annual Conference of the Southeastern Association of Fish and Wildlife Agencies 35:216-224.

Servello, F. A., and R. L. Kirkpatrick. 1987a. Regional variation in the nutritional ecology of ruffed grouse. Journal of Wildlife Management 51:749-770. and 1987b. Fat indices for ruffed grouse. Journal of Wildlife Management 51:173-177. , and 1988. Nutrition and condition of ruffed grouse during the breeding season in southwestern Virginia. Condor 90:836-842. , and . 1989a. Scarcity in the south. Page 204 in S. Atwater and J. Schnell, editors. The wildlife series: ruffed grouse. Stackpole Books, Harrisburg, Pennsylvania, USA. 
and 1989b. Nutrition. Pages 284-286 in S. Atwater and J. Schnell, editors. The wildlife series: ruffed grouse. Stackpole Books, Harrisburg, Pennsylvania, USA.

Sibbald, I. R. 1980. The effects of dietary cellulose and sand on the combined metabolic plus endogenous every and amino acid outputs of adult cockerels. Poultry Science 59:836844.

. 1981. Metabolic plus endogenous energy and nitrogen losses of adult cockerels: the correction used in the bioassay for true metabolizable energy. Poultry Science 60:805811.

Small, R. J., J. C. Holzwart, and D. H. Rusch. 1996. Natality of ruffed grouse Bonasa umbellus in central Wisconsin, USA. Wildlife Biology 2:49-52.

Smith, B. W., C. Dobony, and J. Edwards. 2004. Survival and cause specific mortality of ruffed grouse chicks in the Appalachians. Pages 27-28 in G. W. Norman, D. F. Stauffer, J.

Sole, T. J. Allen, W. K. Igo, S. Bittner, J. Edwards, R. L. Kirkpatrick, W. M. Giuliano, B. Tefft, C. Harper, D. Buehler, D. Figert, M. Seamster, and D. Swanson, editors. Ruffed grouse ecology and management in the Appalachian region: Final project report of the Appalachian Cooperative Grouse Research Project. Richmond, Virginia, USA. 2006. Nesting ecology, chick survival, and juvenile dispersal of ruffed grouse (Bonasa umbellus) in the Appalachian mountains. Dissertation, West Virginia University, Morgantown, USA.

Snyder, M. V., D. M. Post, and E. J. Finck. 2005. The use of total body electrical conductivity (TOBEC) to predict lean and lipid mass in woodrats. Wildlife Society Bulletin 33:10091017. 
Stafford, S. K., and R. W. Dimmick. 1979. Autumn and winter foods of ruffed grouse in the southern Appalachians. Journal of Wildlife Management 43:121-127.

Stoll, R. J., M. W. McClain, C. M. Nixon, and D. M. Worley. 1980. Foods of ruffed grouse in Ohio. Ohio Department of Natural Resources, Division of Wildlife, Fish and Wildlife Report 7.

Svoboda, F. J., and G. W. Gullion. 1972. Preferential use of aspen by ruffed grouse in northern Minnesota. Journal of Wildlife Management 36:1166-1180.

Thomas, V. G., H. G. Lumsden, and D. H. Price. 1975. Aspects of the winter metabolism of ruffed grouse (Bonasa umbellus) with special reference to energy reserves. Canadian Journal of Zoology 53:434-440.

Thompson, F. R., and E. K. Fritzell. 1986. Fall foods and nutrition of ruffed grouse in Missouri. Transactions of the Missouri Academy of Science 20:45-48.

Tirpak, J. M., W. M. Giuliano, and C. A. Miller. 2008. Ruffed grouse brood habitat selection at multiple scales in Pennsylvania: implications for survival. Canadian Journal of Zoology $86: 329-337$.

Underwood, M. S., D. Polin, P. O’Handley, and P. Wiggers. 1991. Short term ecology and protein utilization by budgerigars fed isocaloric diets of varying protein concentrations. Proceedings of the Annual Conference of the Association of Avian Veterinarians 1991:227-237.

Walsberg, G. E. 1988. Evaluation of a nondestructive method for determining fat stores in small birds and mammals. Physiological Zoology 61:153-159.

Weber, A. J., and F. B. Barick. 1963. Eleven years of ruffed grouse censusing in western North Carolina. Proceedings of the Annual Conference of the Southeast Association of Game 
and Fish Commissioners 17:13-15. Zarr, J. H. 1999. Biostatical analysis. Fourth edition. Prentice-Hall Inc., Upper Saddle River, New Jersey, USA.

West, G. C., and M. S. Meng. 1968. Seasonal changes in body weight and fat and the relation of fatty acid composition to diet in the willow ptarmigan. Wilson Bulletin 80:426-441.

Whitaker, D. M. 2003. Ruffed grouse (Bonasa umbellus) habitat ecology in the central and southern Appalachians. Dissertation, Virginia Tech, Blacksburg, USA. , T. Fearer, S. Haulton, and D. F. Stauffer. 2004. Ruffed grouse habitat selection and home range size in the Appalachian region. Pages 39-44 in G. W. Norman, D. F. Stauffer, J. Sole, T. J. Allen, W. K. Igo, S. Bittner, J. Edwards, R. L. Kirkpatrick, W. M. Giuliano, B. Tefft, C. Harper, D. Buehler, D. Figert, M. Seamster, and D. Swanson, editors. Ruffed grouse ecology and management in the Appalachian region: Final project report of the Appalachian Cooperative Grouse Research Project. Richmond, Virginia, USA.

D. F. Stauffer, G. W. Norman, P. K. Devers, J. Edwards, W. M. Giuliano, C. Harper, W. Igo, J. Sole, H. Spiker, and B. Teft. 2007. Factors associated with variation in homerange size of Appalachian ruffed grouse (Bonasa umbellus). The Auk 124:1407-1424.

Williams, T. D. 2005. Mechanisms underlying the costs of egg production. Bioscience 55:39- 


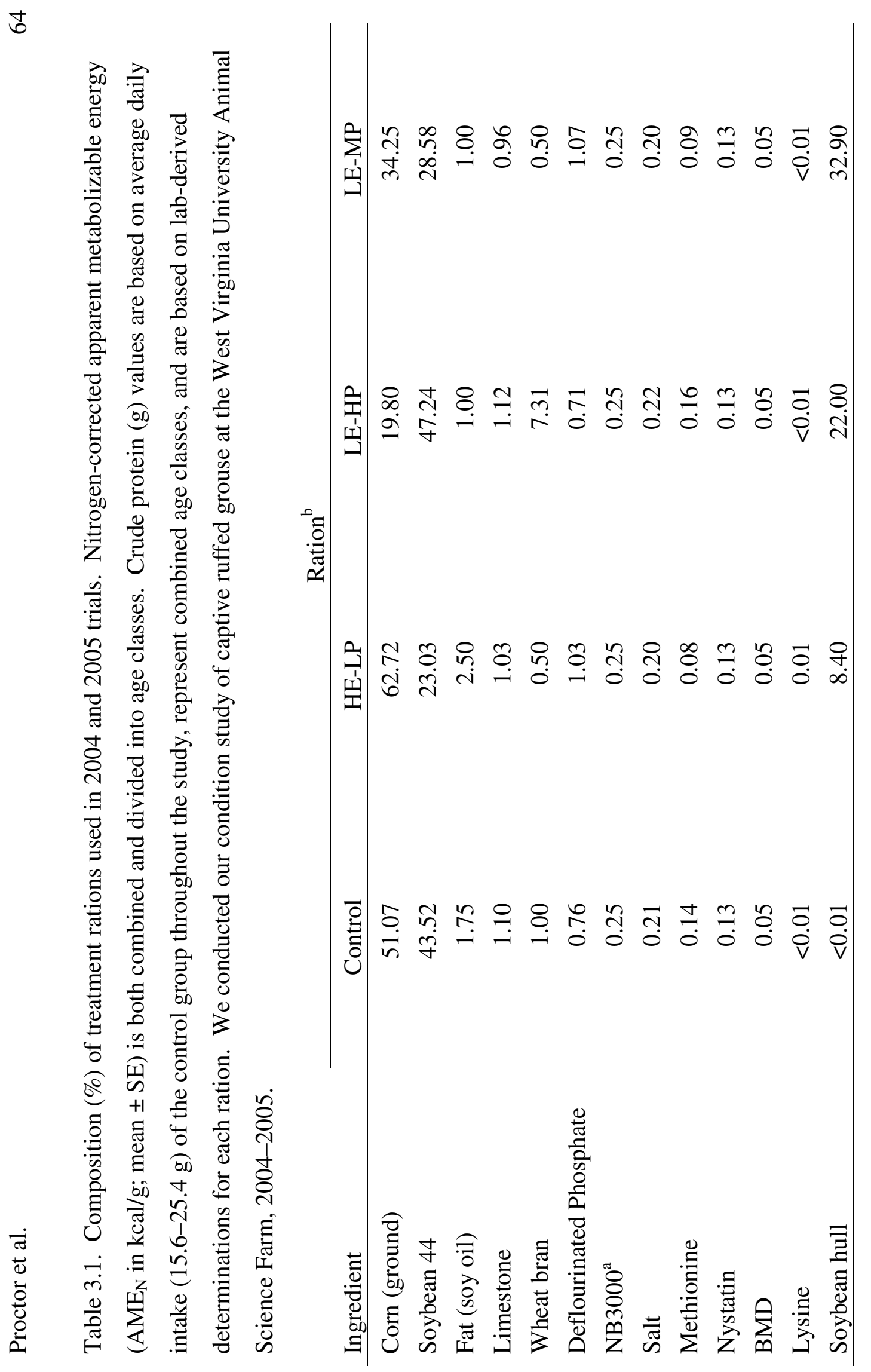




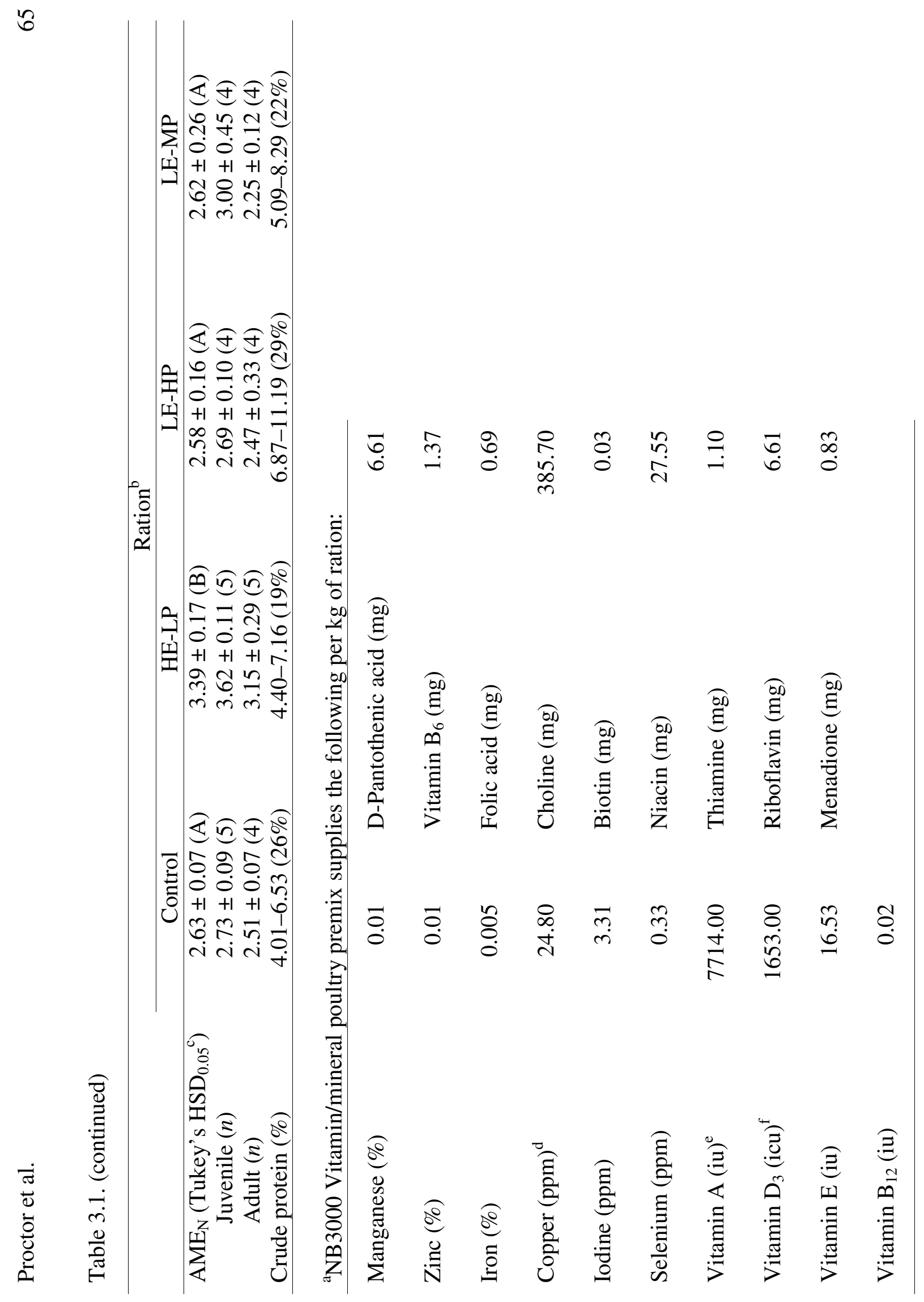




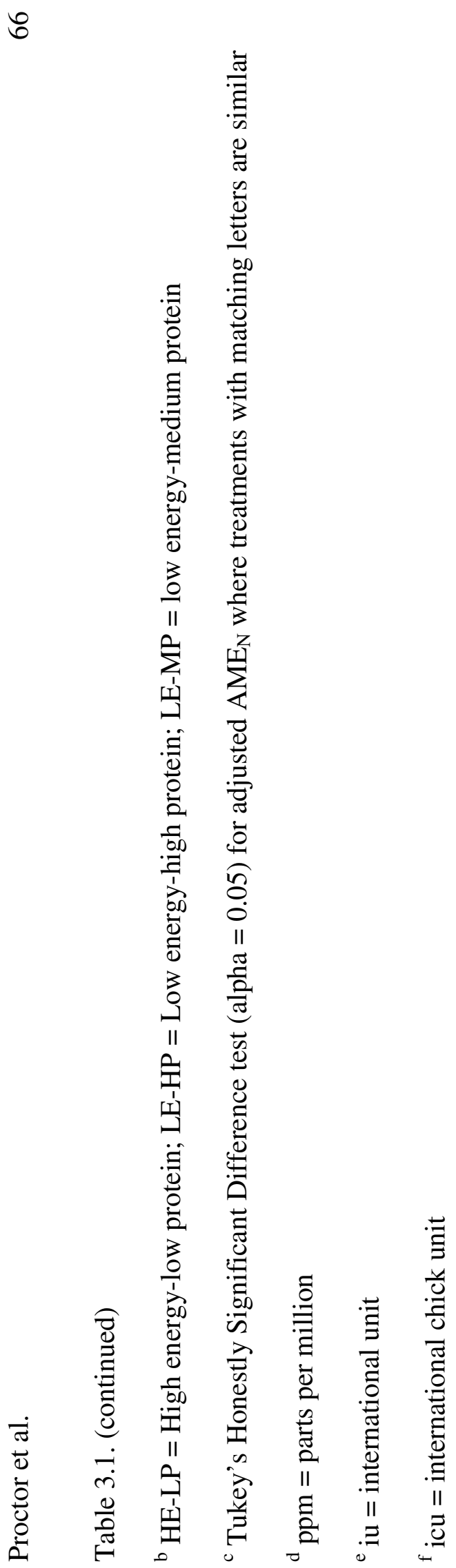




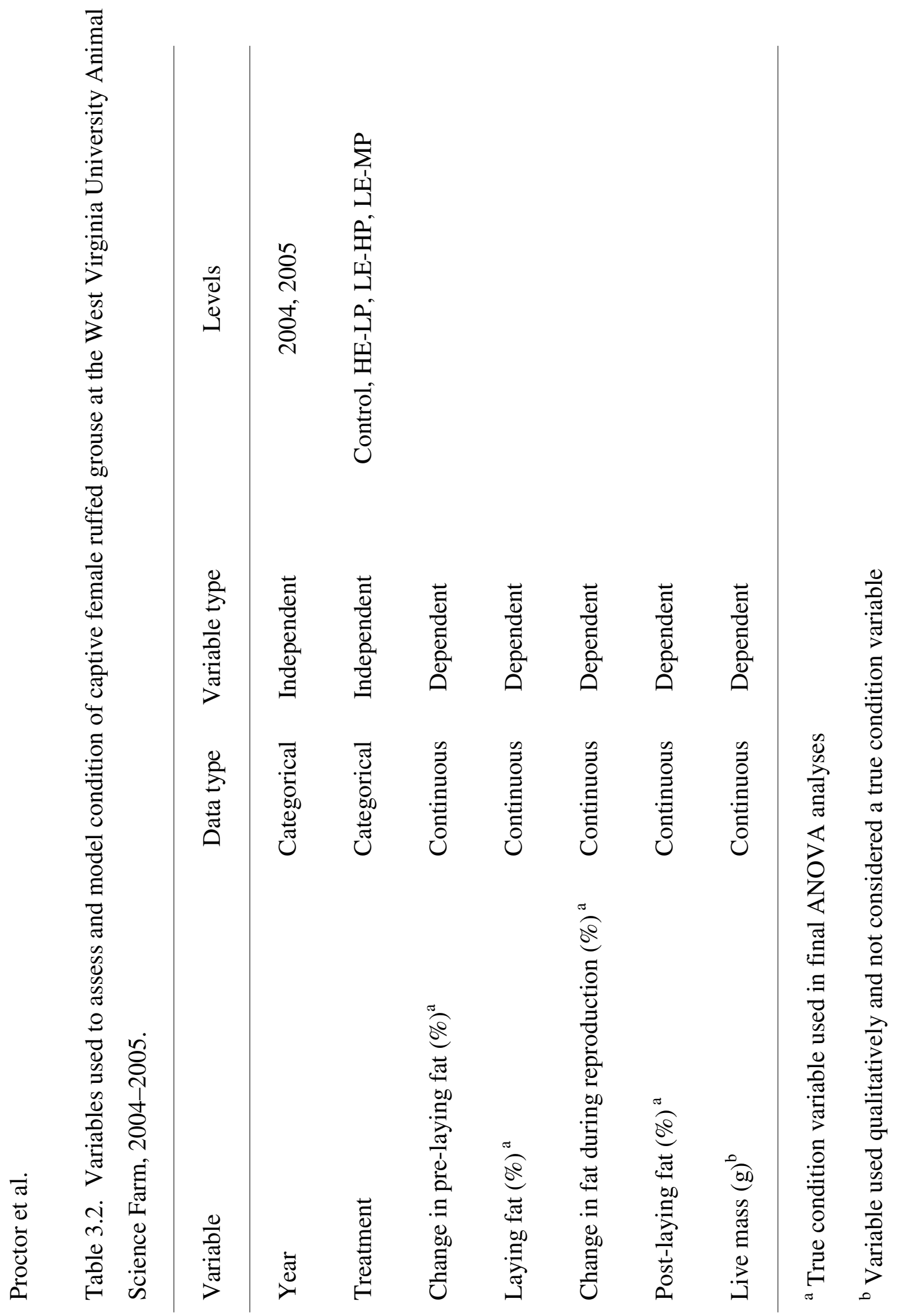




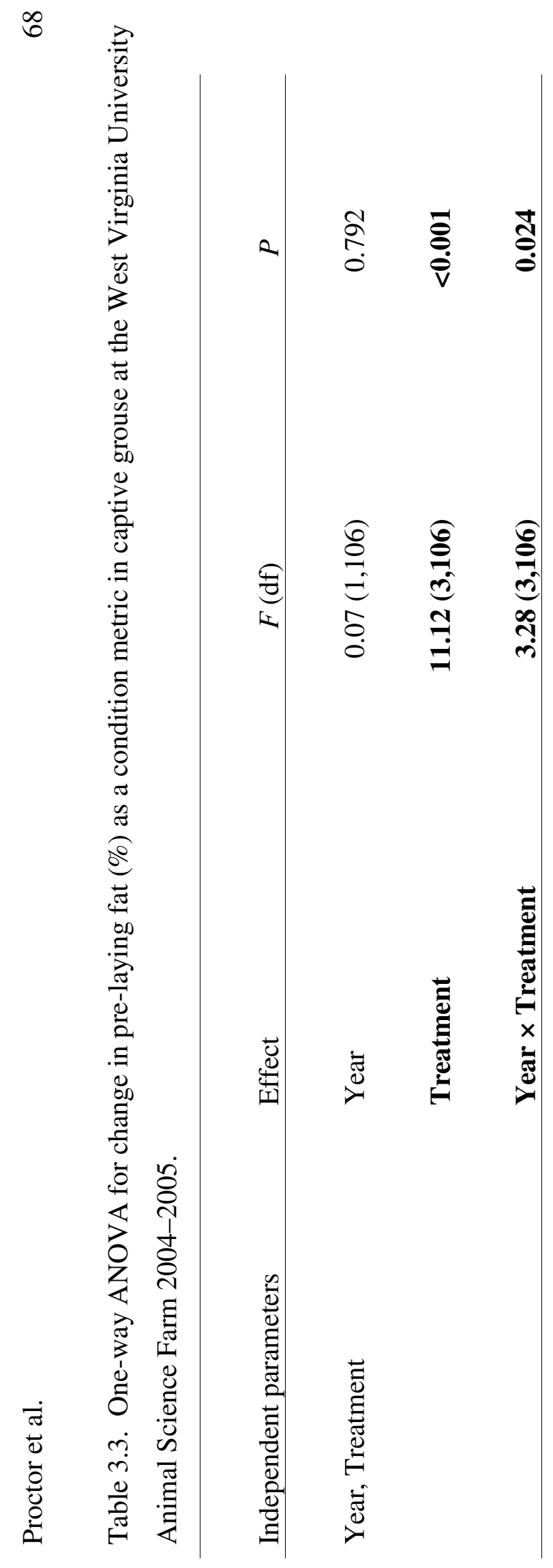


Table 3.4. Change in pre-laying fat (\%; mean \pm SE) among treatment groups of female ruffed grouse at West Virginia University's Animal Science Farm 2004-2005.

\begin{tabular}{|c|c|c|c|c|}
\hline Treatment group & Year & $n$ & Value & Tukey's HSD ${ }_{0.05}{ }^{\mathrm{a}}$ \\
\hline \multirow[t]{3}{*}{ Control } & 2004 & 15 & $5.93 \pm 1.39$ & \\
\hline & 2005 & 13 & $3.76 \pm 1.34$ & \\
\hline & Combined & 28 & $4.92 \pm 0.97$ & $\mathbf{A}$ \\
\hline \multirow[t]{3}{*}{ High energy-low protein } & 2004 & 15 & $6.08 \pm 1.27$ & \\
\hline & 2005 & 16 & $3.04 \pm 1.65$ & \\
\hline & Combined & 31 & $4.51 \pm 1.07$ & $\mathbf{A}$ \\
\hline \multirow[t]{3}{*}{ Low energy-high protein } & 2004 & 12 & $-0.15 \pm 1.19$ & \\
\hline & 2005 & 14 & $-0.51 \pm 0.99$ & \\
\hline & Combined & 26 & $-0.35 \pm 0.75$ & B \\
\hline \multirow[t]{3}{*}{ Low energy-medium protein } & 2004 & 14 & $-3.34 \pm 1.23$ & \\
\hline & 2005 & 15 & $1.07 \pm 1.26$ & \\
\hline & Combined & 29 & $-1.05 \pm 0.96$ & $\mathbf{B}$ \\
\hline
\end{tabular}

a Tukey's honestly significant difference test $($ alpha $=0.05)$ where treatments with matching letters are similar 
Table 3.5. One-way ANOVA for laying fat (\%) as a condition metric in captive grouse at the West Virginia University Animal Science Farm, 2004-2005.

Independent parameters

Year, Treatment

Year

Treatment

Year $\times$ Treatment
$F(\mathrm{df})$

$18.52(1,109)$

$<0.001$

$4.44(3,109)$

0.006

P

$2.65(3,109)$


Table 3.6. Laying fat (\%; mean \pm SE) among treatment groups of female ruffed grouse at West Virginia University's Animal Science Farm, 2004-2005.

\begin{tabular}{|c|c|c|c|c|}
\hline Parameter & Year & $n$ & Value & Tukey's $\mathrm{HSD}_{0.05}{ }^{\mathrm{a}}$ \\
\hline \multirow[t]{3}{*}{ Control } & 2004 & 15 & $15.62 \pm 1.63$ & \\
\hline & 2005 & 13 & $18.86 \pm 1.69$ & \\
\hline & Combined & 28 & $17.13 \pm 1.19$ & A, B \\
\hline \multirow[t]{3}{*}{ High energy-low protein } & 2004 & 15 & $17.46 \pm 2.00$ & \\
\hline & 2005 & 16 & $19.69 \pm 2.67$ & \\
\hline & Combined & 31 & $18.61 \pm 1.67$ & $\mathbf{A}$ \\
\hline \multirow[t]{3}{*}{ Low energy-high protein } & 2004 & 13 & $11.19 \pm 1.05$ & \\
\hline & 2005 & 15 & $15.27 \pm 1.16$ & \\
\hline & Combined & 28 & $13.38 \pm 0.87$ & B \\
\hline \multirow[t]{3}{*}{ Low energy-medium protein } & 2004 & 15 & $9.69 \pm 1.14$ & \\
\hline & 2005 & 15 & $19.14 \pm 1.32$ & \\
\hline & Combined & 30 & $14.41 \pm 1.23$ & A, B \\
\hline \multirow[t]{2}{*}{ Year } & 2004 & 58 & $13.57 \pm 0.86$ & $\mathbf{A}$ \\
\hline & 2005 & 59 & $18.24 \pm 0.93$ & $\mathbf{B}$ \\
\hline
\end{tabular}

a Tukey’s honestly significant difference test $($ alpha $=0.05)$ where treatments with matching letters are similar 
Table 3.7. One-way ANOVA for change in fat (\%) during reproduction as a condition metric in captive grouse at West University Animal Research Farm, 2004-2005.

\begin{tabular}{llll}
\hline & & & \\
Independent parameters & Effect & $F(\mathrm{df})$ & \\
\hline Year, Treatment & Year & $\mathbf{4 . 9 5}(\mathbf{1 , 8 8})$ & $\mathbf{0 . 0 2 9}$ \\
& Treatment & $1.17(3,88)$ & 0.325 \\
& & & \\
& Year $\times$ Treatment & $1.65(3,88)$ & 0.183 \\
\hline
\end{tabular}


Table 3.8. Change in fat during reproduction (\%; mean \pm SE) among treatment groups of female ruffed grouse at West Virginia University's Animal Science Farm, 2004-2005.

\begin{tabular}{|c|c|c|c|}
\hline Parameter & Year & $n$ & Value \\
\hline \multirow[t]{2}{*}{ Control } & 2004 & 14 & $-5.15 \pm 2.06$ \\
\hline & 2005 & 11 & $-3.49 \pm 1.15$ \\
\hline \multirow[t]{2}{*}{ High energy-low protein } & 2004 & 12 & $-3.49 \pm 1.57$ \\
\hline & 2005 & 16 & $-6.90 \pm 2.09$ \\
\hline \multirow[t]{2}{*}{ Low energy-high protein } & 2004 & 12 & $-1.59 \pm 0.91$ \\
\hline & 2005 & 9 & $-6.23 \pm 1.32$ \\
\hline \multirow[t]{2}{*}{ Low energy-medium protein } & 2004 & 10 & $0.57 \pm 0.99$ \\
\hline & 2005 & 12 & $-4.78 \pm 1.23$ \\
\hline
\end{tabular}


Table 3.9. One-way ANOVA for post-laying percent fat (\%) of captive grouse 2-weeks after termination of laying at West University Animal Research Farm, 2004-2005.

\begin{tabular}{lllc}
\hline & & & \\
Independent parameters & Effect & $F(\mathrm{df})$ & \\
\hline & Year & $\mathbf{4 . 7 0}(\mathbf{1 , 9 0})$ & $\mathbf{0 . 0 3 3}$ \\
& & & \\
Tear, Treatment & Treatment & $1.57(3,90)$ & 0.203 \\
& Year $\times$ Treatment & $1.35(3,90)$ & 0.264 \\
\hline
\end{tabular}


Table 3.10. Post-laying fat (\%; mean \pm SE) of female ruffed grouse at West Virginia University’s Animal Sciences Farm, 2004-2005.

\begin{tabular}{llcc}
\hline Year & $n$ & Percent fat & Tukey's HSD $_{0.05}{ }^{\mathrm{a}}$ \\
\hline $\mathbf{2 0 0 4}$ & $\mathbf{4 8}$ & $\mathbf{1 0 . 9 3} \pm \mathbf{0 . 6 1}$ & $\mathbf{A}$ \\
$\mathbf{2 0 0 5}$ & $\mathbf{5 0}$ & $\mathbf{1 3 . 1 2} \pm \mathbf{0 . 7 2}$ & $\mathbf{B}$ \\
\hline
\end{tabular}

a Tukey's honestly significant difference test $($ alpha $=0.05)$ where treatments with matching letters are similar 
Table 3.11. One-way ANOVA for pre-laying body mass ( $\mathrm{g}$ ) at onset of laying in captive grouse at West University Animal Research Farm, 2004-2005.

Independent parameters

Effect

$F(\mathrm{df})$

$P$

Year, Treatment

Year

$2.99(1,109)$

0.087

Treatment

$4.31(3,109)$

0.007

Year $\times$ Treatment

$3.07(3,109)$

0.031 
Table 3.12. Treatment effect on pre-laying body mass (g; mean \pm SE) of female ruffed grouse at West Virginia University’s Animal Science Farm, 2004-2005.

\begin{tabular}{|c|c|c|c|c|}
\hline Treatment group & Age class & $n$ & Mass & Tukey's HSD $_{0.05}{ }^{\mathrm{a}}$ \\
\hline \multirow[t]{3}{*}{ Control } & 2004 & 15 & $558.13 \pm 13.15$ & \\
\hline & 2005 & 13 & $562.02 \pm 12.50$ & \\
\hline & Combined & 28 & $559.94 \pm 8.97$ & $\mathbf{A}$ \\
\hline \multirow[t]{3}{*}{ High energy-low protein } & 2004 & 15 & $559.67 \pm 12.51$ & \\
\hline & 2005 & 16 & $556.00 \pm 15.65$ & \\
\hline & Combined & 31 & $557.78 \pm 9.93$ & A, B \\
\hline \multirow[t]{3}{*}{ Low energy-high protein } & 2004 & 13 & $526.71 \pm 11.93$ & \\
\hline & 2005 & 15 & $526.67 \pm 8.37$ & \\
\hline & Combined & 28 & $526.69 \pm 6.99$ & $\mathbf{A}, \mathbf{B}$ \\
\hline \multirow[t]{3}{*}{ Low energy-medium protein } & 2004 & 15 & $493.06 \pm 15.39$ & \\
\hline & 2005 & 15 & $556.77 \pm 12.26$ & \\
\hline & Combined & 30 & $524.92 \pm 11.34$ & $\mathbf{B}$ \\
\hline
\end{tabular}

a Tukey's honestly significant difference test $($ alpha $=0.05)$ where treatments with matching letters are similar 
Table 4.1. Independent and dependent variables used to assess female ruffed grouse condition and reproduction at West Virginia University Animal Sciences Farm 2004-2005.

\begin{tabular}{llcl}
\hline Variable & Data type & Variable type & Notes \\
\hline Age class & Categorical & Independent & Juvenile, adult \\
Year & Categorical & Independent & 2004, 2005 \\
Body fat $(\%)$ & Categorical & Dependent & 0-40+ \%, in 5\% classes \\
Clutch onset & Continuous & Dependent & Date \\
Egg protein $(\%)$ & Continuous & Dependent & \\
Egg fat $(\%)$ & Continuous & Dependent & \\
Egg mass $(\mathrm{g})$ & Continuous & Dependent & \\
Clutch size & Continuous & Dependent & \\
& & &
\end{tabular}


Table 4.2. One-way ANOVA for intraclutch variation in egg composition (nested by female) tested using percent body fat as a condition metric in captive female ruffed grouse at the West Virginia University Animal Sciences Farm 2004-2005. For 2004, first, middle, and last-laid eggs were used. For 2005, first and sixth-laid eggs were used in analysis. Values can be found in Table 4.3.

\begin{tabular}{llcc}
\hline Year & $\begin{array}{l}\text { Dependent } \\
\text { parameter }\end{array}$ & $F(\mathrm{df})$ & $P$ \\
\hline 2004 & Egg mass & $1.30(5,32)$ & 0.283 \\
& & & \\
& Egg protein & $1.06(5,32)$ & 0.394 \\
& & & 0.351 \\
& Egg fat & $1.15(5,32)$ & 0.847 \\
& Egg mass & $0.34(4,13)$ & 0.142 \\
& Egg protein & $1.83(4,13)$ & 0.543 \\
\hline
\end{tabular}


Table 4.3. Mean mass, percent protein, and percent fat of eggs tested with one-way ANOVA using percent body fat as a condition metric in captive female ruffed grouse at the West Virginia University Animal Sciences Farm 2004-2005. Body fat is a range (\%). Clutch egg is sequential egg position within clutch.

\begin{tabular}{|c|c|c|c|c|c|c|}
\hline Year & $\begin{array}{l}\% \text { Body } \\
\text { fat }\end{array}$ & $\begin{array}{l}\text { Clutch } \\
\text { egg }^{\mathrm{a}}\end{array}$ & $n$ & $\operatorname{Egg}$ mass $(\mathrm{g})$ & Egg protein $(\%)$ & Egg fat $(\%)$ \\
\hline \multirow[t]{8}{*}{2004} & $0-4$ & First & 3 & $16.84 \pm 0.86$ & $43.63 \pm 0.94$ & $40.44 \pm 0.66$ \\
\hline & & Last & 2 & $17.30 \pm 0.08$ & $45.74 \pm 2.78$ & $39.01 \pm 0.87$ \\
\hline & $5-9$ & First & 11 & $15.96 \pm 0.58$ & $43.39 \pm 0.49$ & $40.49 \pm 0.60$ \\
\hline & & Middle & 5 & $16.79 \pm 0.95$ & $46.31 \pm 1.29$ & $38.95 \pm 1.11$ \\
\hline & & Last & 4 & $16.61 \pm 0.39$ & $45.96 \pm 0.83$ & $40.94 \pm 0.73$ \\
\hline & $10-14$ & First & 19 & $16.57 \pm 0.42$ & $43.98 \pm 0.54$ & $40.16 \pm 0.54$ \\
\hline & & Middle & 8 & $15.78 \pm 0.45$ & $45.41 \pm 0.88$ & $40.18 \pm 0.76$ \\
\hline & & Last & 8 & $16.09 \pm 0.35$ & $45.08 \pm 0.88$ & $40.59 \pm 1.00$ \\
\hline
\end{tabular}

${ }^{\text {a }}$ In 2004, first, middle, and last eggs from clutches were analyzed. In 2005, first and sixth eggs were analyzed. 
Table 4.3. (continued).

\begin{tabular}{|c|c|c|c|c|c|c|}
\hline Year & $\begin{array}{l}\% \text { Body } \\
\text { fat }\end{array}$ & $\begin{array}{l}\text { Clutch } \\
\text { egg }^{\mathrm{a}}\end{array}$ & $n$ & Egg mass $(\mathrm{g})$ & Egg protein $(\%)$ & Egg fat (\%) \\
\hline \multirow[t]{8}{*}{2004} & $15-19$ & First & 11 & $17.71 \pm 0.41$ & $44.83 \pm 0.42$ & $39.57 \pm 0.50$ \\
\hline & & Middle & 4 & $15.84 \pm 0.99$ & $46.04 \pm 0.50$ & $40.44 \pm 0.69$ \\
\hline & & Last & 7 & $16.95 \pm 0.53$ & $45.04 \pm 0.48$ & $40.42 \pm 0.53$ \\
\hline & $20-24$ & First & 3 & $16.92 \pm 0.22$ & $43.06 \pm 1.27$ & $42.38 \pm 1.28$ \\
\hline & & Middle & 1 & 17.66 & 43.42 & 41.25 \\
\hline & & Last & 2 & $16.81 \pm 0.18$ & $44.08 \pm 0.72$ & $41.83 \pm 0.33$ \\
\hline & $25+$ & First & 2 & $15.81 \pm 1.04$ & $44.44 \pm 0.93$ & $41.48 \pm 0.21$ \\
\hline & & Middle & 2 & $15.52 \pm 0.21$ & $42.06 \pm 1.47$ & $41.55 \pm 1.79$ \\
\hline
\end{tabular}

${ }^{a}$ In 2004, first, middle, and last eggs from clutches were analyzed. In 2005, first and sixth eggs were analyzed. 
Table 4.3. (continued).

\begin{tabular}{|c|c|c|c|c|c|c|}
\hline Year & $\begin{array}{l}\% \text { Body } \\
\text { fat }\end{array}$ & $\begin{array}{l}\text { Clutch } \\
\mathrm{egg}^{\mathrm{a}}\end{array}$ & $n$ & Egg mass (g) & Egg protein $(\%)$ & Egg fat $(\%)$ \\
\hline \multirow[t]{10}{*}{2005} & $10-14$ & First & 12 & $17.30 \pm 0.44$ & $44.27 \pm 0.53$ & $40.03 \pm 0.59$ \\
\hline & & Sixth & 4 & $16.42 \pm 1.11$ & $46.45 \pm 0.88$ & $37.81 \pm 0.76$ \\
\hline & $15-19$ & First & 11 & $15.69 \pm 0.61$ & $46.04 \pm 1.02$ & $37.57 \pm 1.18$ \\
\hline & & Sixth & 6 & $15.81 \pm 0.50$ & $46.34 \pm 1.30$ & $40.34 \pm 1.89$ \\
\hline & $20-24$ & First & 8 & $15.87 \pm 0.67$ & $44.62 \pm 1.03$ & $39.64 \pm 1.04$ \\
\hline & & Sixth & 8 & $15.64 \pm 0.42$ & $45.52 \pm 0.41$ & $38.31 \pm 0.95$ \\
\hline & $25-29$ & First & 6 & $16.79 \pm 0.79$ & $42.71 \pm 0.79$ & $41.17 \pm 0.91$ \\
\hline & & Sixth & 2 & $16.96 \pm 0.89$ & $42.93 \pm 0.91$ & $39.30 \pm 0.69$ \\
\hline & $30+$ & First & 2 & $16.65 \pm 0.96$ & $44.14 \pm 1.49$ & $39.49 \pm 0.17$ \\
\hline & & Sixth & 1 & 15.90 & 44.12 & 34.50 \\
\hline
\end{tabular}

${ }^{a}$ In 2004, first, middle, and last eggs from clutches were analyzed. In 2005, first and sixth eggs were analyzed. 
Table 4.4. One-way ANOVA for variation in first egg composition in 2004 tested using percent body fat condition as a condition metric in captive female ruffed grouse at the West Virginia University Animal Sciences Farm 2004-2005. Values can be found in Table 4.3.

\begin{tabular}{llcc}
\hline $\begin{array}{l}\text { Independent } \\
\text { variable }\end{array}$ & $\begin{array}{l}\text { Dependent } \\
\text { variable }\end{array}$ & $F(\mathrm{df})$ & $P$ \\
\hline Laying fat & Egg mass & $1.15(5,43)$ & 0.347 \\
& Egg protein & $0.23(5,43)$ & 0.947 \\
& Egg fat & $0.69(5,43)$ & 0.637 \\
\hline
\end{tabular}


Table 4.5. One-way ANOVA for variation in first egg composition between 2004 and 2005 tested using percent body fat condition as a condition metric in captive female ruffed grouse at the West Virginia University Animal Sciences Farm 2004-2005. Values can be found in Table 4.3 .

\begin{tabular}{|c|c|c|c|c|}
\hline $\begin{array}{l}\text { Independent } \\
\text { variable }\end{array}$ & $\begin{array}{l}\text { Dependent } \\
\text { variable }\end{array}$ & Model & $F(\mathrm{df})$ & $P$ \\
\hline \multirow[t]{9}{*}{ Laying fat } & Egg mass & Laying fat & $0.30(6,79)$ & 0.937 \\
\hline & & Year & $0.43(1,79)$ & 0.514 \\
\hline & & Year $\times$ Laying fat & $1.47(3,79)$ & 0.229 \\
\hline & Egg protein & Laying fat & $0.47(6,79)$ & 0.828 \\
\hline & & Year & $1.13(1,79)$ & 0.291 \\
\hline & & Year $\times$ Laying fat & $0.50(3,79)$ & 0.686 \\
\hline & Egg fat & Laying fat & $0.41(6,79)$ & 0.868 \\
\hline & & Year & $2.15(1,79)$ & 0.146 \\
\hline & & Year $\times$ Laying fat & $0.81(3,79)$ & 0.494 \\
\hline
\end{tabular}


Table 4.6. One-way ANOVA for variation in egg composition of first and sixth-clutch eggs across independent parameters in 2005 tested using percent body fat condition as a condition metric in captive female ruffed grouse at the West Virginia University Animal Sciences Farm 2004-2005. Values can be found in Table 4.3.

\begin{tabular}{|c|c|c|c|c|}
\hline $\begin{array}{l}\text { Independent } \\
\text { variable }\end{array}$ & $\begin{array}{l}\text { Clutch } \\
\text { egg }\end{array}$ & $\begin{array}{l}\text { Dependent } \\
\text { variable }\end{array}$ & $F(\mathrm{df})$ & $P$ \\
\hline \multirow[t]{6}{*}{ Laying fat } & 1 & Egg mass & $0.48(4,36)$ & 0.748 \\
\hline & & Egg protein & $1.14(4,36)$ & 0.353 \\
\hline & & Egg fat & $0.93(4,36)$ & 0.457 \\
\hline & 6 & Egg mass & $0.21(4,17)$ & 0.929 \\
\hline & & Egg protein & $1.28(4,17)$ & 0.317 \\
\hline & & Egg fat & $0.50(4,17)$ & 0.739 \\
\hline
\end{tabular}


Table 4.7. One-way ANOVA for egg production and mean chick hatch mass per female tested using percent body fat condition as a condition metric in captive female ruffed grouse at the West Virginia University Animal Sciences Farm 2004-2005. Year was a fixed parameter in all tests. Values are shown in Table 4.8.

\begin{tabular}{|c|c|c|c|c|}
\hline $\begin{array}{l}\text { Independent } \\
\text { parameter }\end{array}$ & $\begin{array}{l}\text { Dependent } \\
\text { parameter }\end{array}$ & Model effect & $F(\mathrm{df})$ & $P$ \\
\hline \multirow[t]{11}{*}{ Laying fat } & Mean egg mass & Laying fat & $0.55(6,92)$ & 0.583 \\
\hline & & Year & $0.87(1,92)$ & 0.833 \\
\hline & & Year $\times$ Laying fat & $0.81(3,92)$ & 0.490 \\
\hline & Clutch size & Laying fat & $1.13(6,92)$ & 0.349 \\
\hline & & Year & $1.26(1,92)$ & 0.264 \\
\hline & & Year $\times$ Laying fat & $0.25(3,92)$ & 0.860 \\
\hline & Laying onset & Laying fat & $2.57(6,92)$ & 0.024 \\
\hline & & Year & $11059.80(1,92)$ & $\leq 0.001$ \\
\hline & & Year $\times$ Laying fat & $0.48(3,92)$ & 0.700 \\
\hline & Mean chick mass & Laying fat & $0.63(5,32)$ & 0.676 \\
\hline & & Year & $1.60(1,32)$ & 0.215 \\
\hline & & Year $\times$ Laying fat & $0.23(2,32)$ & 0.798 \\
\hline
\end{tabular}


Table 4.8. Values (mean \pm standard error) for ruffed grouse reproduction parameters at West Virginia University Animal Sciences Farm 2004-2005. Laying fat is a range (\%). Egg mass (g) and chick hatch mass $(\mathrm{g})$ were averaged per female $(n)$ prior to analysis.

\begin{tabular}{lllllll}
\hline Year & $\begin{array}{l}\text { Laying } \\
\text { \% fat }\end{array}$ & $n$ & Egg mass & Clutch size & Laying onset $^{\mathrm{a}}$ & ${\text { Chick mass }\left(n_{\mathrm{c}}\right)^{\mathrm{b}}}^{2}$ \\
\hline 2004 & $0-4$ & 3 & $17.87 \pm 0.68$ & $6.67 \pm 2.03$ & 07 May \pm 6.01 & $11.85 \pm 0.75(2)$ \\
& $5-9$ & 12 & $16.22 \pm 0.44$ & $8.00 \pm 1.55$ & 10 May \pm 2.96 & $11.29 \pm 0.38(4)$ \\
& $10-14$ & 20 & $16.61 \pm 0.24$ & $10.20 \pm 1.22$ & 27 April \pm 2.00 & $11.65 \pm 0.40(13)$ \\
& $15-19$ & 11 & $17.59 \pm 0.39$ & $15.82 \pm 2.13$ & 21 April \pm 1.89 & $12.31 \pm 0.30(5)$ \\
& $20-24$ & 3 & $17.32 \pm 0.40$ & $10.33 \pm 2.60$ & 24 April \pm 0.58 & $11.70 \pm 0.44(3)$ \\
& $25+$ & 2 & $16.07 \pm 0.01$ & $9.50 \pm 4.50$ & 29 April \pm 4.00 & $10.44(1)$ \\
& $5-9$ & 1 & 19.70 & 1.00 & 03 May & N/A $(0)$ \\
$10-14$ & 16 & $16.69 \pm 0.39$ & $7.13 \pm 1.50$ & 30 April \pm 3.36 & $11.88 \pm 0.97(3)$ \\
& $15-19$ & 16 & $15.79 \pm 0.31$ & $8.19 \pm 1.76$ & 25 April \pm 2.97 & $10.27 \pm 0.65(3)$ \\
$20-24$ & 10 & $15.78 \pm 0.33$ & $11.10 \pm 2.05$ & 22 April \pm 2.70 & $11.62 \pm 0.33(5)$ \\
$25-29$ & 6 & $17.18 \pm 0.55$ & $6.83 \pm 2.97$ & 20 April \pm 1.72 & $11.94 \pm 0.04$ \\
$30+$ & 2 & $15.62 \pm 0.07$ & $8.50 \pm 5.50$ & 29 April \pm 10.50 & N/A (0)
\end{tabular}

${ }^{\text {a }}$ Mean onset calendar date \pm standard error in days

${ }^{\mathrm{b}} n_{\mathrm{c}}=$ number of clutches resulting in $\geq 1$ hatched chick 


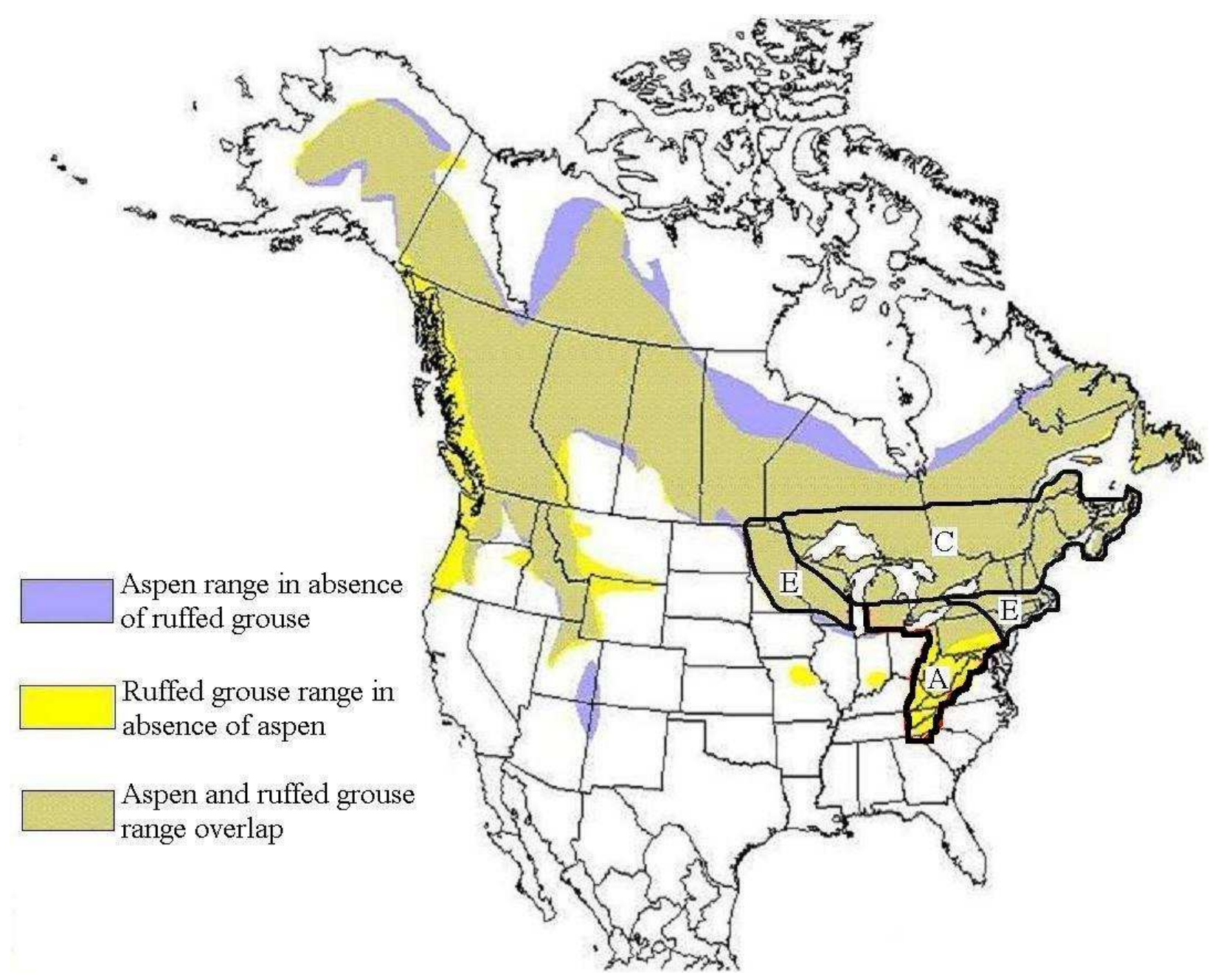

Figure 1.1. Range and overlap of aspen (Populus spp.) and ruffed grouse (Bonasa umbellus) in North America. Range of ruffed grouse subspecies within northern range $(\mathrm{C}=$ Canadian $[B . u$. togata $], \mathrm{E}=$ eastern $[$ B. u. umbellus $])$ and the Appalachian region $(\mathrm{A}=$ Appalachian $[B . u$. monticola]). 


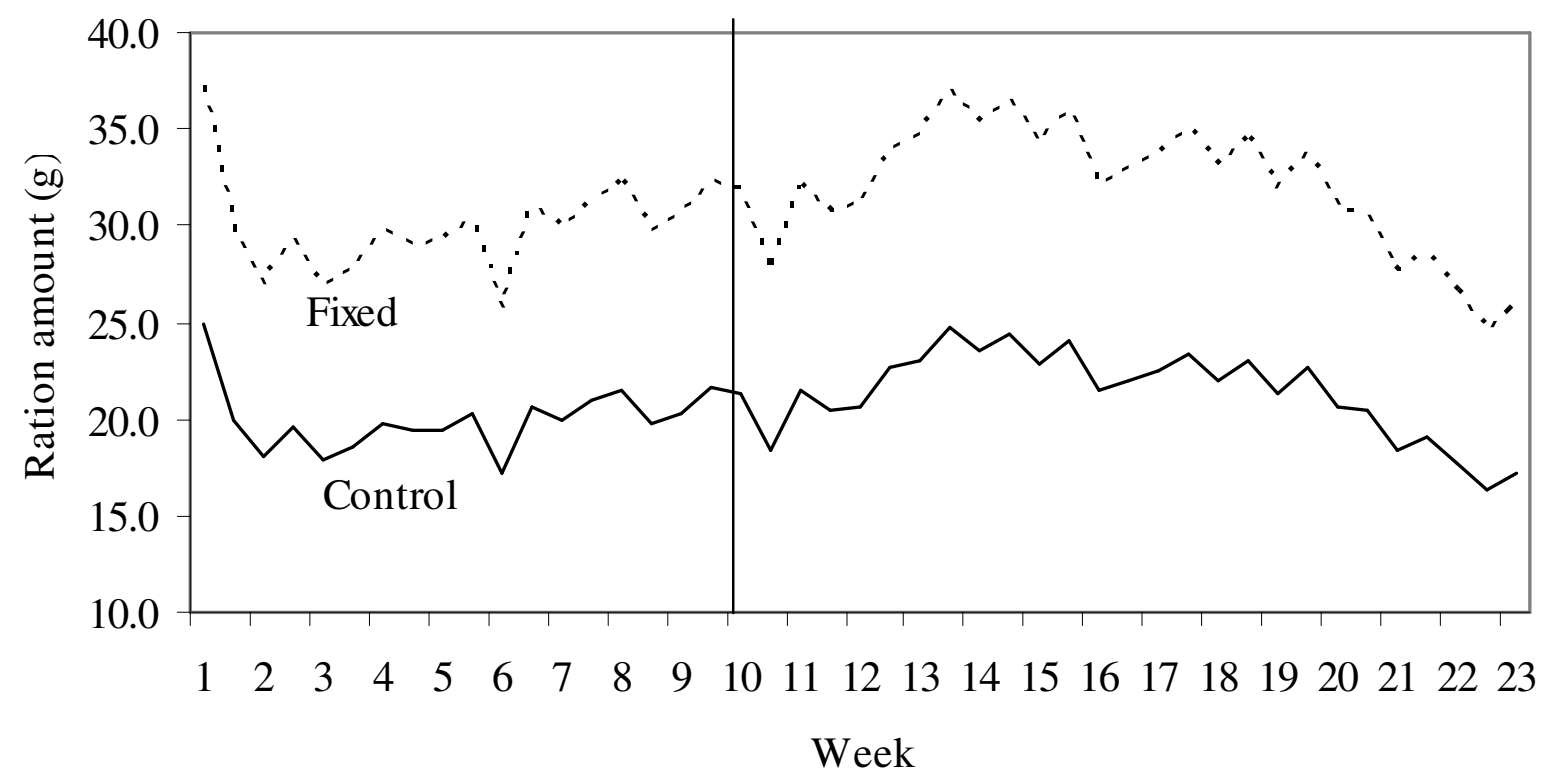

Figure 3.1. Mean daily feed intake of the control treatment group and amount fed to fixedtreatment groups (high-energy, low-protein; low-energy, high-protein; low-energy, mediumprotein) from February 1 until the termination of reproduction at West Virginia University's Animal Sciences Farm, 2004-2005. Vertical line denotes onset of laying in both years (approximately 10 weeks). 


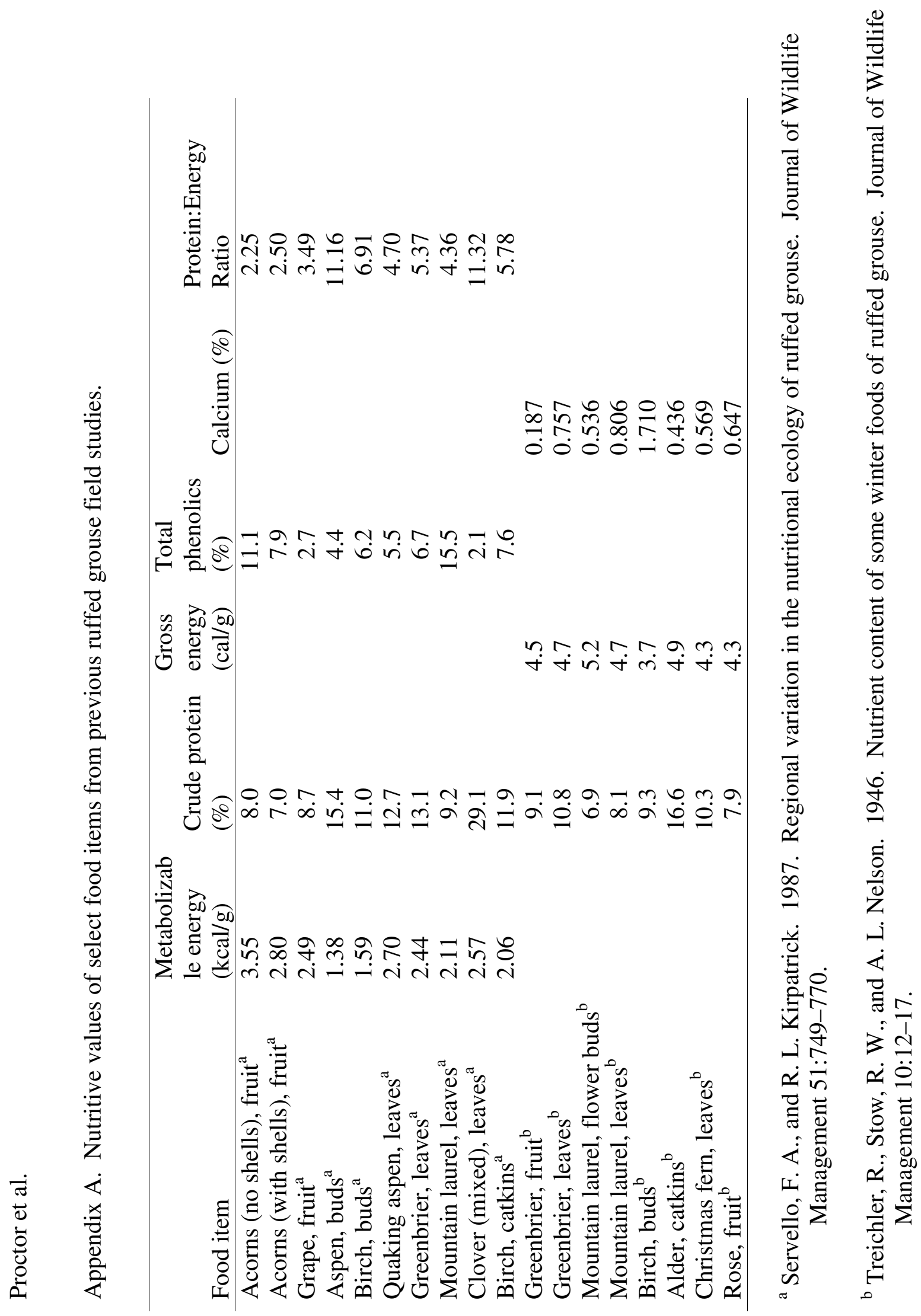


Appendix B. Cage layout and treatment assignments within the ruffed grouse facility for the 2004 and 2005 experiments. Cages are arranged in 4 rows, stacked top to bottom, 2 cages high and 12 across. Treatment rations are shown at the top of each block (HE-LP = High energy-low protein; LE-HP = Low energy-high protein; LE-MP = low energy-medium protein). $\mathrm{A}=$ adult female, $\mathrm{J}=$ juvenile female.

\begin{tabular}{|c|c|c|c|c|c|c|c|c|c|c|c|}
\hline \multicolumn{2}{|c|}{ Control } & & \multicolumn{2}{|c|}{ HE-LP } & & \multicolumn{2}{c|}{ LE-HP } & \multicolumn{2}{c|}{ LE-MP } & \\
\hline A & J & Male & A & J & Male & A & J & Male & A & J & Male \\
\hline A & J & Male & A & J & Male & A & J & Male & A & J & Male \\
\hline
\end{tabular}

\begin{tabular}{|c|c|c|c|c|c|c|c|c|c|c|c|}
\hline & \multicolumn{2}{|c|}{ HE-LP } & & \multicolumn{2}{c|}{ LE-HP } & & \multicolumn{2}{c|}{ LE-MP } & & \multicolumn{2}{|c|}{ Control } \\
\hline Male & J & A & Male & J & A & Male & J & A & Male & J & A \\
\hline Male & J & A & Male & J & A & Male & J & A & Male & J & A \\
\hline
\end{tabular}

\begin{tabular}{|c|c|c|c|c|c|c|c|c|c|c|c|}
\hline & \multicolumn{2}{|c|}{ LE-HP } & & \multicolumn{2}{c|}{ LE-MP } & & \multicolumn{2}{c|}{ Control } & & \multicolumn{2}{|c|}{ HE-LP } \\
\hline Male & A & J & Male & A & J & Male & A & J & Male & A & J \\
\hline Male & A & J & Male & A & J & Male & A & J & Male & A & J \\
\hline
\end{tabular}

\begin{tabular}{|c|c|c|c|c|c|c|c|c|c|c|c|}
\hline \multicolumn{2}{|c|}{ LE-LP } & & \multicolumn{2}{c|}{ Control } & & \multicolumn{2}{c|}{ HE-LP } & & \multicolumn{2}{|c|}{ LE-MP } & \\
\hline J & A & Male & J & A & Male & J & A & Male & J & A & Male \\
\hline J & A & Male & J & A & Male & J & A & Male & J & A & Male \\
\hline
\end{tabular}


Appendix C. Candidate models for estimating percent fat based on analysis of sacrificed grouse ( $n=16$ individuals). Data were fit using linear regression in SAS (PROC REG, SAS Institute Inc. 2002-2004).

\begin{tabular}{lcc}
\hline Model & $R^{2}$ (Adjusted) & $P$ \\
\hline 1) Percent fat $=$ Body mass & $\mathbf{0 . 6 5}(\mathbf{0 . 6 2})$ & $\leq \mathbf{0 . 0 0 1}$ \\
2) Percent fat $=$ TOBEC value & $0.12(0.05)$ & 0.197 \\
3) Percent fat $=$ Body mass + TOBEC value ${ }^{\mathbf{a}, \mathbf{b}}$ & $\mathbf{0 . 8 3}(\mathbf{0 . 8 1})$ & $\leq \mathbf{0 . 0 0 1}$ \\
\hline
\end{tabular}

${ }^{\text {a }}$ TOBEC adjusted partial $R^{2}=0.18$

${ }^{\mathrm{b}}$ Variance Inflation Factor for both independent parameters was 2.42. Condition indices for body mass and TOBEC were 15.84 and 29.07 , respectively 


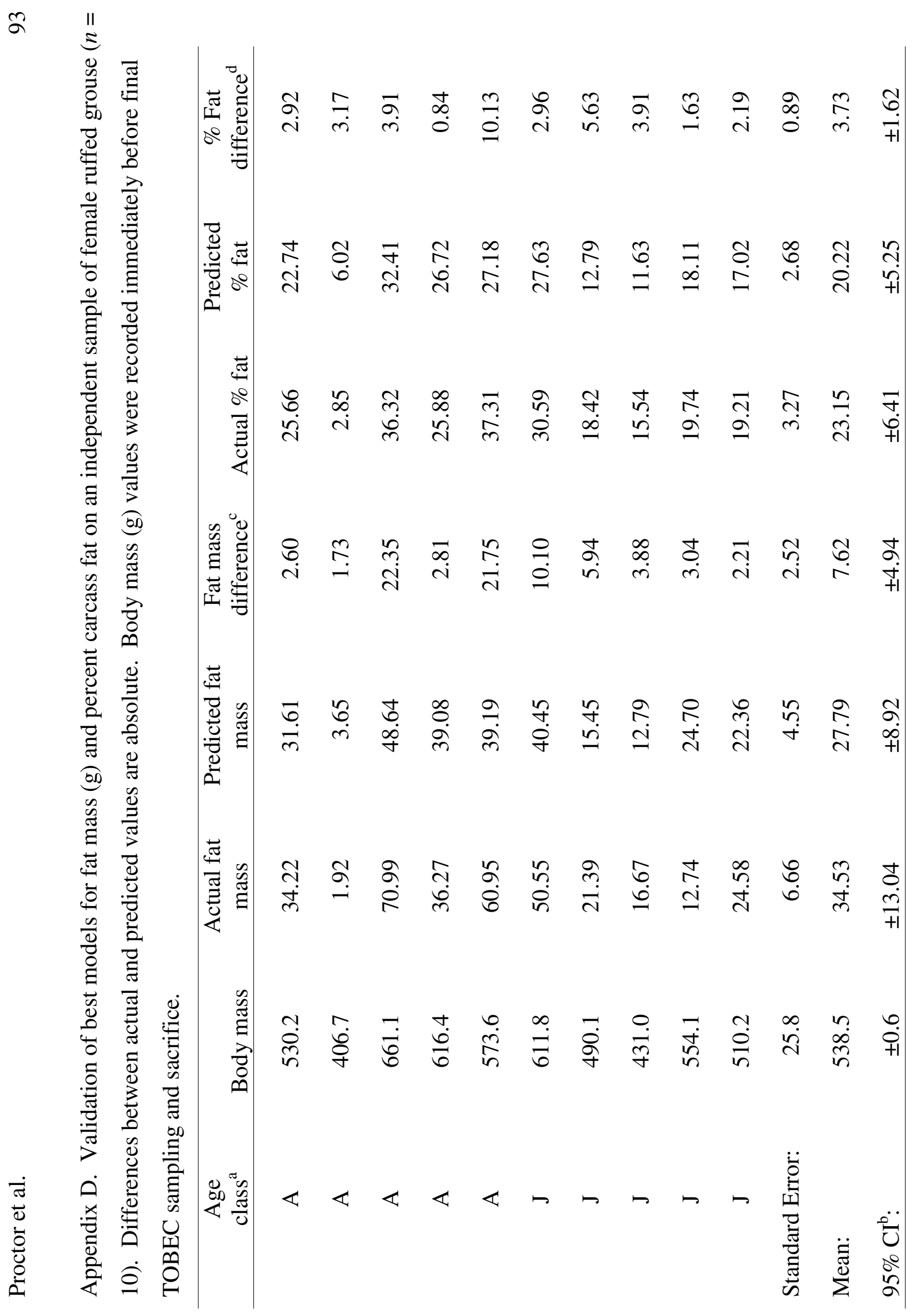




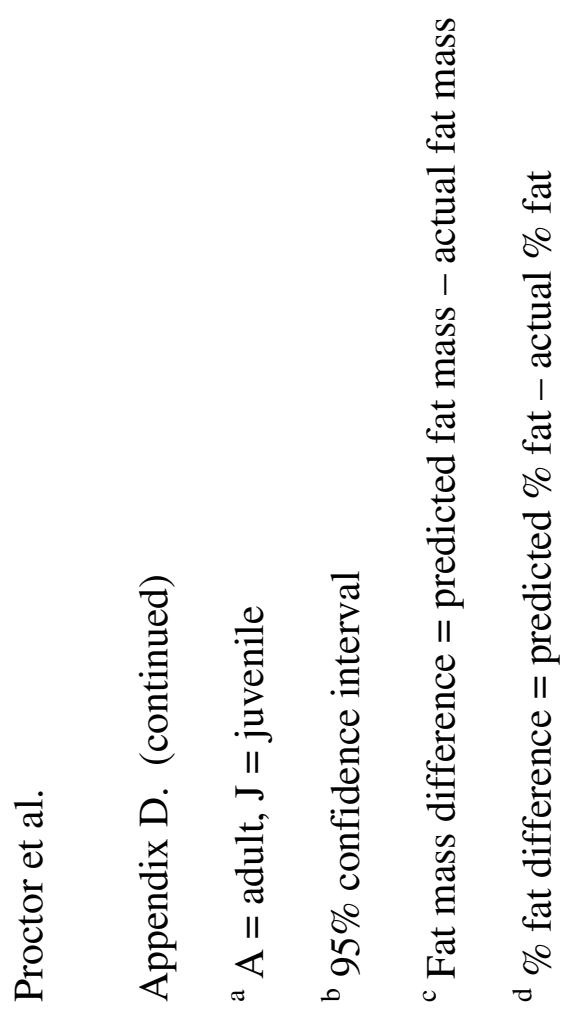




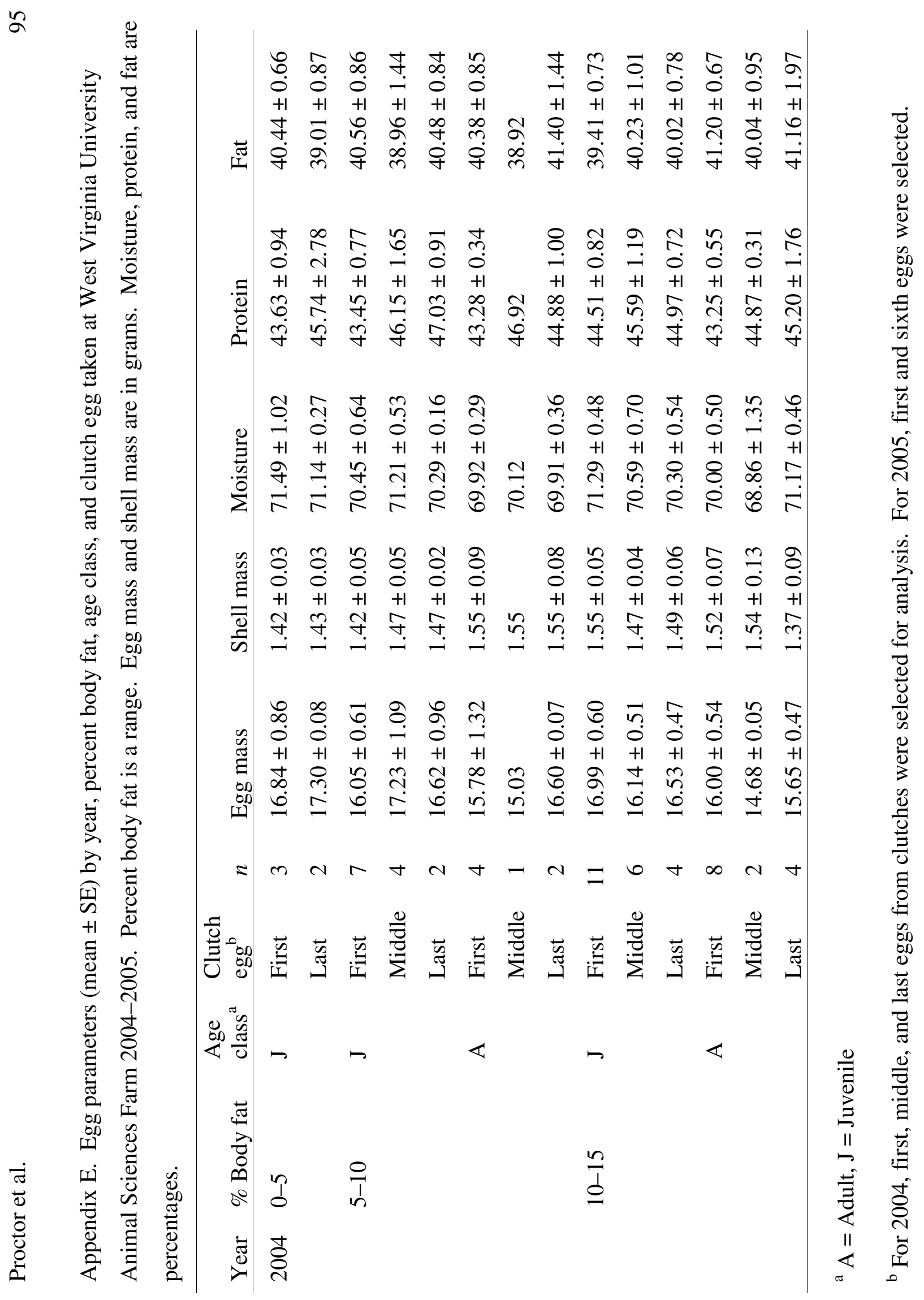




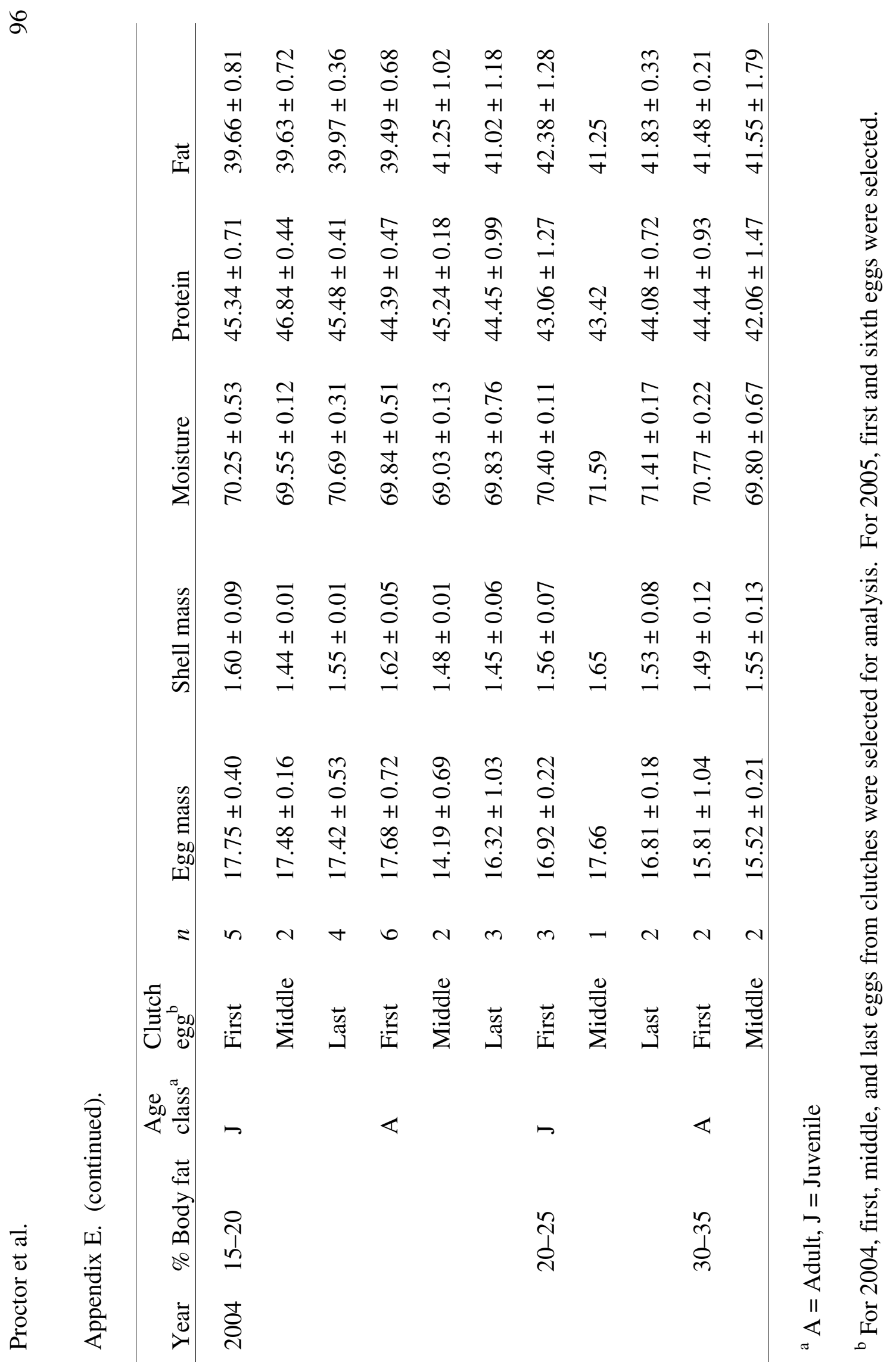




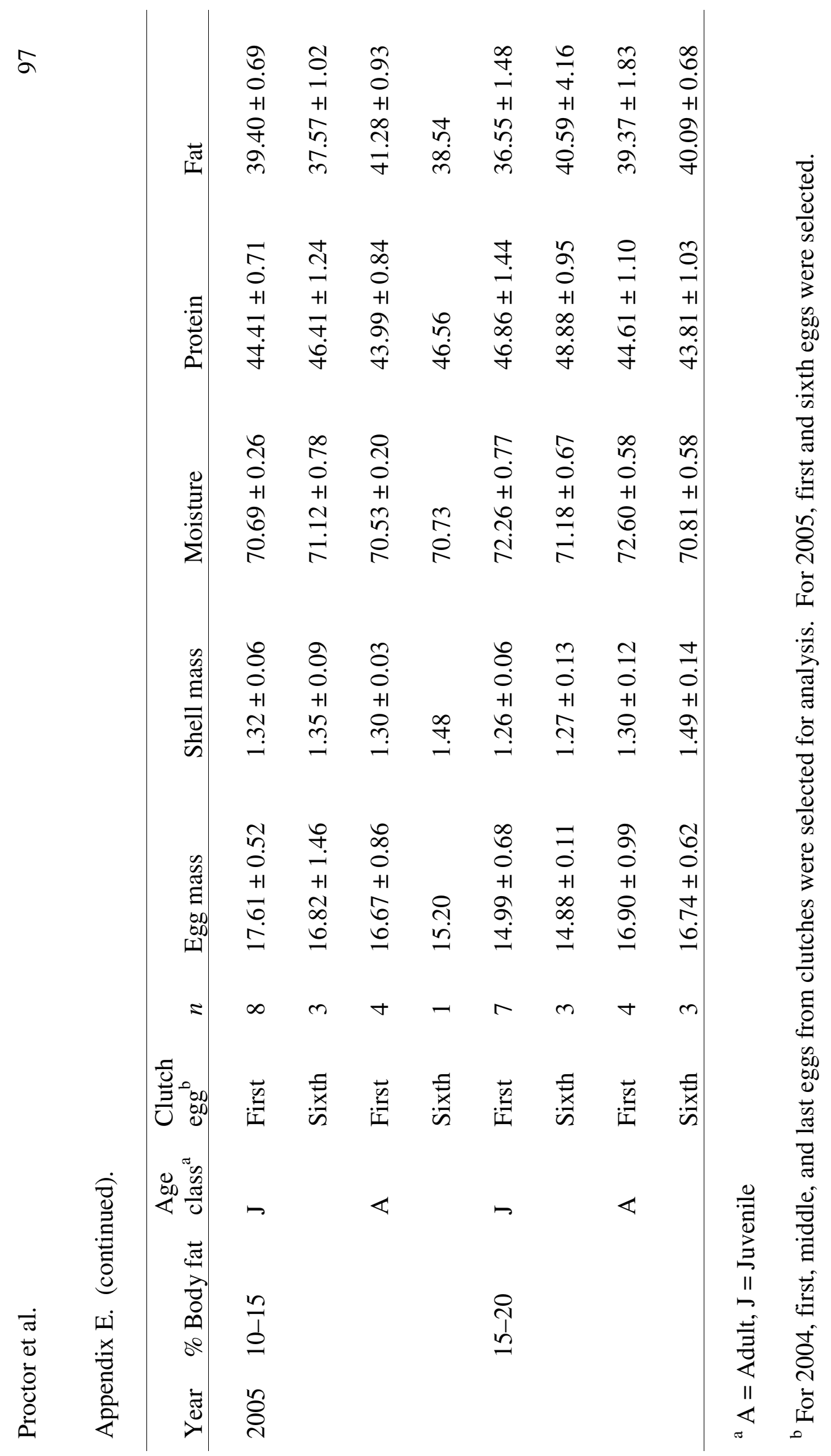




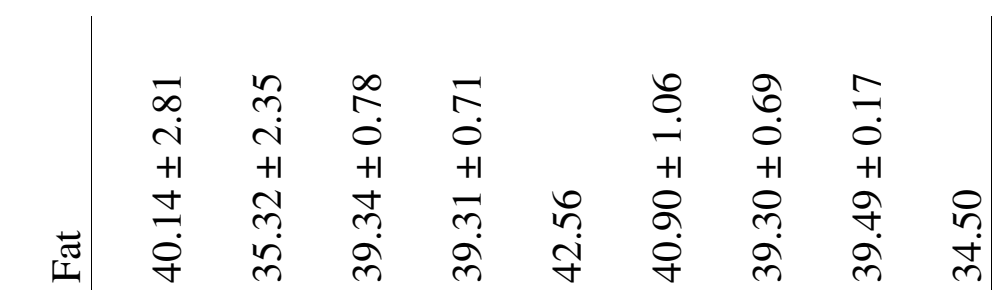

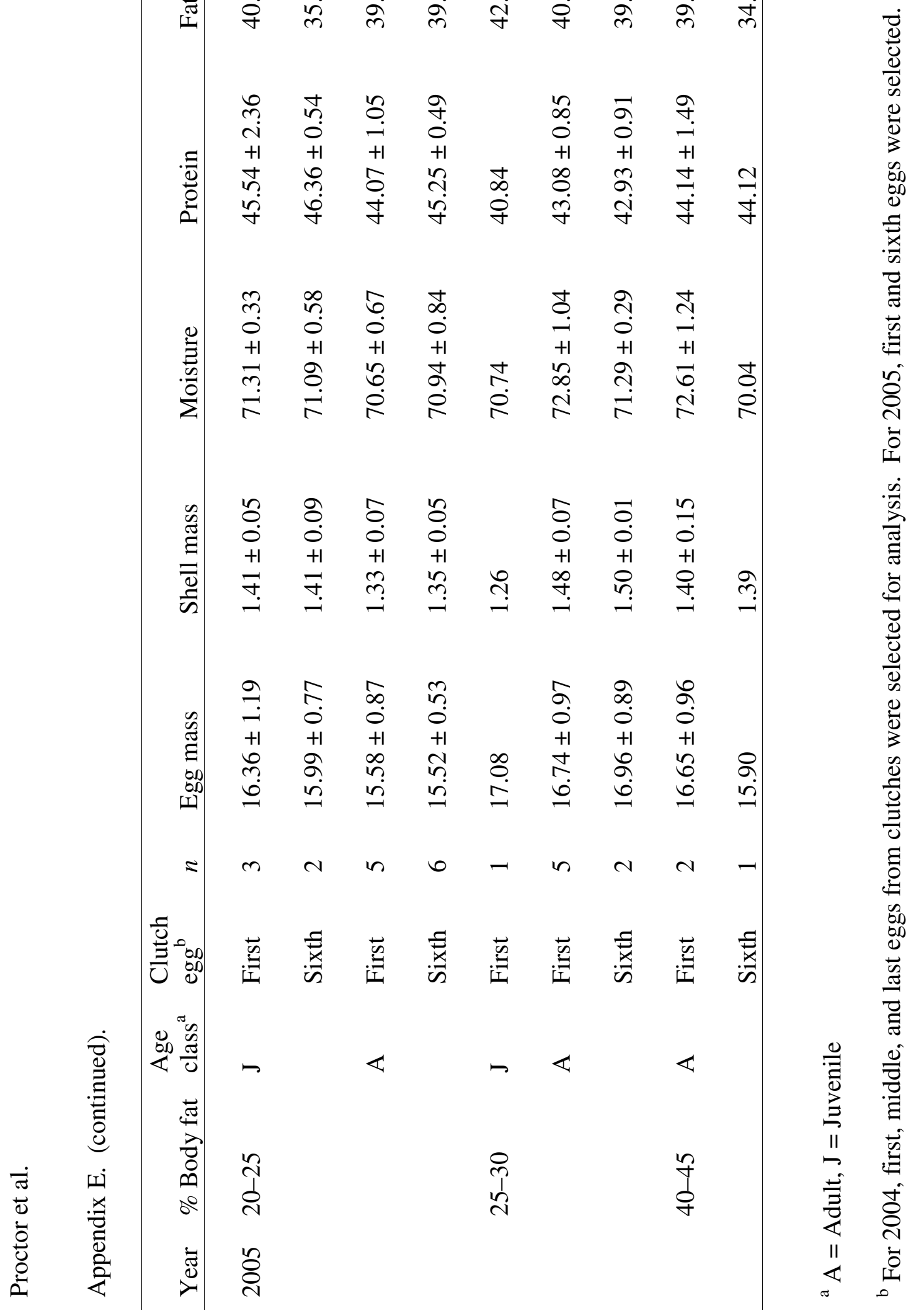




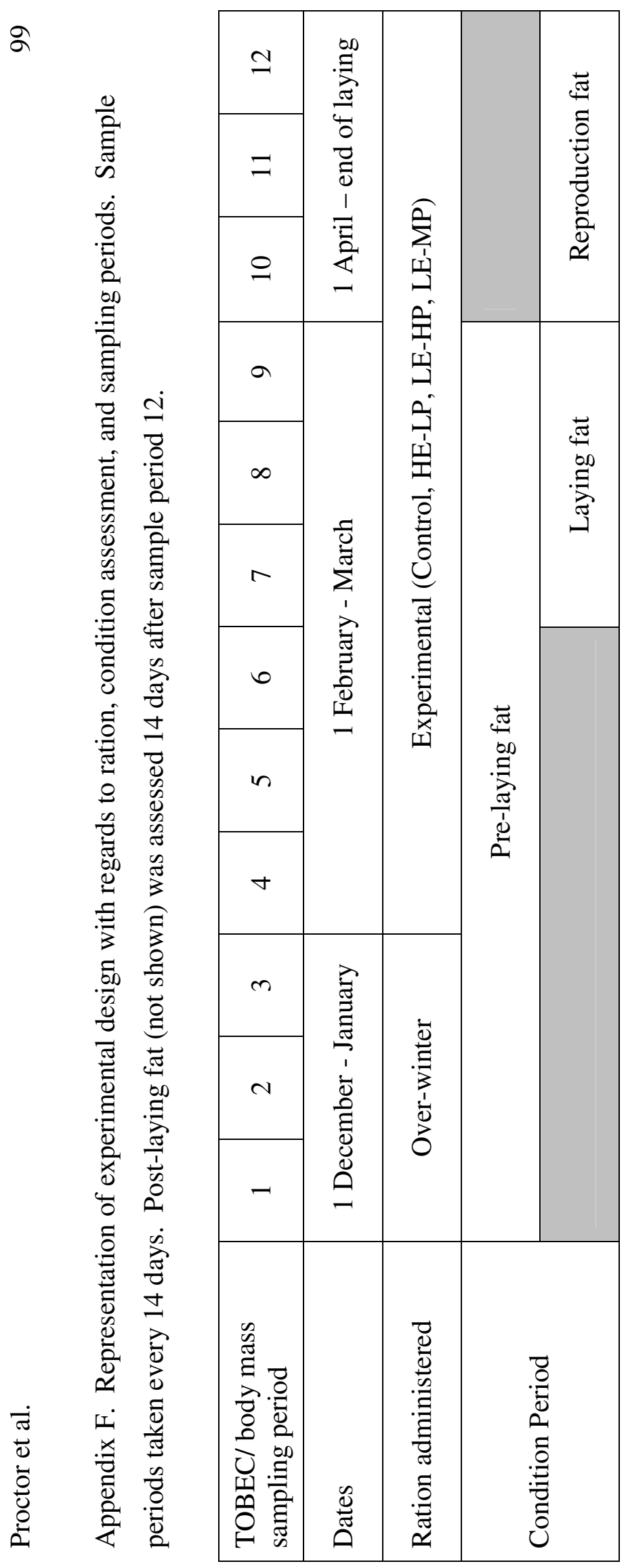

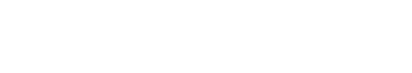

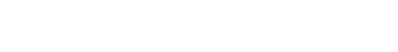

